\title{
Flora do Espírito Santo: Monimiaceae
}

\author{
Flora of Espírito Santo: Monimiaceae
}

\author{
Elton John de Lírio $^{1,2}$ \& Ariane Luna Peixoto ${ }^{1}$
}

\begin{abstract}
Resumo
Monimiaceae, uma família basal de Angiospermas, compreende 28 gêneros e aproximadamente 220 espécies que ocorrem predominantemente em florestas úmidas. No Brasil está representada por cinco gêneros e cerca de 43 espécies. A Mata Atlântica é considerada um dos centros de diversidade da família e nela ocorrem os cinco gêneros representados no Brasil e a maior parte das espécies, muitas das quais endêmicas desse bioma. O presente estudo buscou conhecer e caracterizar as espécies de Monimiaceae ocorrentes no estado Espírito Santo. O estudo resultou na identificação e caracterização morfológica de 21 táxons pertencentes a três gêneros: Macroturus e Macropeplus com uma espécie cada e 19 para Mollinedia. O gênero Macropeplus é citado pela primeira vez para o estado, bem como Mollinedia puberula. É apresentada uma chave para identificação, descrições morfológicas, distribuição geográfica e comentários.

Palavras-chave: Laurales, Macropelus, Macrotorus, Mata Atlântica, Mollinedia.

Abstract

Monimiaceae, a basal angiosperm family, comprises 28 genera and approximately 220 species that inhabits predominantly rainforests. In Brazil, it is represented by five genera and about 43 species. The Atlantic forest is considered one of the centers of diversity of this family. In this biome occurs the five genera represented in Brazil, as well as most of the species, many of them endemic to this biome. The present study aims to characterize the species of Monimiaceae that occur in the state of Espírito Santo. The study resulted in the identification and morphological characterization of 21 taxa belonging to three genera: Macrotorus and Macropeplus, both with one species, and Mollinedia, with 19 species. Macropeplus is reported for first time to the state of Espírito Santo, as well as Mollinedia puberula. A key to identification, morphological descriptions, geographic distribution and comments are provided.
\end{abstract}

Key words: Laurales, Macropelus, Macrotorus, Atlantic Forest, Mollinedia.

\section{Introdução}

A família Monimiaceae (ordem Laurales) engloba 28 gêneros e cerca de 220 espécies (Renner et al. 2010). Com ocorrência predominantemente tropical, tem como seus principais centros de dispersão o Arquipélago Malaio e o sul-sudeste brasileiro (Peixoto \& Pereira-Moura 2008; Renner et al. 2010).

A família foi descrita por Jussieu em 1809 , tendo como gênero tipo Monimia. Era uma família de difícil delimitação e polifilética, englobando táxons que foram sendo desmembrados, constituindo famílias distintas, como Atherospermataceae
(Brown 1814), Trimeniaceae (Gibbs 1917), Amborellaceae (Pichon 1948) e Siparunaceae (Schodde 1970). Análises moleculares confirmaram o polifiletismo da família e a necessidade dos desmembramentos realizados e também a relação mais próxima de Monimiaceae com Hernandiaceae e Lauraceae, do que com os grupos anteriormente incluídos na família (Renner 1999). Como circunscrita atualmente Monimiaceae é monofilética (APG IV 2016). Monimiaceae é monofilética e subdividida em três subfamílias: Hortonioideae, Monimioideae e Mollinedioideae (Renner et al. 2010). Todas as espécies que ocorrem

\footnotetext{
${ }^{1}$ Instituto de Pesquisas Jardim Botânico do Rio de Janeiro, Escola Nacional de Botânica Tropical, Prog. Pós-graduação em Botânica, R. Pacheco Leão 2040, Solar da Imperatriz, Horto, 22460-030, Rio de Janeiro, RJ, Brasil.

${ }^{2}$ Autor para correspondência: lirioeltonj@gmail.com
} 
no Brasil pertencem a Mollinedioideae, uma subfamília pantropical que inclui aproximadamente 21 gêneros e 180 espécies (Philipson 1993; Renner et al. 2010).

No Brasil ocorrem cinco gêneros e cerca de 43 espécies da família distribuídas em todos os biomas (BFG 2015). Hennecartia omphalandra J.Poiss., monotípico, ocorre no sudeste e sul do Brasil (Peixoto et al. 2001); Grazielanthus arkeocarpus Peixoto \& Per.-Moura, monotípico, endêmico da floresta de baixada do trecho central do estado do Rio de Janeiro (Peixoto \& Pereira-Moura 2008); Macrotorus utriculatus (Mart. ex Tul.) Perkins, monotípico restrito à Floresta Atlântica, ocorre na Bahia, Espírito Santo, Rio de Janeiro e São Paulo (Lírio et al. 2015); Macropeplus Perkins com quatro espécies, que se distribuem nas cadeias montanhosas da Bahia, Minas Gerais, Goiás, Distrito Federal, Rio de Janeiro e São Paulo (Santos \& Peixoto 2001); e Mollinedia Ruiz \& Pav. com cerca de 40 espécies que ocorrem no sul do México, América Central, Antilhas e nos países da América do Sul, exceto na Argentina, Chile e Uruguai (Peixoto 1987; BFG 2015).

A Mata Atlântica é o bioma brasileiro que detêm maior número de táxons, com ocorrência de cinco gêneros e mais da metade das espécies conhecidas para o Brasil, das quais muitas são endêmicas de pequenas áreas (Peixoto \& Gonzalez 2009; Peixoto et al. 2013; BFG 2015).

O território do Espírito Santo totalmente inserido na Mata Atlântica, embora com apenas $11,07 \%$ de remanescentes naturais, é considerado um dos estados com maior riqueza de espécies no Brasil (Dutra et al. 2015), além de possuir o segundo maior recorde em riqueza de plantas lenhosas por hectare (Thomaz \& Monteiro 1997; Saiter et al. 2011). É também uma área de destaque em riqueza de Monimiaceae no contexto do Brasil por abrigar três gêneros e 21 espécies dessa família: Macrotorus (1); Mollinedia (19) e Macropeplus (1), este último encontrado após indicações de um estudo de distribuição potencial do gênero que apontou adequabilidade ambiental de $15-32 \%$ para a espécie no sul do Espírito Santo (Gonzalez 2007).

Diante do exposto, o presente estudo buscou verificar a riqueza de Monimiaceae no território capixaba, a ocorrência do gênero Macropeplus, caracterizar os táxons através de morfologia, ilustrações e fotografias, fornecer chave de identificação, mapas de distribuição geográfica e comentários para os gêneros e espécies.

\section{Material e Métodos}

O Espírito Santo, localizado na região sudeste do Brasil, possui extensão aproximada de $44.000 \mathrm{~km}^{2}$, está totalmente inserido no bioma Mata Atlântica. Apresenta uma grande variação de fatores abióticos, o que lhe confere uma considerável variação de habitats. A altitude varia desde o nível do mar até 2892 m, as áreas vão de planas a acidentadas, secas a encharcadas, com solos rasos, medianos ou profundos podendo se apresentar pedregoso ou não, sob influência direta do mar ou não (Lani et al. 2008). Três formações geomorfológicas são conhecidas para o estado, que sustentam tipos de vegetação distintos: o Pré-Cambriano, onde ocorre a Floresta Ombrófila Densa Floresta Estacional Semidecidual; o Tabuleiro Terciário, com as matas de tabuleiros, e a planície arenosa marinha Quaternária, com as formações pioneiras e predominância da restinga (Garbin et al. 2017). Nestas três formações geomorfológicas encontram-se 14, 5 e 8 Unidades de Conservação (federais e estaduais, exceto RPPNs), respectivamente, totalizando $2,62 \%$ do território do estado (IPEMA 2004).

$\mathrm{O}$ estudo foi baseado em coletas campo e material de herbário. As espécies já representadas nos acervos dos herbários foram recoletadas para análises da variação morfológica, ambiente de ocorrência e georreferenciamento. Foram visitados os municípios Alfredo Chaves, Afonso Cláudio, Anchieta, Aracruz, Atílio Vivacqua, Cariacica, Itarana, Laranja da Terra, Linhares, Santa Leopoldina, Santa Maria de Jetibá, São Roque do Canaã, Santa Teresa, São Mateus, Serra e Vargem Alta. As exsicatas foram depositadas no herbário do Instituto de Pesquisas Jardim Botânico do Rio de Janeiro (RB) com duplicatas para o Instituto Nacional da Mata Atlântica (MBML). Foram consultadas as coleções dos herbários sediados no Espírito Santo (CVRD, MBML e VIES), em Minas Gerais (VIC e BHCB), no Rio de Janeiro (R, RB e RBR) e São Paulo (SP, SPF e SPSF), acrônimos de acordo com Thiers (continuamente atualizado).

A identificação foi realizada utilizando-se chaves de identificação, literatura especializada (Tulasne 1857; Perkins 1900; Perkins \& Gilg 1901; Peixoto 1979; Peixoto 1987), comparação com exsicatas identificadas e com material tipo e fotografias de tipo disponíveis em bancos de dados virtuais de coleções científicas.

A descrição dos táxons, as chaves dicotômicas e as ilustrações foram elaboradas com base nos 
caracteres morfológicos observados nos espécimes examinados em campo e em material herborizado do Espírito Santo. Material adicional de outros estados foi utilizado apenas para complementar as descrições, quando necessário. A terminologia morfológica foi baseada em Radford et al. (1974), Willard (1978), Barroso et al. (1999), Stern (2004), Endress (2010) e Romanov et al. (2007). As medidas foram realizadas em material seco (exceto em flores, que foram hidratadas) com o uso de paquímetro. A coloração das folhas, caráter constante utilizado na chave e descrições das espécies, deve ser utilizado com cautela em espécimes herborizados com uso de álcool. Os mapas de ocorrência das espécies foram elaborados com base na planilha de ocorrência dos espécimes, os pontos foram plotados sobre escala altitudinal.

\section{Resultados e Discussão}

Foram registados 21 táxons da família Monimiaceae para o Espírito Santo pertencentes a três gêneros: Macroturus e Macropeplus com uma espécie cada e Mollinedia com 19 espécies, dentre elas, Macropeplus schwackeanus (Perkins) I.Santos \& Peixoto e Mollinedia puberula Perkins são reportados pela primeira vez para o estado; Mollinedia dolichotricha Lírio \& Peixoto foi recentemente descrita, enquanto que Mollinedia fruticulosa Perkins, Mollinedia micranta Perkins e Mollinedia stenophylla Perkins não foram registradas para o estado (Dutra et al. 2015; Lírio et al. 2017). Quando comparado à Lista do Brasil (BFG 2015) o presente trabalho acresce $24 \%$ no número de táxons em Monimiaceae (cinco espécies). Todas as espécies ocorrem na região serrana, em florestas de encosta montana; enquanto que nas florestas dos tabuleiros terciários ocorrem três espécies e nas florestas de restingas sobre terrenos quaternários, duas espécies. Mollinedia glabra (Spreng.) Perkins e Mollinedia sphaerantha Perkins ocorrem em florestas de restinga, em floresta de tabuleiro, e nas florestas de encostas, em terremos pré-cambrianos, a primeira tem preferência por florestas associadas a afloramentos rochosos ou arenosos, enquanto que a segunda por interior de mata. Macropeplus schwackeanus (Perkins) I.Santos \& Peixoto é a única espécie que ocorre em altitudes acima de $1200 \mathrm{~m}$.

\section{Monimiaceae}

Árvores ou arbustos, raramente escandentes, monóicas ou dióicas, aromáticas ou não. Ramos cilíndricos a subcilíndricos, ramos jovens com catáfilos na base, depois caducos. Folhas simples, opostas, margem inteira ou denteada, sem estípulas. Inflorescências em cimas trifloras isoladas ou reunidas em fascículos ou tirsos, ou reduzidas a flores solitárias, axilares ou terminais. Flores unissexuadas, monoperiantadas, tépalas 4; flores estaminadas com receptáculo plano, campanulado, cupuliforme ou urceolado, estames livres, poucos a numerosos, anteras rimosas, fendas longitudinais ou transversais, contínuas ou não; flores pistiladas com receptáculo cupuliforme, deiscência circuncisa, carpelos poucos a numeros, livres, presos à base do receptáculo, 1-ovular, óvulo pêndulo, anátropo. Frutos múltiplos, drupéolas livres, expostas desde cedo.

No Espírito Santo ocorrem três gêneros: Macrotorus Perkins e Macropeplus Perkins ambos com uma espécie e Mollinedia Ruiz \& Pav., com 19 espécies. Macrotorus se distingue por possuir flores com receptáculo longamente urceolado, bem maior que as tépalas (proporção de 1/9 a 1/14 do tamanho da flor), Macroepeplus possui tépalas maiores em relação ao receptáculo (até 4/5) enquanto que Mollinedia apresenta menor diferença na proporção receptáculo-tépalas (chegando a ca. 1/1). Os estames em Macrotorus são desiguais entre si, os apicais reniformes, com deiscência por fenda longitudinal contínua e os basais peltados com deiscência transversal. Em Macropeplus os estames são desiguais, sendo os apicais mais alongados, todos com deiscência longitudinal contínua. Em Mollinedia os estames são iguais ou desiguais, hipocrepiformes, ovados, oblongos ou elípticos, com fendas longitudinais contínuas ou não. Estes três gêneros constituem um grupo estreitamente relacionado.

\section{Chave de identificação das espécies de Monimiaceae}

1. Folhas glabras.

2. Flores brancas, tépalas com o dobro do comprimento do receptáculo ou mais..... 1.1. Macropeplus schwackeanus

2'. Flores amarelas, alaranjadas ou esverdeadas, tépalas com aproximadamente o mesmo comprimento do repcetáculo ou menores. 
3. Folhas pelúcido-pontuadas.

4. Arbustos ou arvoretas, folhas nítidas, papiráceas ou cartáceas (coriáceas somente em espécimes de afloramento rochoso); flores estaminadas com receptáculo urceolado

4'. Árvores, folhas opacas, nunca papiráceas ou cartáceas, flores estaminadas com receptáculo campanulado 3.19. Mollinedia sp. 3

3'. Folhas não pelúcido-pontuada.

5. Folhas enegrecidas quando secas; drupéolas pubérulas.

3.3. Mollinedia engleriana

5'. Folhas esverdeadas, oliváceas ou castanhas quando secas; drupéolas glabras.

6. Flores estaminadas com receptáculo longamente urceolado; anteras da base do receptáculo reniformes 2.1. Macrotorus utriculatus

6'. Flores estaminadas com receptáculo plano; anteras da base do receptáculo nunca reniformes.

7. Folhas oliváceas, base cuneada, nervuras secundárias 5-7 pares

3.10. Mollinedia oligantha

7'. Folhas castanhas, base aguda, nervuras secundárias 11-14 pares 3.18. Mollinedia sp. 2

1'. Folhas pilosas: vilosas, velutinas, seríceas, tomentosas, pubescentes ou pubérulas.

8. Folhas canescentes na face abaxial; flores exteriormente canescentes.

3.13. Mollinedia salicifolia

8'. Folhas nunca canescentes na face abaxial; flores nunca canescentes.

9. Folhas pubescentes ou pubérulas.

10. Folhas cartáceas, receptáculo das flores estaminadas campanulado, drupéolas ovadas, $0,8-0,9 \times$ ca. $0,6 \mathrm{~cm}$ 3.11. Mollinedia ovata

10'. Folhas rígido-cartáceas a coriáceas, receptáculo das flores estaminadas plano ou urceolado, drupéolas elípticas, maiores que $1,3 \times 0,8 \mathrm{~cm}$.

11. Folhas não pelúcido-pontuadas, pubérulas em toda a face abaxial; inflorescências ferrugíneo-tomentosas, flores estaminadas com receptáculo plano.

3.4. Mollinedia gilgiana

11'. Folhas pelúcido-pontuadas, pubérulas na face abaxial na metade inferior e na nervura central; inflorescências pubescentes, flores estaminadas com receptáculo urcerolado

3.15. Mollinedia sphaerantha

9'. Folhas seríceas, velutinas, vilosas ou tomentosas.

12. Folhas buladas ou semi-buladas, margem com linha contínua de tricomas.

13. Drupéolas enegrecidas, velutinas quando jovens, glabrescentes quando maduras; estames hipocrepiformes 3.9. Mollinedia marqueteana

13'. Drupéolas castanhas, velutinas; estames de dois formatos, interiores hipocrepiformes, mais externos ovados 3.7. Mollinedia lamprophylla

12'. Folhas nunca buladas, margem sem linha contínua de tricomas.

14. Folhas coriáceas, vilosas na face abaxial, anteras com lóculos não confluentes .... 3.6. Mollinedia glaziovii

14'. Folhas não coriáceas, não vilosas na face abaxial, anteras com lóculos confluentes.

15. Folhas com cicatrizes de tricomas espessadas, drupéolas nigrescentes quando secas 3.1. Mollinedia argyrogyna

15'. Folhas sem cicatrizes de tricomas espessadas, drupéolas não nigrescentes quando secas.

16. Folhas velutinas na face abaxial; drupéolas castanhas, velutinas 3.16. Mollinedia uleana

16'. Folhas nunca velutinas; drupéolas nunca castanhas e velutinas.

17. Ramos jovens e pecíolos com indumento ferrugíneos a castanho tomentoso. 
18. Folhas oblongas; estames basais com filetes curtos, estames apicais com filetes nulos....

18'. Folhas ovadas ou elípticas; estames com filetes nulos 3.14. Mollinedia schottiana

17'. Ramos jovens e pecíolos nunca ferrugíneos a castanho tomentosos.

19. Ramos com camada externa frequentemente desprendendo-se, folhas com tricomas patentes, alongados e hialinos, especialmente ao longo da nervura central....3.2. Mollinedia dolichotricha

19'. Ramos sem camada externa que se desprende, folhas com tricomas adpressos.

20. Folhas marrons quando secas; flores gríseo-seríceas, as estaminadas com receptáculo campanulado ..... 3.12. Mollinedia puberula

20’. Folhas oliváceas quando secas; flores alvo-pubérulas, as estaminadas com receptáculo plano. 3.17. Mollinedia sp. 1

1. Macropeplus Perkins, Bot. Jahrb. Syst. 25: 556, 1898 .

Árvores, dióicas, folhas opostas. Flores estaminadas brancas, em cimas trifloras, axilares ou extra-axilares, receptáculo campanulado, tépalas lanceoladas, estames ca. 18, distribuídos na parede do receptáculo, anteras com deiscência longitudinal, anteras apicais oblongas, com filetes, anteras basais ovadas, sésseis. Flores pistiladas solitárias, receptáculo campanulado, tépalas lanceoladas, deiscência circuncisa após a antese, em forma de caliptra, carpelos ca. 16, estilete alongado. Fruto múltiplo, livre, receptáculo reflexo, drupéolas cedo expostas, elípticas, glabras. Sementes com endosperma abundante e embrião apical, muito pequeno.

Gênero com quatro espécies, endêmico do Brasil, ocorre no Cerrado e na Mata Atlântica em elevações acima de ca. 1000 m (Santos \& Peixoto 2001; BFG 2015).

1.1. Macropeplus schwackeanus (Perkins) I.Santos \& Peixoto, Santos \& Peixoto, Rodriguésia 52: 97, 2001. Tipo: BRASIL. MINAS GERAIS: Ouro Preto, Itacolomy, fl. mas, Schwacke 7465 (RB! BHCB!).

Figs. 1h-k; 2a,b; 18a

Mollinedia ligustrina var. schwackeanus Perkins, Bot. Jahrb. Syst. 25: 559. 1898.

Árvores até $13 \mathrm{~m}$, dióicas, ramos cilíndricos, estriados, plantas glabras. Folhas elípticas, ápice agudo, base cuneada, margem inteira, raro 1-6 dentadas no terço superior, 5-6,5 × 1-2,8 cm, coriáceas, sem pontuações aparentes, quando secas enegrecidas na face adaxial, acinzentadas na abaxial; nervuras secundárias 6-9 pares, proeminentes na face abaxial, pecíolo com canalículo que pode se estender até a nervura central, 0,6-0,7 cm. Flores estaminadas brancas, em cimas trifloras, axilares ou extra-axilares, pedúnculo $1-1,3 \mathrm{~cm}$, brácteas ovadas, ápice agudo, ca. $1 \mathrm{~mm}$, caducas, pedicelo 0,3-0,4 $\mathrm{mm}$, bractéolas caducas, receptáculo campanulado, ca. $1 \mathrm{~cm}$ compr., 0,3-0,4 cm diâm., tépalas 3/4 do tamanho da flor, lanceoladas, ápice agudo, externas maiores, estames ca. 18, distribuídos na parede do receptáculo, anteras com deiscência longitudinal, anteras apicais oblongas, filetes longos, anteras basais ovadas, sésseis. Flores pistiladas brancas, solitárias, brácteas ca. $1 \mathrm{~mm}$, caducas, pedúnculo $0,7-1 \mathrm{~cm}$, bractéolas caducas, receptáculo campanulado, tépalas $3 / 4$ do tamanho da flor, lanceoladas, ápice agudo, externas maiores, carpelos ca. 16; ovários elíptico, estigma verrucoso, até $1 / 2$ do compr. do carpelo. Drupéolas elípticas $0,7-0,9 \times 0,5-0,7 \mathrm{~cm}$, estipitados, ápice arredondado, estigma persistente, pedúnculo e pedicelo juntos ca. $2,2 \mathrm{~cm}$, receptáculo frutífero ca. 0,6 cm diâm.

Material selecionado: Ibitirama, Santa Marta, Parque Nacional do Caparaó, parcela 8, ind. 204, 13.IX.2015, fl. mas, Araújo 444 (VIES, RB); parcela 8, ind. 573, 18.XII.2015, fr., Araújo 445 (VIES, RB).

Material adicional examinado: MINAS GERAIS: Ouro Preto, Serra de Ouro Preto, II.1894, fr., Schwacke (RB 42511), fl. fem, Schwacke 12353 (RB).

Endêmica da Mata Atlântica, era conhecida somente de poucos exemplares para Minas Gerais, no presente trabalho sua distribuição é extentida para o Espírito Santo, onde foi coletada no município de Ibitirama. Ocorre em uma UC: no Parque Nacional do Caparaó.

Diferencia-se das demais espécies pelas flores estaminadas e pistiladas brancas com tépalas alongadas, lanceolados, flores estaminadas em cimas trifloras, axilares ou extra-axilares, anteras com deiscência longitudinal, as apicais oblongas, com filetes longos, as basais ovadas, sésseis. Coletada com flores em setembro e frutos jovens em dezembro. 


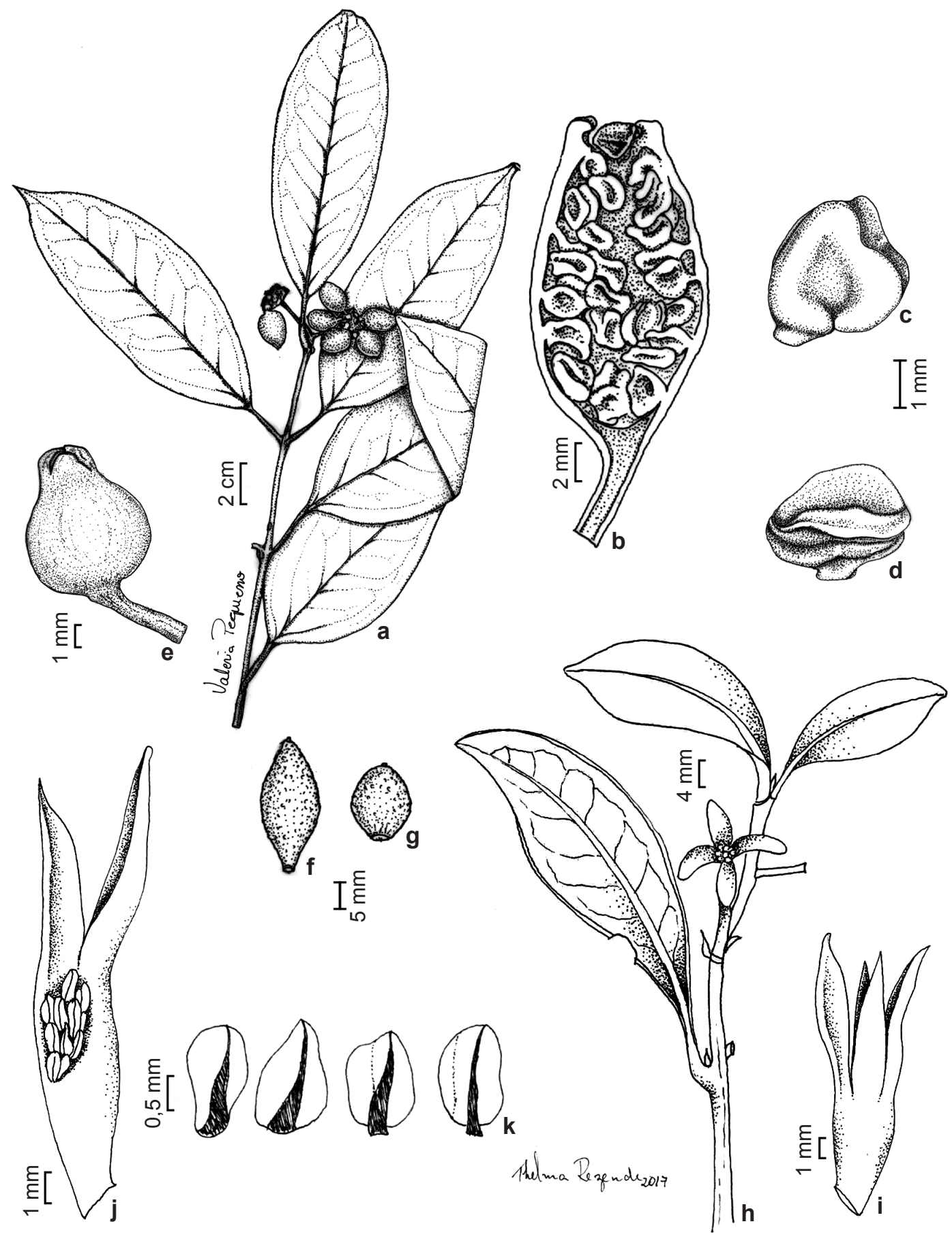

Figura 1 - a-g. Macrotorus utriculatus - a. ramo com frutos; b. flor estaminada em corte longitudinal exibindo os estames; c. estame hipocrepiforme; d. estame peltado; e. flor pistilada; f,g. formatos de drupéolas. h-k. Macropeplus schwackeanus - h. ramo com flor estaminada; i. flor estaminada; j. flor estaminada dissecada; $\mathrm{k}$. estames, a esquerda basais, a direita apicais. (a. Demuner 2828; d. Vervloet 477; e. Magnago 1150; f,g. Demuner 2436, 2828). Ilustrações: a-g. Valéria Pequeno; h-k. Thelma Rezende.

Figure 1 - a-g. Macrotorus utriculatus - a. branch with fruits; b. staminate flower in longitudinal section showing the stamens; c. estame hipocrepiform stamen; d. peltate stamen; e. pistillate flower; f,g. drupe shapes. h-k. Macropeplus schwackeanus - h. branch with staminate flowers; i. staminate flower; j. dissected staminate flower; k. stamens, left basal, right apical. (a. Demuner 2828; d. Vervloet 477; e. Magnago 1150; f,g. Demuner 2436, 2828). Illustrations: a-g. Valéria Pequeno; h-k. Thelma Rezende. 

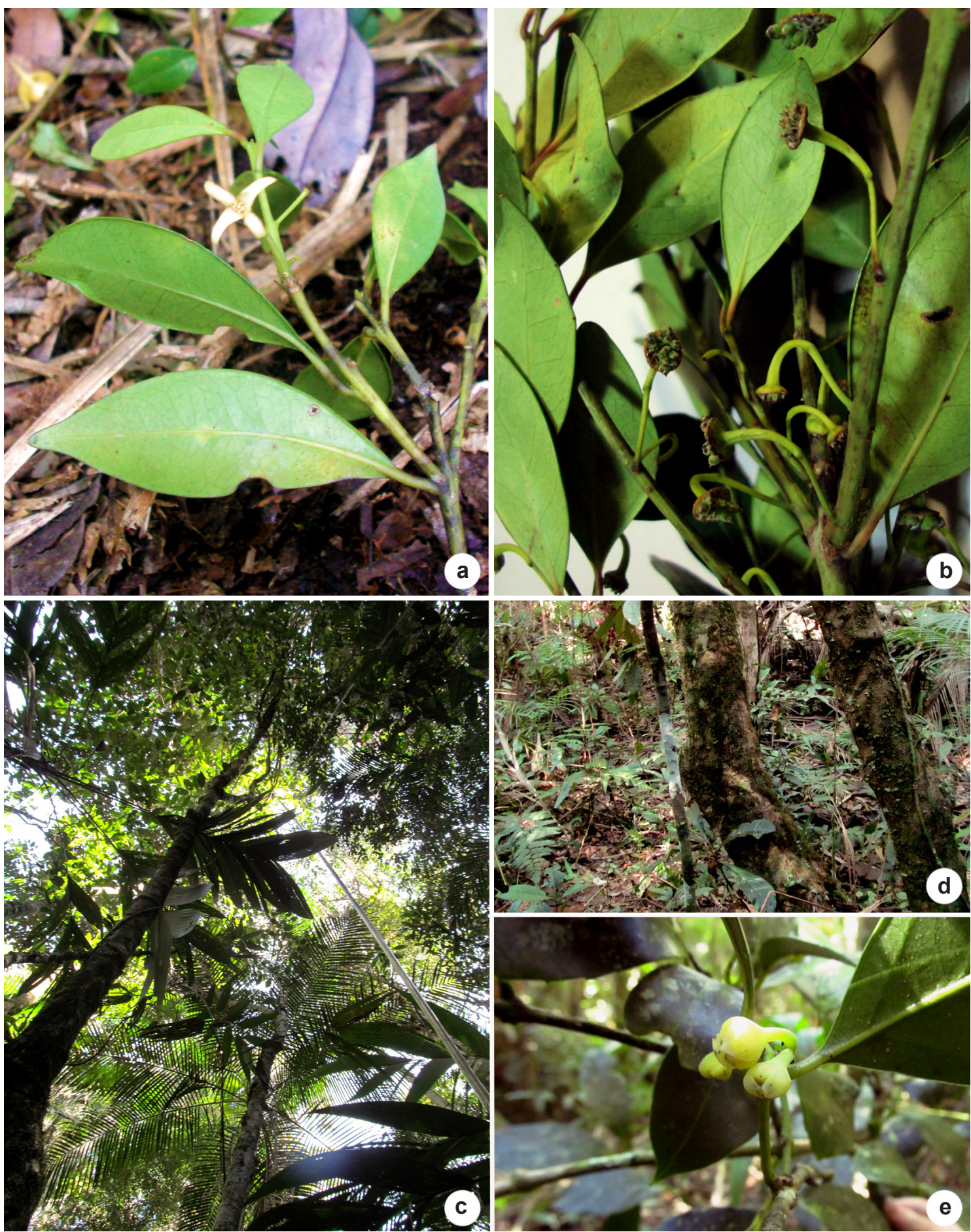

Figura 2 - a,b. Macropeplus schwackeanus - a. espécime com flor estaminada; b. espécime com frutos imaturos. c-e. Mollinedia engleriana - c. hábito; d. tronco; e. ramo com flores estaminadas em antese. (a. Araújo 444; b. Araújo 445; e. Lírio 190). Fotos: a,b. E.A. Araújo; c-e. V. Sarnaglia.

Figure 2 - a,b. Macropeplus schwackeanus - a. branch with staminate flower; b. branch with immature fruits. c-e. Mollinedia engleriana - c. habit; d. stem; e. branch with staminate flowers in anthesis. (a. Araújo 444; b. Araújo 445; e. Lírio 190). Photos: a,b. E.A. Araújo; c-e. V. Sarnaglia. 
2. Macrotorus Perkins, Bot. Jahrb. Syst. 25: 561, 1898.

Arbustos ou arvoretas, dióicos, folhas opostas. Flores estaminadas em cimas trifloras ou tirsos de 2(-4) cimas, receptáculo longamente urceolado, tépalas curtas; estames 28-54(-72), distribuídos na parede do receptáculo, anteras da base do receptáculo reniformes, deiscência longitudinal, anteras apicais circulares, deiscentes por fenda transversal contínua. Flores pistiladas solitárias, raro em tirsos 3-floros, receptáculo cupuliforme, tépalas com deiscência circuncisa após a antese, em forma de caliptra; carpelos (7-12)23-29; estilete alongado. Fruto múltiplo, livre, receptáculo reflexo, drupéolas cedo expostas, elípticas, glabras. Sementes com endosperma abundante e embrião apical, muito pequeno.

Gênero monotípico, endêmico da Mata Atlântica (BFG 2015; Lírio et al. 2015).

2.1. Macrotorus utriculatus (Mart. ex Tul.) Perkins, Bot. Jahrb. Syst. 25: 561, 1898. Tipo: BRASIL. RIO DE JANEIRO: "Macahé prov. Sebastianopolitanae", IX.1835, fl. mas, Luschnath s.n. (BR529634! P80306!).

Mollinedia utriculata Mart. ex Tul., Fl. bras. 4(1): 319, 1857.

Figs. 1a-g; 18a

Arbustos ou arvoretas até $6 \mathrm{~m}$ alt., ramos cilíndricos, estriados, plantas glabras. Folhas oblongas ou elípticas, ápice acuminado, base cuneada, margem inteira, raro 2-4 dentadas no terço superior, 8,1-18,3 × 3-5,7 cm, cartáceas a coriáceas, sem pontuações aparentes, verde-escuras na face adaxial, mais claras na abaxial, quando secas oliváceas, nítidas; nervuras secundárias 11-15 pares, proeminentes na face abaxial; pecíolo com canalículo que pode se estender até a nervura central, 1-2,5 cm. Flores estaminadas amarelas, em cima triflora ou tirsos de $2(-4)$ cimas, axilares ou terminais, raque $0-0,4 \mathrm{~cm}$, pedúnculo $0,5-3,6$ $\mathrm{cm}$, brácteas ovadas, ápice agudo, 0,7-1,2 $\mathrm{mm}$, pedicelo $0,7-1,2 \mathrm{~cm}$, bractéolas ovadas, ápice agudo, 1,2-1,5 mm; receptáculo longo-urceolado, 1,4-2 cm compr., $0,6-0,8 \mathrm{~cm}$ diâm., tépalas $1 / 9$ a $1 / 14$ do compr. da flor, ovadas, externas com ápice arredondado, margem irregular, internas com ápice truncado, desiguais, uma com margem dentada, outra com margem inteira; estames 48-54, filetes curtos, anteras da base do receptáculo reniformes, apicais circulares, deiscentes por fenda transversal contínua. Flores pistiladas amarelas, solitárias, raro em tirsos 3-floros, raque $0,1-0,2 \mathrm{~cm}$, pedúnculo 1,1-1,3 cm, brácteas ovadas, ápice agudo, ca. 2 $\mathrm{mm}$, pedicelo 1,6-2 cm, bractéolas ovadas, ápice agudo, ca. 1,7 mm, receptáculo campanulado, $0,6-0,8 \mathrm{~cm}$ compr., $0,5-0,6 \mathrm{~cm}$ diâm., tépalas $1 / 4$ do comprimento da flor, tépalas ovadas com ápice agudo, internas com apêndice muito curto arredondado; carpelos 23-29,3 mm compr., ovário elíptico, estigma verrucoso, até $1 / 2$ do compr. do carpelo. Drupéolas elípticas, 2,5-3 × 1,2-1,3 cm, estipitadas, ápice agudo ou arredondado, estigma persistente, quando maduras vináceas, quando secas oliváceas ou castanhas, pericarpo rígido e rugoso, pedúnculo e pedicelo juntos $1,9-3,6 \mathrm{~cm}$, receptáculo frutífero $0,7-1,6 \mathrm{~cm}$ diâm.

Material selecionado: Águia Branca, Águas Claras, propr. Seu Voito, 27.VII.2006, fl. fem, Magnago 1150 (MBML, RB). Cariacica, Reserva Biológica Duas Bocas, Alegre, trilha do Pau Oco, 15.II.2008, fr., Fraga 1849 (RB, MBML). Santa Teresa, Dois Pinheiros, Mata do Banestes, 22.VI.1999, fl. mas, Kollmann 2646 (MBML, RB).

Endêmica da Mata Atlântica, ocorre nos estados da Bahia, Espírito Santo, Rio de Janeiro e São Paulo (BFG 2015; Lírio et al. 2015). No Espírito Santo foi coletada em florestas de encosta em cinco municípios (Águia Branca, Cariacica, Marilândia, Santa Leopoldina, Santa Teresa, Serra e Vitória) e em Floresta de Tabuleiro (Conceição da Barra). Ocorre em quatro UCs: em Cariacica na Reserva Biológica Duas Bocas; em Santa Teresa, na Reserva Biológica Augusto Ruschi e na Mata do Banestes, e em Conceição da Barra na Reserva Biológica Córrego do Veado.

Diferencia-se das demais espécies pelas flores estaminadas com receptáculo longamente urceolado, tépalas $1 / 9$ a $1 / 14$ do comprimento da flor, e estames apicais reniformes, com deiscência por fenda longitudinal contínua e basais peltados com deiscência circuncisa. As folhas em campo usualmente tem odor que lembra o gênero Eucaliptus (Myrtaceae). O número de estames nos espécimes do Espírito Santo é variável quando comparado a populações de outros estados. A população de Ubatatuba (SP) possui 54-72 estames, as de Santos (SP) e Rio de Janeiro (RJ) possuem 28-32 estames (Peixoto et al. 2002), enquanto no Espírito Santo foram encontrados 48-54 estames. Coletada com flores de julho a setembro e frutos de janeiro a novembro.

3. Mollinedia Ruiz \& Pav., Fl. Peruv. Prodr. 83, 1794.

Árvores ou arbustos, dióicos ou monóicos, folhas opostas. Flores estaminadas em cimas trifloras, tirsos ou fascículos de cimas, axilares ou terminais, receptáculo plano, campanulado, 
cupuliforme ou urceolado, tépalas internas com apêndice inflexo ou não; estames 9-84, distribuídos irregularmente no receptáculo, filetes nulos ou curtos, anteras hipocrepiformes, ovadas, elípticas ou oblongas, deiscentes por fenda longitudinal contínua ou não. Flores pistiladas solitárias por redução da inflorescência ou em tirsos ou fascículos paucifloros, receptáculo cupuliforme, tépalas com deiscência circuncisa após a antese, em forma de caliptra; carpelos 5-65, estilete verrucoso, óvulo anátropo, pêndulo. Fruto múltiplo, livre, drupéolas cedo expostas, lisas, rugosas ou ásperas, glabras ou com indumento variado. Semente com endosperma abundante, embrião apical, muito pequeno.

Mollinedia é o gênero neotropical da família com maior número de espécies e distribuição mais ampla. Ocorre no sul do México, América Central e América do Sul, exceto Argentina, Chile e Uruguai.

3.1. Mollinedia argyrogyna Perkins, Bot. Jahrb. 27: 661, 1900. Tipo: BRASIL. RIO DE JANEIRO: Teresópolis, Serra dos Orgãos, 9.X.1867, fr., Glaziou 1591 (BR! B destruído). $\quad$ Figs. 3a,b; 18a

Árvores ou arvoretas com 5-20 m, dióicas, ramos subcilíndricos, jovens tomentosos, depois glabrescentes. Folhas elípticas, ápice agudo ou atenuado, base aguda ou cuneada, margem inteira ou com 1-3 pares de dentes irregulares, 5,1-14,2 $\times 1,7-4,3 \mathrm{~cm}$, cartáceas, discolores, quando secas amareladas na face adaxial e castanhas na face abaxial, glabrescentes e pontuadas pelas cicatrizes espessadas de tricomas na face adaxial, tomentosas na face abaxial, nervuras secundárias 4-7 pares proeminentes na face abaxial; pecíolo canaliculado, 0,4-1,5 cm. Flores estaminadas amareladas, em tirsos de até 6 cimas trifloras, axilares ou terminais, flavescente-tomentosas, raque $0,1-1,9$ $\mathrm{cm}$, pedúnculo $0,2-2,1 \mathrm{~cm}$, brácteas ovadas, ápice agudo, ca. $4 \mathrm{~mm}$, pedicelo 0,5-1,5 cm, bractéolas ovadas, ápice agudo, ca. $2 \mathrm{~mm}$; receptáculo campalunado, 0,3-0,7 cm compr., 0,4-0,6 cm diâm., tépalas $1 / 2$ do compr. da flor, ovados, externas com ápice arredondado, margem irregular, internas inflexas, ápice truncado, desiguais, uma com margem irregular, outra com margem denteada; estames 13-29, anteras hipocrepiformes, deiscentes por fenda longitudinal contínua, filetes nulos. Flores pistiladas amareladas, solitárias ou em fascículos de até 4 flores, argíreo-flavescentetomentosas, raque nula, pedúnculo $0-0,3 \mathrm{~cm}$, brácteas ovadas, ápice agudo, ca. $5 \mathrm{~mm}$, pedicelo 0,4-0,6 cm, bractéolas ovadas, ápice agudo, ca. 1,6 mm, receptáculo campanulado, internamente argíreo-flavescente-velutino, 0,4-0,5 cm compr., ca. 0,4 cm diâm., tépalas ovadas, externas mais alongadas, ápice arredondado, internas com ápice truncado, carpelos sésseis, 5-25, 0,18-0,2 mm compr., ovário oblongo, estigma $1 / 3$ a 1/4 do compr. do carpelo. Drupéolas elípticas, 1,9-2,6 × 1,2-1,4 $\mathrm{cm}$, ápice agudo, estilete persistente, estipitadas, roxas na maturação, negras quando secas, rugosas, tomentosas a glabrescentes, pedúnculo e pedicelo juntos $0,8-1,6 \mathrm{~cm}$, receptáculo frutífero $0,4-1,4$ cm diâm.

Material selecionado: Conceição do Castelo, Alto Bananal, 10.X.1985, fl. mas, Hatschbach 49932 (RB). Santa Teresa, Aparecidinha, terreno de L. Bringhenti, 16.VI.1999, fr., Kollmann 2595 (MBML, RB).

Material adicional examinado: BRASIL. RIO DE JANEIRO: Paraty, Km 206 da Estrada Rio-Santos, lado direito do sítio Canela Amarela (APA-Cairuçu), 17.V.1990, fl. fem, Klein 925 (RB).

Ocorre no Cerrado e na Mata Atlântica, nos estados do Espírito Santo, Minas Gerais, Rio de Janeiro, São Paulo e Paraná (BFG 2015). Tem sido coletada com mais frequência em matas estacionais. No Espírito Santo é conhecida apenas de coletas em floresta ombrófila densa, nos municípios de Conceição do Castelo e Santa Teresa. Não há registro de coleta da espécie em UCs capixabas.

Mollinedia argyrogyna se distingue pelas folhas quase sempre inteiras, ápice agudo e com pontuações na face adaxial, decorrente de cicatrizes espessadas da queda de tricomas. Pela pilosidade das folhas e formato dos frutos assemelha-se a $M$. lamprophylla e $M$. marqueteana das quais difere pelas folhas cartáceas e não buladas e 1,7-4,3 $\mathrm{cm}$ de largura (versus folhas coriáceas, buladas, nervuras secundárias 5,1-12,7 cm de largura em M. lamprophylla e $M$. marqueteana). Coletada com flores de outubro a dezembro e frutos de novembro a janeiro, março, junho e setembro.

3.2. Mollinedia dolichotricha Lírio \& Peixoto, Phytotaxa 239(1): 89, 2015. Tipo: BRASIL. ESPÍRITO SANTO: Santa Teresa, Estação Biológica Santa Lúcia, 17.VIII.2011, Lírio \& Aledi 39 (RB! MBML!).

Figs. 3c-h; 18b

Árvores 5-14 m alt., dióicas, tronco com diâmetro a altura do peito $8-18,5 \mathrm{~cm}$, ramos cilíndricos, castanho-escuros a amarronzados, longitudinalmente estriados, com camada externa muitas vezes desprendendo-se, esparsamente pilosos, catáfilos na base de ramos folhosos triangular-alongados, basais $3-5 \times 2-3 \mathrm{~mm}$, distais $3-6,5 \times 2-3,5 \mathrm{~mm}$, glabros na parte ventral e glabros ou pilosos na dorsal; tricomas 

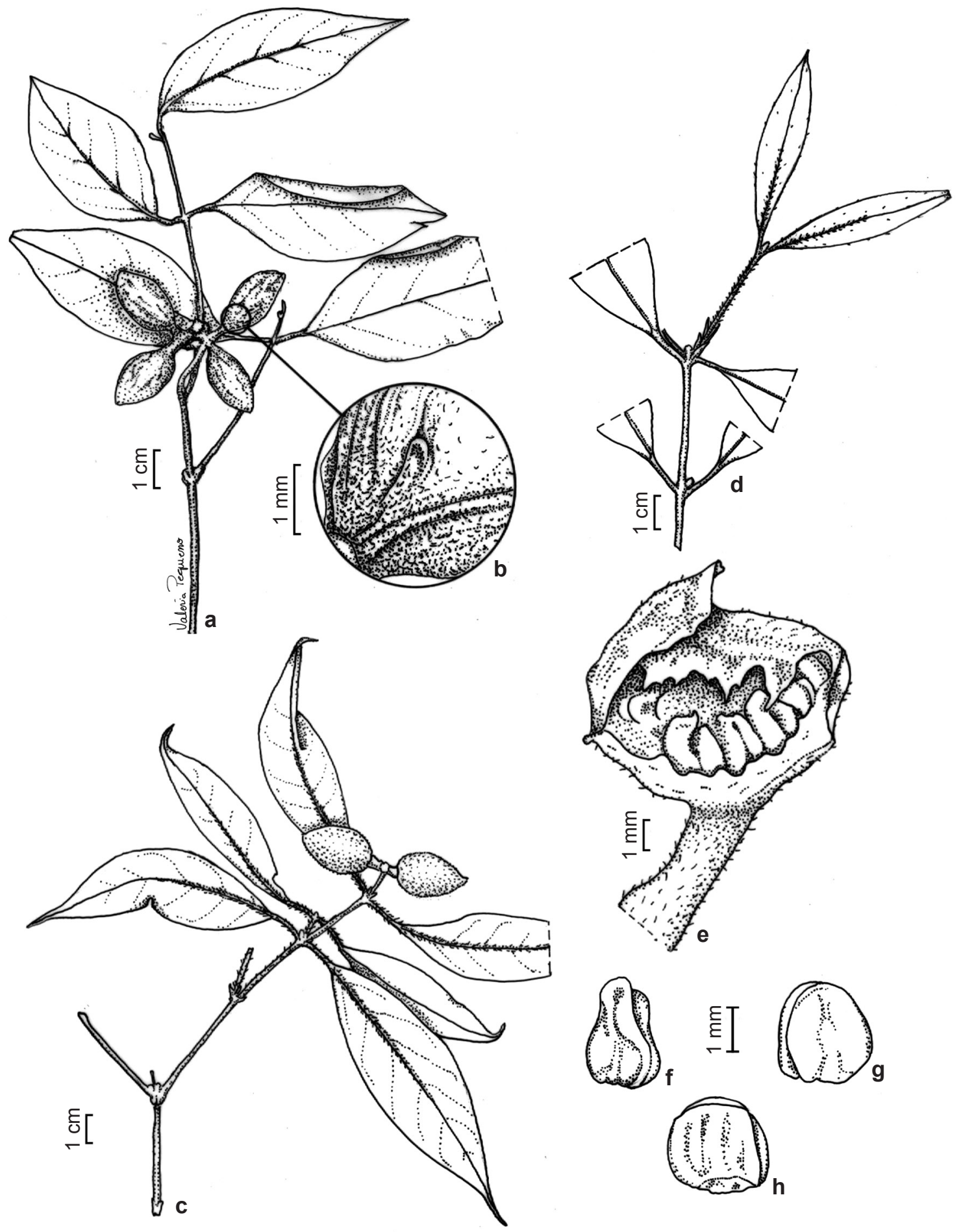

Figura 3 - a,b. Mollinedia argyrogyna - a. ramo com frutos; b. detalhe do indumento do fruto. c-h. Mollinedia dolichotricha - c. ramo com drupéolas; d. ramo jovem com catáfilos na base; e. flor estaminada em corte longitudinal; f-h. formato de estames. (b. Kollmann 2595; c. Vervloet 1953; d. Kollmann 1510). Ilustrações: Valéria Pequeno. Figure 3 - a,b. Mollinedia argyrogyna - a. branch with fruits, detail of fruit indument. c-h. Mollinedia dolichotricha - c. branch with fruits; d. young branch with cataphylls in the base; e. staminate flower in longitudinal section; f-h. stamens shape. (b. Kollmann 2595; c. Vervloet 1953; d. Kollmann 1510). Illustrations: Valéria Pequeno. 
hialinos, longos, patentes, ca. 1,8-2 mm. Folhas oblongas a elípticas, base cuneada a aguda, ápice longo atenuado ou acuminado, margem inteira, $7-12 \times 2,2-4 \mathrm{~cm}$, coriáceas, quando frescas verde-escuras na face adaxial e verde-claras na abaxial, quando secas marrons na face adaxial e castanhas na abaxial, esparso-pilosas na face adaxial e pilosas na face abaxial, principalmente ao longo das nervuras primária e secundárias, tricomas longos e patentes, nervuras secundárias 4-5 pares, imersas na face adaxial e proeminentes na face abaxial; pecíolo plano na face adaxial, $0,4-1 \mathrm{~cm}$, piloso. Flores estaminadas amarelas, sub-coriáceas, em fascículos de 2-3 cimas trifloras terminais, esparso pubescentes, pedúnculo ca. $0,5 \mathrm{~cm}$, brácteas triangular-alongados, ápice agudo, densamente coberta por tricomas longos e claros; pedicelo $0,25-3 \mathrm{~cm}$, bractéolas 4-2 $\mathrm{mm}$, triangular-alongadas, ápice agudo, com tricomas na margem e no dorso, principalmente no centro e ápice, receptáculo campanulado, 0,8-0,9 cm diâm., tépalas desiguais, externas mais curtas, ápice obtuso ou arredondado, internas mais longas, desiguais, uma com ápice obtuso e outra ápice arredondado, apêndice curto, fimbriado; estames sésseis 18-24, congestamente distribuídos no receptáculo, anteras deiscentes por fenda longitudinal contínua, as internas triangulares, $1,2-1,9 \times 1-2 \mathrm{~mm}$ as mais externas triangulares a ovadas, $2-2,5 \times 1,2-1,9$ $\mathrm{mm}$. Flores pistiladas desconhecidas. Drupéolas elípticas, 1,85-2,3 × 1,3 cm, ápice agudo, estilete persistente, não estipitadas, vilosas quando imaturas, glabrescentes quando maduras, quando secas castanhas, pedúnculo e pedicelo juntos 1-2 $\mathrm{cm}$, drupéolas maduras 2-9 por fruto, receptáculo frutífero $0,7-1,4 \mathrm{~cm}$ diâm.

Material selecionado: Santa Teresa, Estação Biológica de Santa Lúcia, 18.V.1993, fr., Thomaz 1273 (MBML, RB); 22.VI.1993, fl. mas, Thomaz 1659 (MBML, RB). Material adicional examinado: BRASIL. MINAS GERAIS: Santa Maria do Salto, Reserva do Alto Cariri, Fazenda Duas Barras, trilha da divisa Bahia-Minas Gerais, Floresta Ombrófila Densa Montana, 9.II.2006, fr., Amorim 5673 (RB, CEPEC).

Ocorre na Mata Atlântica, nos estados do Espírito Santo, Bahia e Minas Gerais. No Espírito Santo ocorrem em Santa Teresa, Itarana e Santa Maria de Jetibá (Hencker et al. 2012; Lírio et al. 2015). Ocorre em duas UCS: na Estação Biológica de Santa Lúcia e Reserva Biológica Augusto Ruschi.

Mollinedia dolichotricha distingue-se das demais espécies pelos tricomas longos, ca. $1,8-2 \mathrm{~mm}$, hialinos e patentes, dispostos predominantemente na nervura central das folhas e pelas brácteas e bractéolas cartáceas, agudas, patentes e com ápice provido de tricomas. Tem semelhança morfológica com $M$. argyrogyna, no formato das folhas, flores e frutos, entretanto distingue-se pelo indumento das folhas, consistência e indumento das brácteas e bractéolas (M. argyrogyna apresenta folhas, quando secas, amareladas na face adaxial e castanhas na face abaxial, glabrescentes e pontuadas na face adaxial, tomentosas na face abaxial; brácteas ovadas, ápice agudo, cerca de $4 \mathrm{~mm}$, bractéolas ovadas, ápice agudo, $2 \mathrm{~mm}$ ). Coletada com flores em junho, julho e agosto e frutos em janeiro, março, maio e dezembro.

3.3. Mollinedia engleriana Perkins, Bot. Jahrb. Syst. 27: 660, 1900. Tipo: BRASIL. RIO DE JANEIRO: Nova Friburgo, Alto Macaé, 20.VIII.1888, fl. mas, Glaziou 17766 (K! P! C, F, GH). $\quad$ Figs. 2c-e; 4a-g; 18b

Árvores até $14 \mathrm{~m}$ alt., dióicas, ramos cilíndricos, estriados, enegrecidos, glabros. Folhas elípticas, ápice acuminado, base aguda, obtusa ou arredondada, margem inteira ou 2-3 pares de dentes pouco a muito pronunciados no terço superior, 11-18 × 4,5-9,5 cm, frescas verde-escuras na face adaxial e verde-claras na face abaxial, crassas, quando secas enegrecidas em ambas as faces, cartáceas a rígido-cartáceas, pontuação não aparente, glabras; nervuras secundárias 6-10 pares, pouco aparentes na face adaxial, proeminentes na face abaxial, pecíolo canaliculado, 0,8-1,6 $\mathrm{cm}$. Flores estaminadas amarelas, em fascículos ou tirsos de até seis cimas trifloras, axilares ou terminais, glabras, exceto nas brácteas, raque $0-1,7 \mathrm{~cm}$, pedúnculo $0,6-1,6 \mathrm{~cm}$, brácteas ovadas, ápice agudo, alvo-pubescentes, 1,2-4,7 mm, pedicelo 1,6-2,2 cm, bractéolas ovadas, ápice acuminado ca. $1,6 \mathrm{~mm}$, receptáculo campanulado, $0,7-0,8 \mathrm{~cm}$ compr., ca. $0,6 \mathrm{~cm}$ diâm., tépalas $1 / 2$ do comprimento da flor, oblongas, ápice arredondado, externas com margens irregulares, internas inflexas, apêndices curtos, desiguais, uma com margem irregular, outra com margem fimbriada; estames 15-20, hipocrepiformes, filetes muito curtos, anteras deiscentes por fenda longitudinal contínua. Flores pistiladas amarelas, solitárias ou em fascículos de até quatro flores, glabras, exceto nas brácteas, raque $0,1-0,9 \mathrm{~cm}$, pedúnculo 0,1-1 cm, brácteas ovadas, ápice agudo, alvopubescentes $1,1-0,6 \mathrm{~mm}$, pedicelo $2,1-3,3 \mathrm{~cm}$, bractéolas ovadas, ápice acuminado, ca. 1,1 mm, 

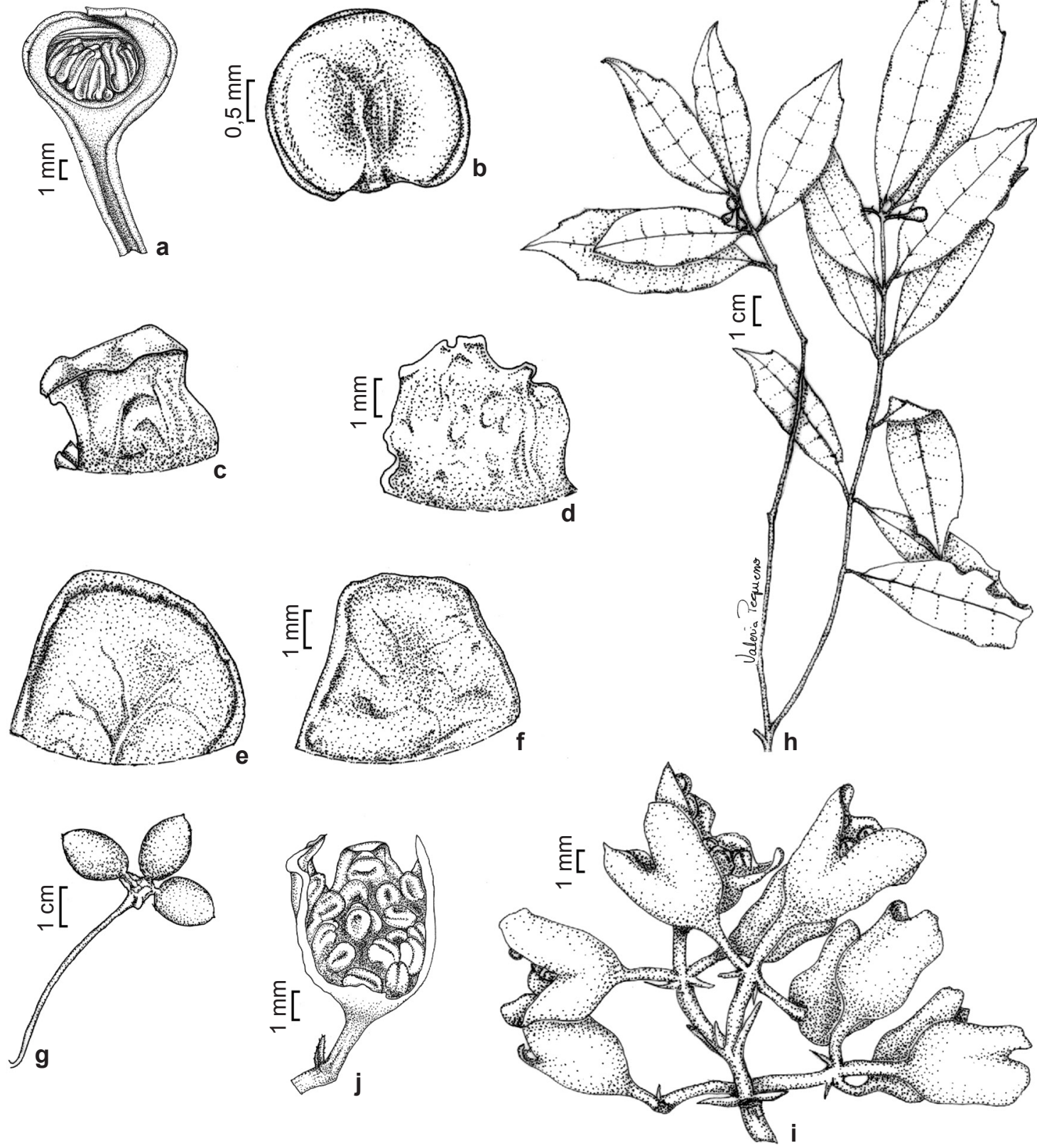

Figura 4 - a-g. Mollinedia engleriana - a. flor estaminada em corte longitudinal; b. estame; c-f. tépalas de flor estaminada; g. drupéolas. h-j. Mollinedia glabra - h. ramo com flores estaminadas em antese; i. inflorescência estaminada; j. flor estaminada em corte longitudinal exibindo os estames. (c-f. Lírio 47; g. Rossini 347; j. Demuner 2573). Ilustrações: Valéria Pequeno.

Figure 4 - a-g. Mollinedia engleriana - a. staminate flower in longitudinal section; b. stamen; c-f. tepals of staminate flower; g. fruits. $\mathrm{h}-\mathrm{j}$. Mollinedia glabra $-\mathrm{h}$. branch with staminate flowers in anthesis; i. staminate inflorescence; j. staminate flower in longitudinal section showing the stamens. (c-f. Lírio 47; g. Rossini 347; j. Demuner 2573). Illustrations: Valéria Pequeno. 
receptáculo cupuliforme, internamente ferrugíneoadpresso-viloso, 0,6 cm compr., 0,5-0,6 cm diam., tépalas ovadas, quase iguais entre si; carpelos 18-23, 3 mm compr., ovário ovado, até $1 / 3$ do comprimento do carpelo. Drupéolas orbiculares a elípticas, $0,9 \times 1,3 \mathrm{~cm}$, ápice arredondado, estilete persistente, estipitadas, quando secas negras, ásperas, pubérulas, pedúnculo e pedicelo juntos 2,5-3,6 cm, receptáculo frutífero 0,6-1 cm diâm. Material selecionado: Cariacica, Reserva Biológica Duas Bocas. Alegre, trilha do Pau Oco, 22.VII.2008, fl. mas, Fraga 2187 (MBML, RB). Santa Teresa, Estação Biológica Santa Lúcia, Trilha indaiaçu, 1.IX.2011, fl. mas, Lírio 47 (MBML, RB).

Endêmica da Mata Atlântica, nos estados do Espírito Santo, Rio de Janeiro e São Paulo (BFG 2015). No Espírito Santo ocorre em Cariacica e Santa Teresa, em floresta ombrófila densa. Tem ocorrência registrada em cinco UCs: a Reserva Biológica Duas Bocas, em Cariacica, e na Reserva Biológica Augusto Ruschi, Estação Biológica Santa Lúcia, Estação Biológica da Caixa D’água e Parque Natural Municipal de São Lourenço, no município de Santa Teresa.

Mollinedia engleriana difere das demais espécies pela coloração negra que adquirem as folhas, flores e ramos depois de secas ou em álcool, a ausência de pilosidade nos ramos e folhas combinada com as brácteas adpressopubescentes. Flores conservadas em álcool 70\% liberam substância negra que tinge completamente o líquido. Os espécimes coletados em Santa Teresa se diferenciam dos espécimes da localidade tipo pelas folhas mais largas e brácteas adpressopubescentes. Entretanto, a coloração que adquirem após desidratados, a consistência das folhas, o número de estames corroboram para sua inclusão nesta espécie. O receptáculo das flores estaminadas é caracterizado como plano na descrição original (Perkins 1900), referido como quase plano por Peixoto (1979), e nos espécimes do Espírito Santo são largamente campanulados. Coletada com flores em janeiro, abril, junho, julho, agosto, setembro e novembro e com frutos em abril, setembro e novembro.

3.4. Mollinedia gilgiana Perkins, Bot. Jahrb. Syst. 27(5): 656, 1900. Tipo: BRASIL. RIO DE JANEIRO: Nova Friburgo, Alto Macaé, 19.II.1888, fl. mas, Glaziou 17218 (BR! K!).

Figs. 5a-g; 18b

Árvores até $15 \mathrm{~m}$ alt., dióicas, ramos cilíndricos a subcilíndricos, ramos jovens ferrugíneo-tomentosos depois glabrescentes.
Folhas elípticas ou oblongas, ápice agudo, base cuneada ou arredondada, margem inteira ou 6-8 dentes pouco pronunciados, irregulares no terço superior, 11,4-35 × 4-14,5 cm, coriáceas, sem pontuações aparentes, frescas verde-escuras na face adaxial e mais claras na face abaxial, quando secas, marrons, geralmente cobertas de líquens na face adaxial, glabras ou glabrescentes na face adaxial, pubérulas na face abaxial, nervuras secundárias 6-8 pares, pouco aparentes de na face adaxial, proeminentes na face abaxial, pecíolo canaliculado, 1,2-1,4 cm. Flores estaminadas amarelas, em fascículos ou tirsos de 5-7 cimas trifloras, axilares ou terminais, ferrugíneo-tomentosas, raque 0-1,6 $\mathrm{cm}$, pedúnculo $0-1,9 \mathrm{~cm}$, brácteas ovadas, ápice agudo, ca. $3 \mathrm{~mm}$, pedicelo 0,2-1 cm, bractéolas ovadas, ápice agudo ca. $4 \mathrm{~mm}$; receptáculo plano, 0,3-0,8 cm compr., 0,3-0,4 cm diâm., tépalas 2/1 a 3/1 do comprimento da flor, ovadas, ápice arredondado, externas com margem inteira, internas desiguais, uma com margem inteira e outra com margem denticulada, estames 16-22, hipocrepiformes, filetes curtos, anteras deiscentes por fenda longitudinal. Flores pistiladas amarelas, solitárias ou fascículos de três a oito flores, raque 0-1,6 cm, pedúnculo 0-1,9 cm, brácteas elípticas, ápice agudo, ca. 0,5 mm, pedicelo 0,3-1,3 cm, bractéolas ovadas, ápice arredondado, 3-4,5 mm; receptáculo cupuliforme, internamente griseovelutino; 0,4-0,5 cm compr., 0,4-0,5 cm diam., tépalas $1 / 5$ do compr. da flor, ovadas, externas com ápice agudo, internas desiguais, uma com ápice agudo e outra com ápice retuso; carpelos sésseis 30-32, 1,4 mm compr., ovário oblongo, estilete com até $1 / 3$ do compr. do carpelo. Drupéolas eliptícas ou orbiculadas, 1,5-2,7 × 0,9-1,4 cm, ápice agudo, estilete persistente, não estipitadas, avermelhadas quando maduras, quando secas marrons, rugosas, alvo-pubescentes, pedúnculo e pedicelo juntos 2,3-5,2 cm, receptáculo frutífero com 0,6-1,2 cm diâm.

Material selecionado: Santa Maria de Jetibá, Rio Nove, terreno L.Kollmann, 24.II.2000, fr., Demuner 786 (MBML, RB). Santa Teresa, Estação Biológica de Santa Lúcia, beira do riacho, ao lado da trilha bonita, Trilha principal, 18.X.2011, fl. mas, Lírio 48 (MBML, RB).

Material adicional examinado: BRASIL. RIO DE JANEIRO: Itatiaia, Parque Nacional de Itatiaia, Trilha do Hotel Simon para Três Picos, 23.XI.1994, fl. fem, Braga 1631 (RB).

Endêmica da Mata Atlântica nos estados do Espírito Santo, Rio de Janeiro e São Paulo (BFG 2015). No Espírito Santo ocorre em Santa Matia do Jetibá e Santa Teresa, municípios fronteiriços entre 

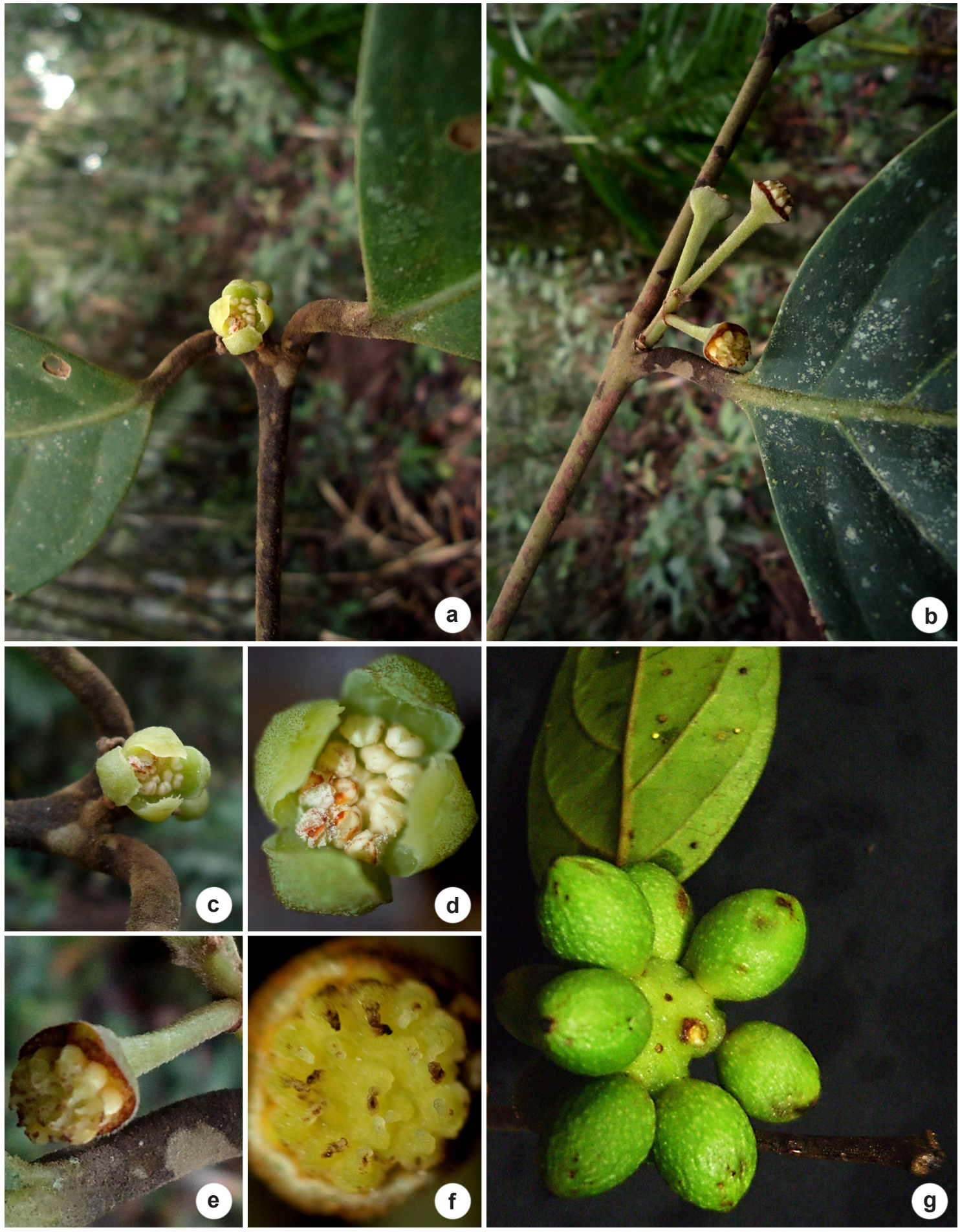

Figura 5 - a-g. Mollinedia gilgiana - a. ramo com flores estaminadas; b. ramo com flores pistiladas após queda da caliptra; c. Flor estaminada; d. detalhe da flor estaminada, estames da porção inferior em deiscência; e. flor pistilada após queda da caliptra; f. detalhe dos carpelos; g. Ramo com drupéolas. (a,c,d. Lírio 48; b,f. Lírio 40; g. Lírio 186). Fotos: E.J. Lírio.

Figure 5 - a-g. Mollinedia gilgiana - a. branch with staminate flowers; b. branch with pistillate flowers after calyptra fall; c. staminate flower; d. staminate flower detail, inferior stamens in dehiscence; e. pistillate flowers after calyptra fall; f. carpels detail; g. branch with fruits. (a,c,d. Lírio 48; b,f. Lírio 40; g. Lírio 186). Photos: E. J. Lírio. 
sí. Tem ocorrência registrada em três UCs: Reserva Biológica Augusto Ruschi (Nova Lombardia), Estação Biológica Santa Lúcia, e Parque Natural Municipal de São Lourenço, todas no município de Santa Teresa.

Difere das demais espécies do Espírito Santo pela pilosidade ferrugíneo-tomentosa nas inflorescências, associada ao receptáculo plano e tépalas ovadas, com ápice arredondado, assemelhase a $M$. glaziovii, pela cosistência e formato das folhas e flores, mas diferencia-se desta pela pilosidade pubérula na face abaxial das folhas e os estames com deiscência longitudinal contínua (vs. face abaxial das folhas vilosas, estames deiscentes por fendas laterais). As folhas e ramos são frequentemente cobertas por líquenes e fungos. Esta mesma observação foi feita nos espécimes da localidade típica da espécie, Macaé de Cima em Nova Friburgo, Rio de Janeiro. Coletada com flores em agosto, outubro, dezembro e janeiro e frutos em fevereiro, março, maio, julho e agosto.

3.5. Mollinedia glabra (Spreng.) Perkins, Bot. Jahrb. Syst. 27: 657, 1900. Tipo: BRASIL. RIO DE JANEIRO: s.l., s.d., fl. mas., Sellow 'L 485-B 580" (BM! K!). $\quad$ Figs. 4h-j; 11a; 18c Citriosma glabra Spreng., Syst. Veg. 2: 545, 1825.

Arbustos a arvoretas até $4 \mathrm{~m}$ alt., dióicos, ramos cilíndricos, lisos, glabros. Folhas elípticas a estreito-elípticas, ápice agudo ou acuminado, base aguda ou cuneada, margem inteira ou 1-3 pares de dentes irregulares no terço superior, 5,1-16,3 × 1,5$7,2 \mathrm{~cm}$, papiráceas a cartáceas (coriáceas somente quando sobre afloramentos rochosos), castanhas ou oliváceas, nítidas, pelúcido-pontuadas, glabras, nervuras secundárias 9-14 pares, pouco aparentes na face adaxial, proeminulas na abaxial; pecíolo canaliculado, 0,3-1,5 cm. Flores estaminadas amarelas, em fascículos de até 4 tríades, terminais, glabras, raque $0,1 \mathrm{~cm}$, pedúnculo $0,4-0,8 \mathrm{~cm}$, brácteas lanceoladas, ápice agudo, 0,6-0,9 mm, pedicelo $0,15-0,25 \mathrm{~cm}$, bractéolas lanceoladas, ápice agudo, 1,9-2 $\mathrm{mm}$; receptáculo urceolado, $0,4-0,6 \mathrm{~cm}$ compr., ca. $0,4 \mathrm{~cm}$ diâm., tépalas $1 / 3$ do compr. da flor, ovadas, ápice agudo, internas geralmente com margem denticulada; estames 30-40, hipocrepiformes, filetes dos estames basais curtos, apicais alongados, anteras deiscentes por fenda longitudinal contínua. Flores pistiladas amarelas, solitárias ou em fascículos 2-floros, terminais, glabras, raque $0-0,2 \mathrm{~cm}$, pedúnculo $0,2-0,7 \mathrm{~cm}$, brácteas lanceoladas, ápice agudo, ca. $1,8 \mathrm{~mm}$, pedicelo $0,7-1,1 \mathrm{~cm}$, bractéolas ovadas, ápice agudo, ca. $1 \mathrm{~mm}$; receptáculo cupuliforme, internamente glabro, ca. 0,35 cm compr., 0,39 $\mathrm{cm}$ diâm., tépalas $1 / 5$ do compr. da flor, ovadas, ápice agudo, externas maiores; carpelos 14-18, $0,18-0,2 \mathrm{~cm}$ compr., ovário oblongo, estilete $1 / 5$ do compr. do carpelo. Drupéolas elípticas, 1-1,6 $\times$ $0,5-0,8 \mathrm{~cm}$, ápice agudo, estilete persistente, não estipitadas, maduras vináceas, secas marron-claras, glabras, pedúnculo e pedicelo juntos $0,5-1,8 \mathrm{~cm}$, receptáculo frutífero $0,2-0,8 \mathrm{~cm}$ diâm.

Material selecionado: Aracruz, Base do Picuã, entrada por Aracruz, 6.VI.2013, fr., Lírio 411 (RB, MBML). Castelo, Parque Estadual de Forno Grande, 30.X.2004, fl. fem, Kollmann 7149 (RB, MBML). São Roque do Canaã, entrada da Pedra Três Carneiros, 2.VII.2013, fl. mas, Lírio 452 (RB, MBML).

Ocorre na Mata Atlântica, nos estados da Bahia, Espírito Santo, Rio de Janeiro e São Paulo (BFG 2015). No Espírito Santo ocorre em oito municípios: Conceição da Barra, Águia Branca, Aracruz, Colatina, São Roque de Canaã, Santa Leopoldina, Santa Teresa, Guarapari e Castelo. Foi coletada em floresta ombrófila densa e afloramentos rochosos, em terrenos do Précambriano, em floresta de tabuleiros na transição entre mussununga e campos nativos, nos tabuleiros terciários, e em matas de restinga em terrenos quaternários. Ocorre em três UCs: Parque Estadual de Forno Grande, no município de Castelo, Parque Estadual de Itaúnas, em Conceição da Barra, na Reserva Natural Vale, em Linhares e Parque Estadual Paulo Cesar Vinha, em Guarapari.

Mollinedia glabra se diferencia das demais espécies pelas folhas castanhas ou oliváceas, nítidas, glabras, inflorescências terminais, glabras ou pubescentes, flores com receptáculo urceolado, estames basais com filetes curtos e apicais com filetes mais longos. O espécime oriundo de afloramento rochoso apresenta folhas menores e de consistência mais rígida do que os demais espécimes; entretanto, todos os demais caracteres florais são concordantes com a espécie. Coletada com flores de junho a setembro e frutos de fevereiro a abril, junho a agosto, outubro e novembro.

3.6. Mollinedia glaziovii Perkins, Bot. Jahrb. 27: 657, 1900. Tipo: BRASIL. RIO DE JANEIRO: Nova Friburgo, Alto Macaé, II. s.d., fl., Glaziou 17119 (C, BR! K! P! GH). Figs. 6a-h; 18c

Árvores 8-10 $\mathrm{m}$, dióicas, ramos subcilíndricos, ramos jovens ferrugíneo-vilosos, depois glabrescentes. Folhas elípticas, ápice agudo, base cuneada, margem inteira, raro 1-3 pares de dentes irregulares, pouco pronunciados, 
9,1-23,5 × 3,1-7,6 cm, coriáceas, quando secas marron-escuras na face adaxial e castanhas na abaxial, vilosas na face abaxial, principalmente ao longo das nervuras, glabrescentes na adaxial, exceto nas nervuras, nervuras secundárias 6-9 pares, proeminentes na face abaxial, pecíolo canaliculado ou com canalículo apenas no ápice, 0,8-1,9 cm. Flores estaminadas esverdeadas, em tirsos de até 7 cimas trifloras, axilares ou terminais, ferrugíneo-vilosas, raque $0,5-0,8 \mathrm{~cm}$, pedúnculo $0,5-0,8 \mathrm{~cm}$, brácteas oblongas, ápice agudo, 3-6 $\mathrm{mm}$, pedicelo $0,2-0,5 \mathrm{~cm}$, bractéolas oblongas, ápice agudo 5-5,5 $\mathrm{mm}$; receptáculo plano, 0,45 cm compr. $0,48 \mathrm{~cm}$ diâm., tépalas $2 / 3$ do compr. da flor, ovadas, ápice arredondado, externas com margem inteira, internas com margem denteada; estames 27, anteras com lóculos não confluentes, filetes nulos. Flores pistiladas esverdeadas, isoladas ou em tirsos de até 7 flores, axilares ou terminais, ferrugíneo-vilosas, raque 1,3-1,6 cm, pedúnculo 0,7-1 cm, brácteas caducas, pedicelo 0,9-1,3 $\mathrm{cm}$, bractéolas ovadas, ápice arredondado, ca. 4

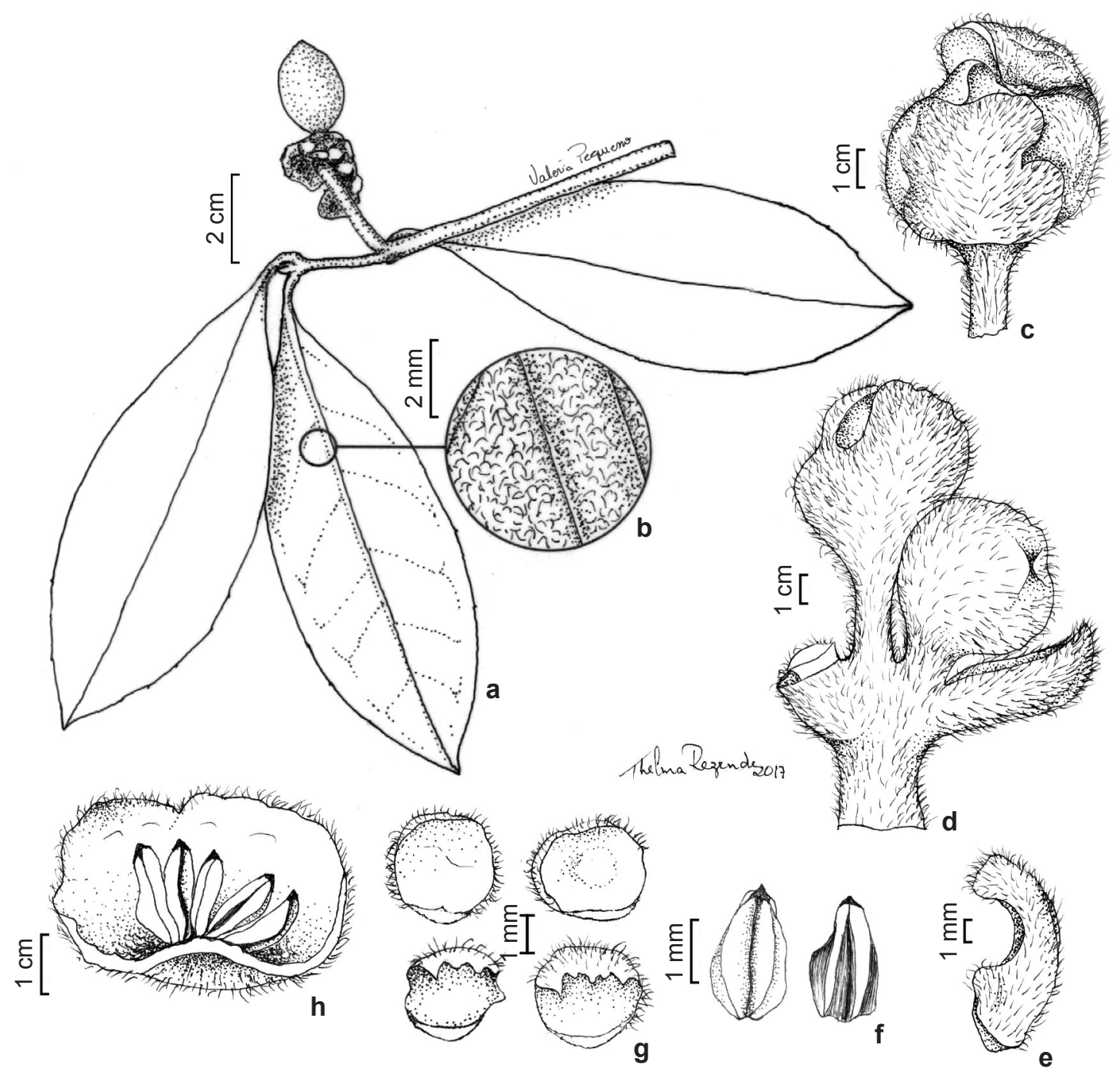

Figura 6 - a-h. Mollinedia glaziovii - a. ramo com fruto; b. detalhe da face abaxial da folha; c. flor estaminada; d. inflorescência estaminada; e. brácteola; f. estames em vista frontal e lateral; g. tépalas da flor estaminada; h. flor em corte longitudinal exibindo estames. Ilustrações: a,b. Valéria Pequeno; c-h. Thelma Rezende.

Figure 6-a-h. Mollinedia glaziovii - a. branch with fruits; b. detail of the abaxial leaf face; c. staminate flower; d. staminate inflorescence; e. bractlet; f. stamens in front and side view, g. staminate flower tepals; h. flower in longitudinal section showing stamens. Illustrations: a,b. Valéria Pequeno; c-h. Thelma Rezende. 
$\mathrm{mm}$; receptáculo plano, internamente ferrugíneovelutino, 0,8-1,1 cm diâm.; carpelos 33-34, ca. 0,3 cm compr., ovário ovado, estilete verrucoso com 1/3 do compr. do carpelo. Drupéolas elípticas, 1,9$2 \times 1,4-1,5 \mathrm{~cm}$, ápice agudo, estilete persistente, não estipitadas, quando secas marrons, ásperas, velutinas, pedúnculo e pedicelo juntos 1,9-2,2 cm, receptáculo frutífero $1,1-1,8 \mathrm{~cm}$ diâm.

Material selecionado: Santa Teresa, Reserva Biológica Augusto Ruschi, Nova Lombardia, 5.XI.2002, fr., Vervloet 1373 (MBML). São Lourenço, Parque Natural Municipal São Lourenço, próximo à área 1, 27.XII.2003, fl. mas, Cruz 113 (MBML, RB).

Material adicional examinado: BRASIL. RIO DE JANEIRO: Nova Friburgo, Reserva Ecológica Municipal de Macaé de Cima, nascente do Rio das Flores, 26.XI.1986, fl. mas, Martinelli 11902 (RB, NY); Picada p/ Pedra Bicuda, 19.IV.1989, fl. fem, Lima 3534 (RB, CEPEC, NY).

Endêmica da Mata Atlântica, nos estados do Espírito Santo e Rio de Janeiro (BFG 2015), em Floresta Ombrófila Densa montana. No Espírito Santo é conhecida por coletas realizadas no município de Santa Teresa, onde está representada em duas UCs: Reserva Biológica Augusto Ruschi (Nova Lombardia) e Parque Natural Municipal São Lourenço, também foi avistada em estado estéril no município de Fundão, no Parque Natural Municipal de Goiapaba-Açú.

Assemelha-se morfologicamente a $M$. gilgiana pelo formato das folhas e do receptáculo das flores estaminadas, no entanto, difere pelas folhas e ramos vilosos e deiscência das anteras por fendas laterais não contínuas ( $v s$. folhas e ramos glabros ou glabrescentes e anteras com deiscência por fenda longitudinal contínua em $M$. gilgiana). Coletada com flores em dezembro e frutos em novembro.

3.7. Mollinedia lamprophylla Perkins, Bot. Jahrb. 27: 656, 1900. Tipo: BRASIL. RIO DE JANEIRO: Rio de Janeiro, Laranjeiras, 26.VIII.1891, fl. fem, Glaziou 18484 (P! K! F, C, GH). Figs. 7a,b; 18c

Arbustos ou árvores 3-10 m, dióicos, ramos cilíndricos, ramos jovens flavescente-tomentosos, depois glabrescentes. Folhas elípticas ou obovadas, ápice agudo, base obtusa, raro arredondada, margem com 7-30 pares de dentes pouco pronunciados desde o terço inferior, $14,7-30,5 \times 5,1-12,7 \mathrm{~cm}$, coriáceas, buladas a levemente buladas, amareloesverdeadas quando secas, glabra na face adaxial, exceto na nervura principal e na margem, que apresenta uma linha contínua de pelos, tomentosas na face abaxial, nervuras secundárias 8-14 pares, proeminentes na face abaxial, afundadas na face adaxial; pecíolo canaliculado, tomentoso, 1,2-2,4 $\mathrm{cm}$. Flores estaminadas amareladas, em tirsos de 3-6 cimas trifloras, terminais, áureo-tomentosas, raque $1,2-1,5 \mathrm{~cm}$, pedúnculo $0,5-0,6 \mathrm{~cm}$, brácteas oblongas, ápice agudo, ca. $8 \mathrm{~mm}$, pedicelo $0,3-0,5$ $\mathrm{cm}$, bractéolas ovadas, ápice agudo, 3-6 mm; receptáculo quase plano, $0,5-0,6 \mathrm{~cm}$ compr., 0,6-0,8 cm diâm., tépalas $1 / 2$ do compr. da flor, ovados, externas desiguais, uma com ápice arredondado, outra apêndice curto denteado, internas desiguais, uma com apêndice curto, margem irregular, outra apêndice longo, margem denteada; estames (40-)80-82, congestos, filetes nulos, anteras deiscentes por fenda longitudinal contínua, interiores hipocrepiformes, mais externas ovadas. Flores pistiladas em tirsos terminais, áureo-tomentosas, pedúnculo $0,2-0,3 \mathrm{~cm}$, brácteas ovadas, ápice agudo, ca. $0,6 \mathrm{~cm}$, pedicelo ca. 0,7 $\mathrm{cm}$, bractéolas ca. $0,7 \mathrm{~cm}$, receptáculo plano, internamente áureo-velutino, ca. 0,9 cm diâm., tépalas desconhecidas, 18-19 carpelos. Drupéolas elípticas ou oblongas, 1,5-3 × 0,9-1,9 cm, ápice agudo, estilete persistente, não estipitadas, quando secas castanhas, ásperas, velutinas, pedicelo e pedúnculo frutíferos juntos $1,5-2,4 \mathrm{~cm}$, receptáculo $0,7-1,5 \mathrm{~cm}$ diâm.

Material selecionado: Linhares, Estrada Jureana Vermelha, próximo à casa do guarda (Barra Seca), 11.IV.2006, fr., Freire 151 (RB, CVRD, ESA). Santa Teresa, São Lourenço, terreno de Clerio Loss, 8.VII.1998, fr., Kollmann 183 (MBML, RB).

Material adicional selecionado: BRASIL. RIO DE JANEIRO: Rio de Janeiro, Laranjeiras, Corcovado, VII.1891, fl fem, Glaziou 18484 (K).

Endêmica da Mata Atlântica, nos estados do Espírito Santo e Rio de Janeiro (BFG 2015). No Espírito Santo ocorre em Águia Branca, Pinheiros, Linhares e Santa Teresa, tanto em Floresta Ombrófila densa como em floresta de tabuleiro.

Assemelha-se a $M$. marqueteana pelo indumento, formato e consistência das folhas e flores. No protólogo desta espécie elas são distintas principalmente pelos frutos alongados, amarelados e flavescente-tomentosos em M. lamprophylla e arredondados, nigrescentes e glabrescentes quando secos em M. marqueteana, que é descrita para as florestas de tabuleiros (Peixoto 1988). No entanto, em materiais examinados oriundos de uma das localidades de um parátipo (Linhares, ES) foram observados frutos alongados e flavescentetomentosos, como em M. lamprophylla, que é descrita para a Floresta Ombrófila densa (Laranjeiras, Corcovado, Rio de Janeiro). Um 


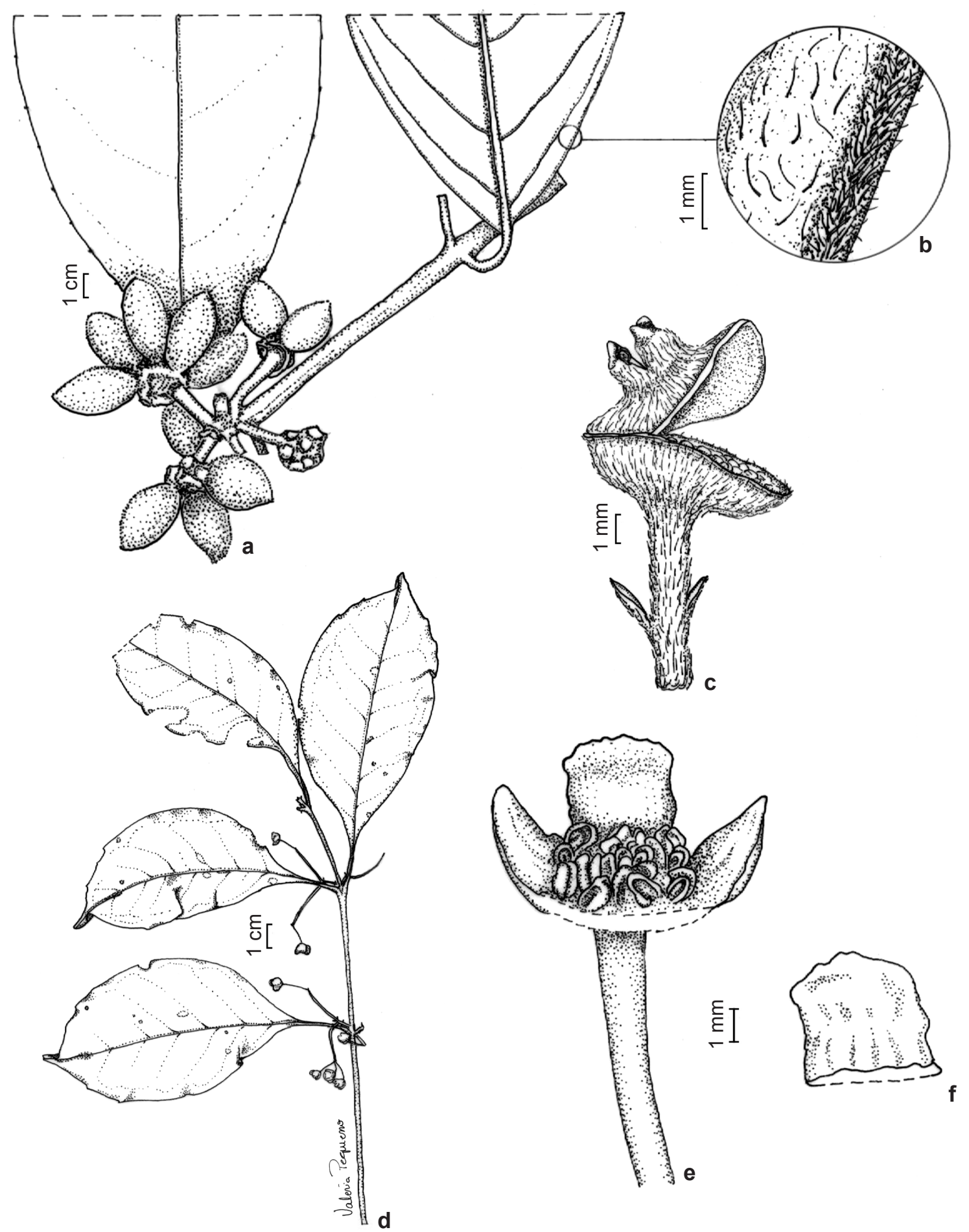

Figura 7 - a,b. Mollinedia lamprophylla - a. ramo com drupéolas; b. detalhe da margem da folha. c. Mollinedia longifolia - flor pistilada com caliptra em circuncisão. d-f. Mollinedia oligantha - d. ramo com flores estaminadas em antese; e. flor estaminada com incisão de uma tépala interna, f. tépala interna. (b. Freire 151). Ilustrações: Valéria Pequeno.

Figure 7 -a,b. Mollinedia lamprophylla - a. branch with fruits; b. leaf margin detail. c. Mollinedia longifolia - c. pistillate flower with caliptra in circumcision. d-f. Mollinedia oligantha $-\mathrm{d}$. branch with staminate flowers in anthesis; e. staminate flower with incision of an internal tepal; f. inner tepal. (b. Freire 151). Illustrations: Valéria Pequeno. 
espécime de Santa Teresa (Kollmann 183), portanto de Floresta Ombrófila Densa, apresenta frutos nigrescentes e glabrescentes (como aqueles de $M$. marqueteana). Desta forma, é necessário acompanhar a floração e frutificação, além de examinar materiais de outros estados dessas duas espécies, para melhor compreedê-las. Coletada com flores em julho e agosto e frutos em janeiro, abril, junho a setembro e dezembro.

3.8. Mollinedia longifolia Tul., Ann. Sci. Nat., Bot. ser. 4, 3: 41,1855. Tipo: BRASIL. RIO DE JANEIRO: Santa Cruz, 1814-1815, Sellow 488 (MEL, P! C, GH).

Figs. 7c; 8; 18d

Arbustos até $4 \mathrm{~m}$, dióicos, ramos subcilíndricos, jovens densamente ferrugíneotomentosos, depois glabrescentes a glabros. Folhas oblongas, ápice acuminado, raro agudo, base cuneada ou obtusa, margem com 5 a 10 pares de dentes na metade ou no $2 / 3$ superior, 12,9-21,4 $\times 3,2-7,5 \mathrm{~cm}$, cartáceas, verde-escuras na face adaxial e castanhas na face abaxial, quando secas amarronzadas na face adaxial e marrons na face abaxial, jovens ferrugíneo-tomentosas em ambas as faces, depois glabrescentes ou glabras na face adaxial, nervuras secundárias 6-10 pares, proeminentes na face abaxial; pecíolo canaliculado na porção distal, raro plano, 0,9-1,5 cm. Flores estaminadas amarelas, em fascículos ou tirsos de até 8 cimas trifloras, axilares ou terminais, ferrugíneo-tomentosas, raque $0-1,3 \mathrm{~cm}$, pedúnculo 0,3-0,8 cm, brácteas lanceoladas, ápice agudo, ca. $1,9 \mathrm{~mm}$, pedicelo $0,2-05 \mathrm{~cm}$, bractéolas ovadas, ápice agudo, ca. $1 \mathrm{~mm}$; receptáculo cupuliforme, 0,2-0,4 cm compr., 0,3-0,6 cm diâm., tépalas $1 / 3$ do compr. da flor, ovadas, externas com ápice agudo, internas arredondadas, desiguais, ápice com apêndice inflexos, uma com margem inteira, outra com margem fimbriada; estames 20-34, hipocrepiformes, deiscentes por fendas contínuas, os basais com filetes curtos, os apicais com filetes nulos. Flores pistiladas amarelas, solitárias ou em fascículos de até 2 flores, ferrugíneo-tomentosas, raque nula, pedúnculo $0-0,3 \mathrm{~cm}$, brácteas ovadas, ápice agudo, $2 \mathrm{~mm}$, pedicelo $0,1-0,5 \mathrm{~cm}$, bractéolas ovadas, ápice agudo, $1-1,5 \mathrm{~mm}$; receptáculo cupuliforme, internamente ferrugíneo-velutino, ca. 0,4 cm compr., 0,4-0,5 cm diâm., tépalas $1 / 6$ do compr. da flor, ovadas, externas com ápice agudo, internas com ápice arredondado; carpelos 19-46, 0,2-0,22 cm compr., ovário obovado, estilete verrucoso com 1/2 do compr. do carpelo. Drupéolas orbiculares ou elípticas, $1-1,8 \times 0,6-1 \mathrm{~cm}$, ápice agudo, estilete persistente, não estipitadas, vináceas quando maduras, quando secas castanhas, rígidas, ásperas, puberulentas, pedúnculo e pedicelo juntos 0,1-2,1 cm, receptáculo frutífero 0,4-1,2 cm diâm. Material selecionado: Castelo, Floresta Ombrófila Densa montana, 9.IV.2009, fr., Kollmann 11521 (MBML, RB). Santa Teresa, Estação Biológica de Santa Lúcia, 28.VI.2004, fl. mas, Kollmann 6911 (MBML, RB).

Endêmica da Mata Atlântica, nos estados do Espírito Santo e Rio de Janeiro (BFG 2015). No Espírito Santo ocorre nos municípios de Águia Branca, Marilândia, Santa Leopoldina, Santa Teresa, Castelo e Vargem Alta. Tem ocorrência registrada em três áreas protegidas no município de Santa Teresa: Estação Biológica de Santa Lúcia, Parque Natural Municipal São Lourenço e Mata do Banestes, em Floresta Ombrófila densa.

Mollinedia longifolia se assemelha a $M$. schottiana pelo indumento e coloração das folhas quando secas. Mas diferencia-se por apresentar folhas até três vezes mais compridas em relação à largura, flores com tépalas com 1/3 do compr. da flor e estames basais com filetes curtos e apicais mais longos ( $v s$. folhas com comprimentos nunca $3 x$ maior que a largura, tépalas com $1 / 2$ do compr. da flor e estames com filetes nulos). Coletada com flores em abril, junho a agosto e setembro e frutos de janeiro a maio, julho, agosto e dezembro.

3.9. Mollinedia marqueteana Peixoto Arq. Univ. Fed. Rur. Rio de Janeiro 11: 59, 1988. Tipo: BRASIL. BAHIA: Porto Seguro, Eunápolis, Itabela, 3.VII.1970, fl. mas, Santos 877 (CEPEC!, $\mathrm{RB}$ !).

Figs. 9; 18d

Árvores 5-15 m de altura, caule cilíndrico, amarronzado, ramos cilíndricos, quando jovens densamente ferrugíneo-tomentosos, adultos glabrescentes. Folhas elípticas, na face adaxial glabrescentes, exceto ao longo das nervuras e margens foliares, tomentosas na face abaxial, margem com linha contínua de tricomas, tricomas ásperos, 10-18 pares de dentes pouco pronunciados, $15-18 \mathrm{~cm} \times 6,5-9,5 \mathrm{~cm}$, coriáceas, buladas, nervuras secundárias 4-6 pares, imersas na face adaxial e proeminentes na face abaxial, pecíolo $1-1,2$ $\mathrm{cm}$, tomentoso. Flores estaminadas em cimeiras trifloras arranjadas em tirsos com 12-18 flores dispostas congestamente, terminais, ferrugíneas a flavescente tomentosas; raque ca. $1 \mathrm{~cm}$, pedúnculo 0,6-0,7 cm, bractéas ovadas, ápice agudo, ca. 0,4 $\mathrm{cm}$, pedicelo $0,4-0,5 \mathrm{~cm}$, bractéolas ovadas, ápice agudo, ca. 0,5 cm, receptáculo campanulado 0,50,6 cm compr., 0,9-1 cm diâm., tépalas $0,4-0,5 \mathrm{~cm}$ 

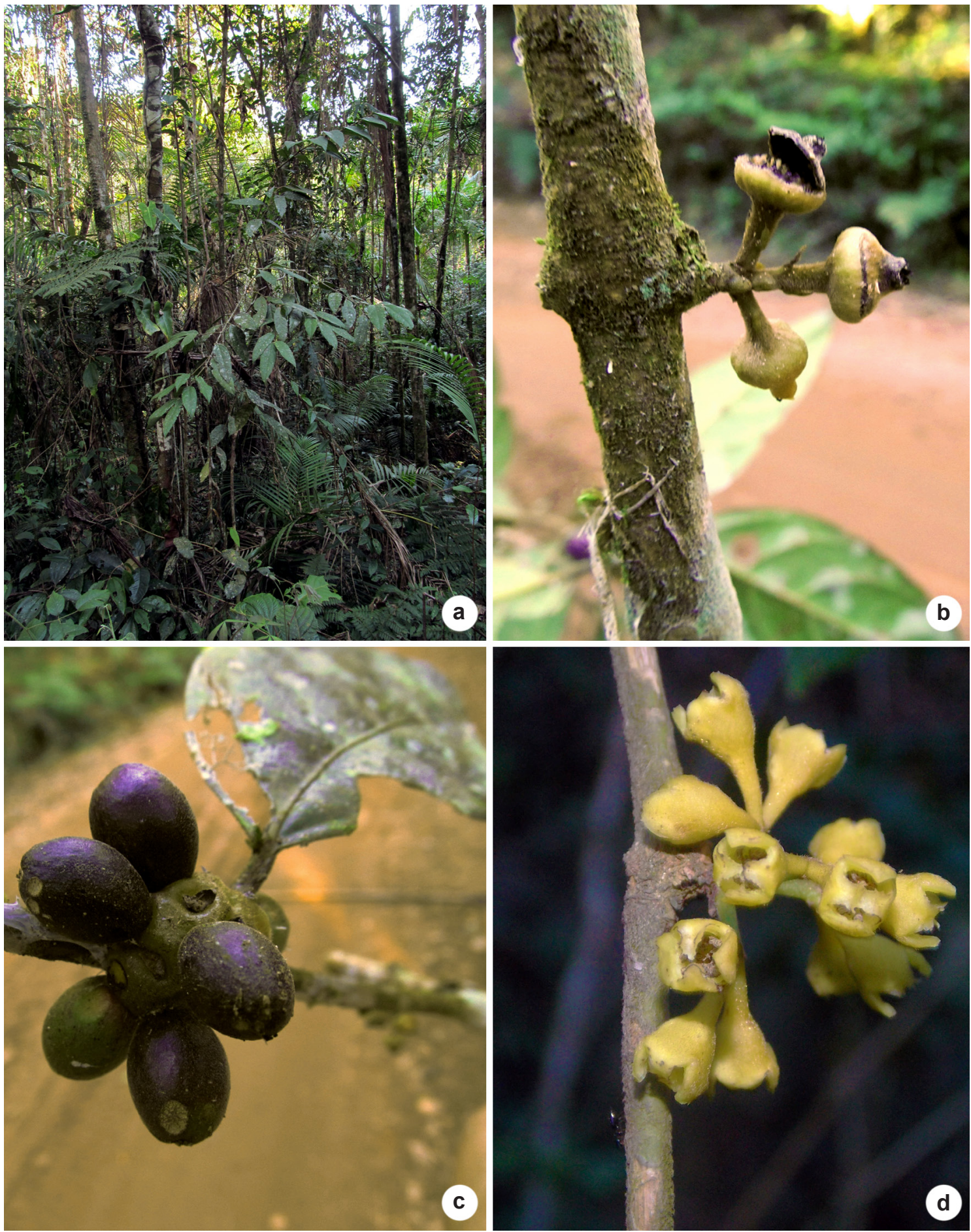

Figura 8 - a-d. Mollinedia longifolia - a. hábito; b. ramo com flores pistiladas; c. ramo com drupéolas; d. flor estaminada em antese. (c. Lírio 192; d. Lírio 1280). Fotos: a-c. V. Sarnaglia; d. E.J. Lírio.

Figure 8 - a-d. Mollinedia longifolia - a. habit; b. branch with pistillate flowers; $c$. branch with fruits; d. staminate flowers in anthesis. (c. Lírio 192; d. Lírio 1280). Photos: a-c. V. Sarnaglia; d. E.J. Lírio. 

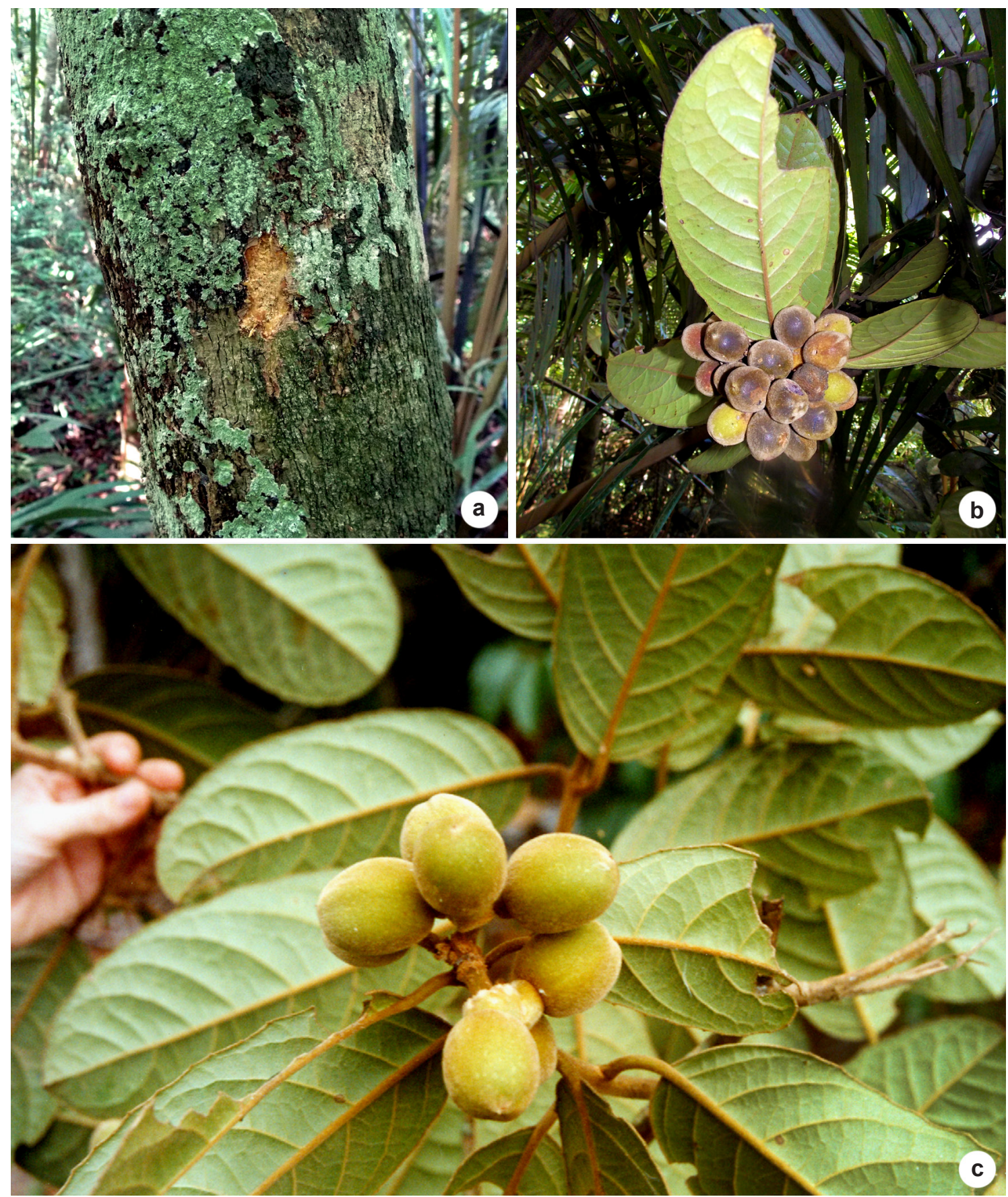

Figura 9 - a-c. Mollinedia marqueteana - a. tronco; b. frutos maduros; c. frutos imaturos coletados na Reserva Natural Vale. (b. Lírio 1116). Fotos: a,b. E.J. Lírio.

Figure 9 - a-c. Mollinedia marqueteana - a. stem; b. ripe fruits; c. immature fruits collected in Reserva Natural Vale. (b. Lírio 1116). Photos: a,b. E.J. Lírio. 
de compr., as internas com margem glabra; estames ca. 42, congestamente dispostos no receptáculo, anteras aplanadas, hipocrepiformes, deiscentes por fenda longitudinal contínua. Drupéolas elíptcas, ca. $1,6 \times 1,1$, nigrescentes, velutinas quando jovens, depois glabrescentes e com um anel de tricomas contornando o estilete persistente, pedúnculo e pedicelo frutíferos juntos 1,5-1,6 cm, receptáculo frutífero 1-1,3 cm diâm.

Material selecionado: Santa Teresa, São Lourenço, terreno de Clerio Loss, 8.VII.1998, fr., Kollmann 183 (MBML, RB). Linhares, Reserva Florestal da CVRD, 5.IX.1980, fl. mas, Peixoto 1435 (RBR) [Parátipo].

Material adicional selecionado: BRASIL. BAHIA: Itabela, Banápolis, 3.VII.1970, fl. mas, Santos 877 (RB) [Isótipo].

Endêmica da Mata Atlântica, nos estados da Bahia e Espírito Santo (BFG 2015). No Espírito Santo foi coletada em Linhares e Santa Teresa, em Floresta de Tabuleiro e Floresta Ombrófila Densa Montana. Tem ocorrencia registrada em uma UC: Reserva Natural Vale.

Mollinedia marqueteana assemelha-se a $M$. lamprohylla pelo indumento, formato e consistência das folhas e flores. No protólogo são distintas pelos frutos arredondados, nigrescentes e glabrescentes quando secos na primeira, e alongados, amarelados e flavescente-tomentosos em M. lamprophylla, e pelos tricomas mais ásperos das folhas da primeira. É necessário o acompanhamento da floração e frutificação destas duas espécies para melhor compreendê-las. Coletada com flores em agosto e setembro e frutos em julho.

3.10. Mollinedia oligantha Perkins, Bot. Jahrb. 27: 653, 1900. Tipo: BRASIL. RIO DE JANEIRO: Nova Friburgo, Alto Macaé, 19.II.1891, fl. mas, Glaziou 18487 (K! P! C, F, GH).

Figs. 7d-f; 11c; 18d

Arbustos até $3 \mathrm{~m}$, dióicos, ramos cilíndricos a subcilíndricos, longitudinalmente estriados, glabros. Folhas elípticas, ápice acuminado, base cuneada, margem inteira, raro com 2-4 dentes no terço superior, margem revoluta, 9-17,5 × 3,5-8,8 $\mathrm{cm}$, cartáceas, sem pontuações aparentes, oliváceas, glabras, nervuras secundárias 5-7 pares, aparentes na face adaxial, proeminentes na abaxial, pecíolo canaliculado, 0,63-1,53 cm. Flores estaminadas amarelas, pruinosas, em tirsos de até 4 cimas, axilares ou terminais, glabras, exceto nas brácteas, raque $0,3-0,4 \mathrm{~cm}$, pedúnculo $1,3-2,1 \mathrm{~cm}$, brácteas ovadas, ápice agudo, 1,9 mm, pedicelo 0,4-0,9 $\mathrm{cm}$, bractéolas ovadas, ápice agudo, 1,1-1,3 $\mathrm{mm}$, receptáculo plano, 0,39-0,44 cm compr., 0,53-0,83 cm diâm., tépalas $4 / 5$ do compr. da flor, ovadas, externas com ápice arredondado, internas desiguais, uma com ápice truncado outra denticulado; estames 16-20, filetes nulos, anteras deiscentes por fenda longitudinal contínua. Flores pistiladas não examinadas. Drupéolas elípticas, ca. 1,2 ×0,8 cm, ápice agudo, estilete persistente, não estipitadas, quando secas castanhas, rígidas, ásperas, pedúnculo e pedicelo juntos $0,9-1,1 \mathrm{~cm}$, receptáculo frutífero ca. $0,4 \mathrm{~cm}$ diâm.

Material selecionado: Ibitirama, Parque Nacional do Caparaó, 25.I.2013, fl. mas, Dias 815 (RB, VIES). Santa Teresa, Estação Biológica Santa Lúcia, 28.IX.2011, fl. mas, Lírio 45 (MBML, RB).

Material adicional selecionado: BRASIL. RIO DE JANEIRO: IV.1838, fr., Miers 3941 (RB).

Endêmica da Mata Atlântica, ocorre nos estados do Rio de Janeiro e Espírito Santo (BFG 2015). No Espírito Santo, foi registrada em Santa Teresa e Ibitirama. Ocorre na área protegida Estação Biológica de Santa Lúcia, em Santa Teresa.

Se diferencia das demais espécies do Espírito Santo pelas folhas glabras e oliváceas e receptáculo plano com cobertura pruinosa esbranquiçada que se desprende facilmente. Foram usualmente encontrados trips (Thysanoptera) em flores estaminadas da espécie. Os dois exemplares examinados são da Floresta Ombrófila Densa montana e alto-montana e foram coletados com flores em janeiro e setembro.

3.11. Mollinedia ovata Ruiz \& Pav., Syst. Veg. Fl. Peruv. et Chil. 1: 143, 1798. Tipo: PERU. HUÁNUCO: Chinchao, Ruiz \& Pavón 905 (MA, $\mathrm{B}$ destruído).

Figs. 12a-c; 19a

Arbustos 2,5-6 m, dióicos, ramos cilíndricos, estriados, pubérulos, depois glabrescentes ou glabros. Folhas ovadas ou elípticas, ápice acuminado, raro falcado, base aguda, raro obtusa, margem com 3-9 pares de dentes irregulares e pronunciados, na metade superior, 11-19 × 3,9-8,2 $\mathrm{cm}$, cartáceas, quando secas acinzentadas na face adaxial e castanhas na abaxial, glabrescentes a glabras na face adaxial e pubescentes na abaxial, nervuras secundárias 6-9 pares, planas na face adaxial e proeminentes na abaxial, pecíolo canaliculado, 0,7-1,2 cm. Flores estaminadas esverdeadas, em cimas trifloras ou tirsos de 6-12 cimas trifloras, axilares ou terminais, alvopubescentes, raque $0,2-13,3 \mathrm{~cm}$, pedúnculo $1-1,8$ $\mathrm{cm}$, brácteas ovadas, ápice agudo, $3 \mathrm{~mm}$, pedicelo 0,2-0,5 cm, bractéolas ovadas, ápice agudo, $2 \mathrm{~mm}$, 
receptáculo campanulado, 0,3-0,5 cm compr., 0,3-0,4 cm diâm., tépalas $1 / 2$ do compr. da flor, ovadas, externas com ápice arredondado ou agudo, internas com apêndice curto a longo, denticulado; estames 22-44, filetes muito curtos, anteras hipocrepiformes, deiscentes por fenda longitudinal contínua. Flores pistiladas esverdeadas, solitárias ou em tirsos folhosos de até 8 flores, axilares ou terminais, alvo-pubescentes, raque ca. 0,8 $\mathrm{cm}$, pedúnculo 1,5-2,1 cm, brácteas ovadas, ápice agudo, ca. $5 \mathrm{~mm}$, pedicelo $1,5-2,1 \mathrm{~cm}$, bractéolas ovadas, ápice agudo, $3 \mathrm{~mm}$; receptáculo campanulado, ca. 0,3 cm compr., 0,4 cm diâm., tépalas até $1 / 5$ do compr. da flor, ovadas, ápice agudo, externas maiores; carpelos 46-55, 0,11-0,15 cm compr., ovário elíptico, estilete com $1 / 2$ do compr. do carpelo. Drupéolas ovadas, 0,8-0,9 $\times$ ca. 0,6 cm, ápice agudo, estilete persistente, não estipitadas, quando secas marron-acinzentadas, pubescentes, pedúnculo e pedicelo juntos 1,5-3,4 $\mathrm{cm}$, receptáculo frutífero $0,5-1 \mathrm{~cm}$ diâm.

Material selecionado: Águia Branca, Escola Agrotécnica, 5.IX.2006, fl. mas, Magnago 1276 (MBML, RB). Cariacica, Reserva Biológica de Duas Bocas, 21.VII.2008, fr., Amorim 7614 (MBML, RB). Santa Leopoldina, Fazenda Caioaba, propriedade Virloni, 5.I.2006, fl. mas, Magnago 522 (MBML, RB).

Material adicional examinado: BRASIL. BAHIA: Una, Reserva Biológica de Una, lado do Rio Maruim, 28.X.2001, fl. fem, Thomas 12658 (RB, CEPEC, NY).

Ocorre nas Antilhas, Suriname, Guiana, Guiana Francesa, Venezuela, Colômbia, Peru, Equador, Bolívia e Brasil, onde foi coletada nos biomas Amazônia, Caatinga, Cerrado, Pantanal e Mata Atlântica. Há coletas da espécie nos estados do Acre, Amazonas, Roraima, Amapá, Pará, Ceará, Pernambuco, Alagoas, Bahia, Goiás, Minas Gerais, Espírito Santo, Rio de Janeiro, São Paulo e Paraná. É mais freqüente no norte e nordeste do Brasil, sendo as florestas amazônicas (tanto floresta de várzea como de terra firme) e as matas higrófilas sul-baianas onde a espécie é mais freqüentemente coletada. É de ocorrência mais rara no centro-oeste, sudeste e sul (Peixoto \& Santos 2011; BFG 2015). No Espírito Santo ocorre nos municípios de Águia Branca, Conceição do Castelo, Santa Leopoldina e Cariacica, em Floresta Ombrófila Densa Montana.

Os espécimes do Espírito Santo assemelhamse a $M$. schottiana pelo formato das folhas, flores e frutos, no entanto, difere pelo indumento pubérulo e alvo das inflorescências e face abaxial das folhas, e ramos alvo-pubescentes ou glabros (vs. ramos e inflorescências flavescente a ferrugíneo tomentosos e face abaxial das folhas adpresso flavescentes a ferrugíneos em $M$. schottiana). É uma espécie de difícil caracterização pela variação de caracteres (especialmente dimensão foliar e número de estames e carpelos) em sua ampla área de ocorrência e em altitudes muito variadas. Floresce nos meses de maio a julho e foi coletada com frutos em julho. Ocorre em Floresta Ombrófila Densa montana. Coletada com flores em janeiro e setembro e frutos em março, junho, julho e setembro.

3.12. Mollinedia puberula Perkins, Bot. Jahrb. 27: 668, 1900. Tipo: BRASIL. RIO DE JANEIRO: Mendonça 1270 (B, GH). Figs. 10a,b; 13a; 19a Árvore ou arvoreta ou 3-13 m, dióicas, ramos cilíndricos, jovens seríceos, depois glabrescentes. Folhas elípticas, ápice acuminado, raro falcado, tornando a folha um tanto assimétrica, base cuneada, margem inteira ou com 1-5 pares de dentes irregulares no terço superior, 5,6-10 $\times$ 0,7-3,6 cm, papiráceas a levemente cartáceas, discolores, quando secas marrons, face adaxial mais escura, glabrescente, face abaxial mais clara, gríseoseríceas, tricomas adpressos, concentrados na nervura principal, nervuras secundárias 5-8 pares, proeminentes na face abaxial, pecíolo canaliculado, 0,3-0,8 cm. Flores estaminadas amarelas em tirsos de 5-9 cimas trifloras, axilares ou terminais, gríseoseríceas, raque $0,6-2,5 \mathrm{~cm}$, pedúnculo $0,1-0,6$ $\mathrm{cm}$, brácteas oblongas, ápice agudo, 2-2,1 mm, pedicelo $0,1-0,8 \mathrm{~cm}$, bractéolas basais ovadas, ápice arredondado, 1,3-1,4 mm, apicais elípticas, ápice agudo, 2-2,5 mm, flores $0,1-0,25 \mathrm{~cm}$ compr., 0,15-0,3 cm diâm., receptáculo campanulado, tépalas $1 / 3$ do compr. da flor, ovadas, externas com ápice retangular, internas com apêndice longo, inflexo, desiguais, uma com margem truncada outra margem fimbriada; estames 7-13, hipocrepiformes, filetes nulos, deiscentes por fenda longitudinal contínua. Flores pistiladas amarelas, solitárias ou em fascículos de até 2 flores, gríseo-pubérulas, raque e pedúnculo nulos, brácteas oblongas, ápice agudo, presas na base ou no meio do receptáculo, ca. 2,2 mm, pedicelo 0,3-0,4 cm, bractéolas basais ovadas, ápice arredondado, apicais oblongas, ápice agudo, ca. 2,2 mm, basais ovadas, ápice agudo, 1,4 mm; flores 0,3 cm compr., 0,2 cm diâm., receptáculo cupuliforme, internamente griseovelutino, tépalas $1 / 3$ do compr. da flor, ovadas, ápice truncado, margem irregular; carpelos 13 , sésseis, 0,12 cm compr., ovário oblongo, estigma até $1 / 5$ do compr. do carpelo. Drupéolas orbiculares ou elípticas, $1-1,2 \times 0,7-0,9 \mathrm{~cm}$, ápice agudo ou 


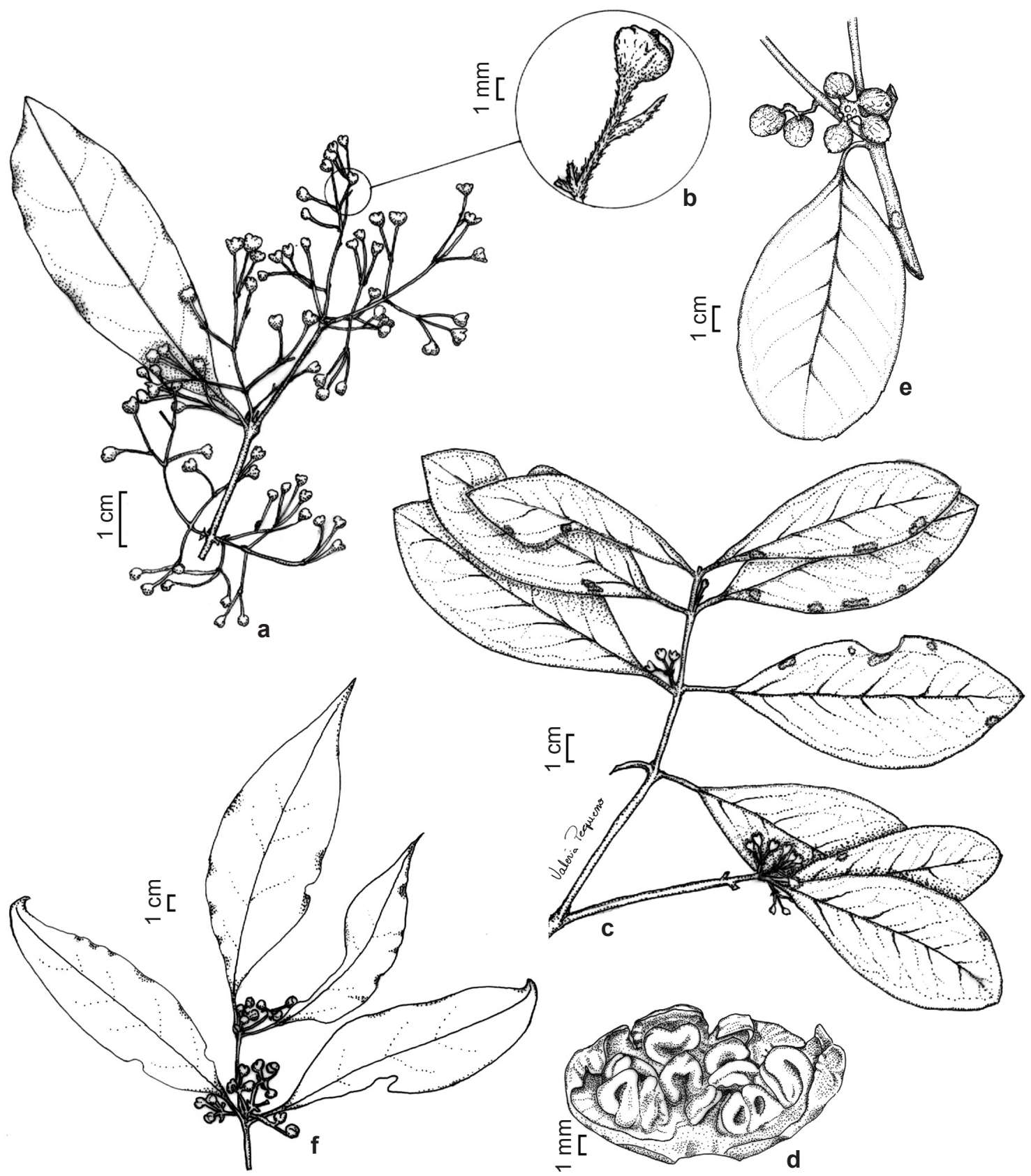

Figura 10 - a,b. Mollinedia puberula - a. inflorescência estaminada; b. detalhe da flor. c-e. Mollinedia salicifolia - c. ramo com flores estaminadas em antese; d. flor estaminada em corte longitudinal; e. ramo com drupéolas. f. Mollinedia uleana - ramo com flores estaminadas. (b. Hatschbach 48618; c. Vervloet 1002; d. Lírio 93; e. Vervloet 2066). Ilustrações: Valéria Pequeno.

Figure 10 - a,b. Mollinedia puberula - a. staminate nflorescence; b. flower detail. c-e. Mollinedia salicifolia - c. branch with staminate flowers in anthesis; d. staminate flower in longitudinal section; e. branch with fruits. f. Mollinedia uleana - stem with staminate flowers. (b. Hatschbach 48618; c. Vervloet 1002; d. Lírio 93; e. Vervloet 2066). Illustrations: Valéria Pequeno. 

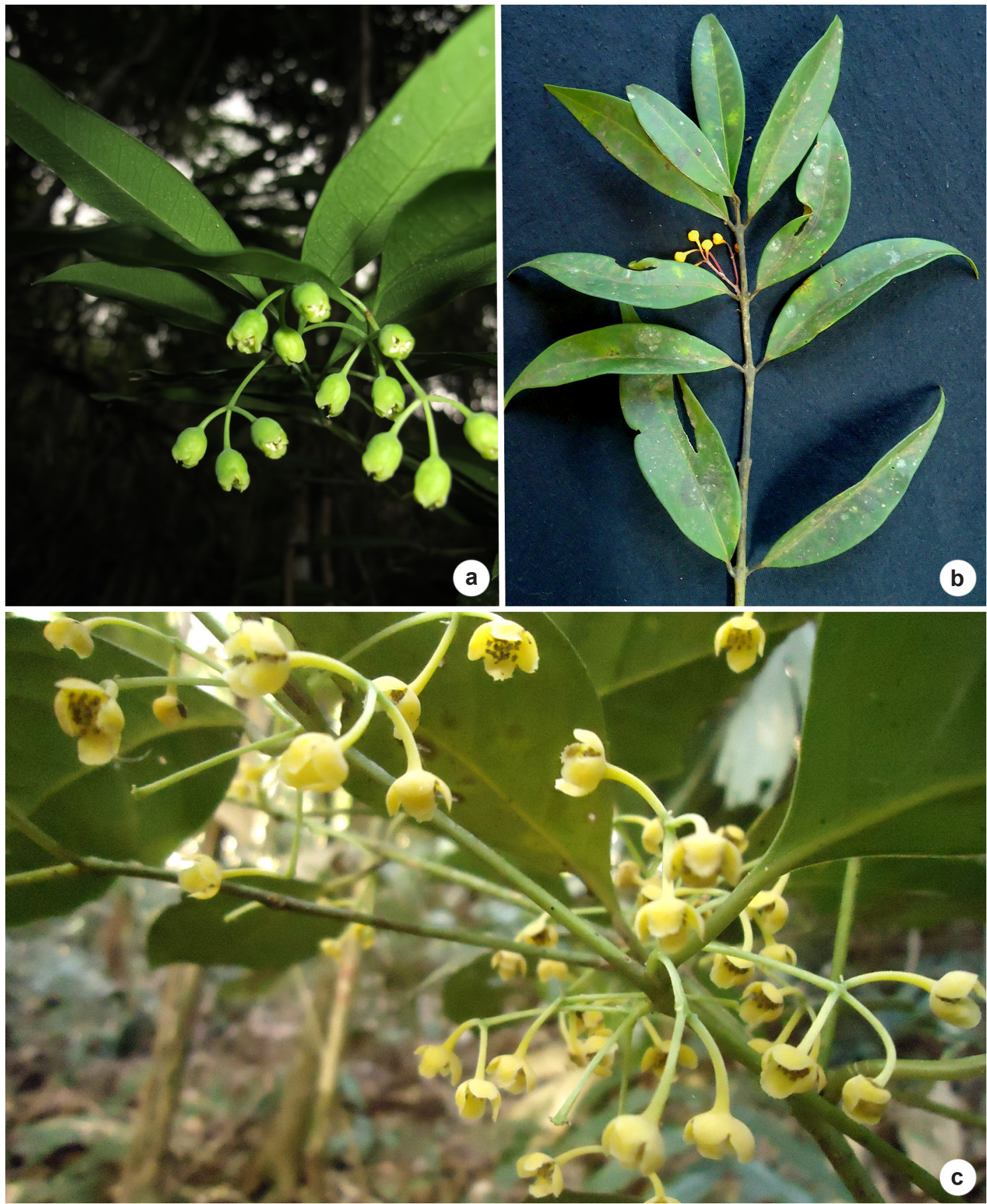

Figura 11 - a. Mollinedia glabra - ramo com flores estaminadas em antese. b. Mollinedia sp. 3 - ramo com flores estaminadas em antese. c. Mollinedia oligantha - ramo com flores estaminadas. (c. Lírio 45). Fotos: a. A.P. Fontana; b,c. E.J. Lírio.

Figure 11 - a. Mollinedia glabra - branch with staminate flowers in anthesis. b. Mollinedia sp. 3-branch with staminate flowers in anthesis. c. Mollinedia oligantha - stem with staminate flowers. (c. Lírio 45). Photos: a. A.P. Fontana; b,c. E.J. Lírio. 
arredondado, estilete persistente, estipitadas ou não, frescas verde-claras, quando secas castanhas, ásperas, pubérulas a glabrescentes, pedúnculo e pedicelo juntos $0,9-1,6 \mathrm{~cm}$, receptáculo frutífero $0,3-0,6 \mathrm{~cm}$ diâm.

Material selecionado: Cariacica, Reserva Biológica de Duas Bocas, 20.VII.2008, fr., Amorim 7584 (MBML, RB). Muniz Freire, Rod. BR-262, 5.X.1984, fl. mas, Hatschbach 48618 (RB). Vargem Alta, estrada para Iconha, Sítio Refúgio Richimond, 7.IX.2012, fl. fem, Lírio 111 (MBML, RB).

Ocorre na Mata Atlântica, nos estados do Rio de Janeiro (BFG 2015) e tem aqui sua distribuição ampliada para o Espírito Santo. No Espírito Santo ocorre em Cariacica, Conceição do Castelo, Santa Teresa, Muniz Freire e Vargem Alta, em floresta ombrófila densa. Foi coletada em duas UCs capixabas: Reserva Biológica de Duas Bocas, em Cariacica e Reserva Biológica Augusto Ruschi (Nova Lombardia), em Santa Teresa.

Difere das demais espécies pelas folhas com tricomas gríseo e adpressos concentrados na nervura principal na face abaxial da folha, inflorescências estaminadas multifloras (1527 flores), flores muito pequenas (1-2,5 mm compr., 1,5-3 mm diâm.) e receptáculo das flores estaminadas campanulado. Coletada com flores em outubro e novembro e frutos de abril, junho, julho e setembro.

3.13. Mollinedia salicifolia Perkins, Bot. Jahrb. Syst. 27: 659, 1900. Tipo: BRASIL. RIO DE JANEIRO: Nova Friburgo, Alto Macaé, 22.IX.1888, fl. mas., Glaziou 17765 (C, F, P! GH, K!).

Figs. 10c-e; 13b,c; 19a

Árvores até $14 \mathrm{~m}$, dióicas, tronco longituginalmente fissurado, finamente suberoso, ramos cilíndricos, fissurados, enegrecidos; ramos jovens com indumento denso, tricomas curtos, alvos, depois glabros. Folhas elípticas ou obovadas, ápice agudo, raro arredondado, base cuneada, margem inteira, raro 2-4 dentes irregulares no terço superior, margem revoluta sob lente, $8,5-17,1$ $\times 4-7,5 \mathrm{~cm}$, coriáceas, discolores, verde-escuras na face adaxial, canescentes na face abaxial, devido ao indumento, secas acinzentadas na face adaxial e acinzentadas a oliváceas na face abaxial, glabras na face adaxial, nervuras secundárias 6-8 pares, pouco aparentes na face adaxial, pouco proeminentes na face abaxial, pecíolo plano na face adaxial, 1,2-1,5 cm. Flores estaminadas amarelas, em tirsos de até 6 cimas trifloras, axilares ou terminais, canescentes, raque 1-1,6 $\mathrm{cm}$, pedúnculo $0,3-0,7 \mathrm{~cm}$, brácteas ovadas, ápice agudo, $0,5-1 \mathrm{~mm}$, pedicelo $0,3-1 \mathrm{~cm}$, bractéolas ovadas, ápice agudo $0,5-1,5 \mathrm{~mm}$; receptáculo cupuliforme $0,4-0,5 \mathrm{~cm}$ compr., $0,3-0,4 \mathrm{~cm}$ diam., tépalas $1 / 3$ do compr. da flor, ovadas, externas com ápice arredondado, margem inteira, internas com ápice obtuso, inflexas, desiguais entre si, uma com margem inteira e outra denticulada; estames 14-16, filetes nulos, anteras hipocrepiformes, deiscentes por fenda longitudinal contínua. Flores pistiladas amarelas, solitárias ou fascículos de até três flores, canescentes, raque $0-1,1 \mathrm{~cm}$, pedúnculo $0,5-0,7 \mathrm{~cm}$, brácteas $0,5-1 \mathrm{~mm}$, pedicelo $0,4-0,5$ $\mathrm{cm}$, bractéolas ovadas, ápice acuminado, 0,5-1,5 $\mathrm{mm}$, receptáculo cupuliforme, $0,5 \mathrm{~cm}$ compr., $0,4 \mathrm{~cm}$ diam., tépalas ovadas, externas com ápice arredondado, internas com apêndice irregular curto, carpelos $8,1,5 \mathrm{~mm}$ compr., ovário oblongo, estigma 1/6 do comprimento do carpelo. Drupéolas orbiculares, ca. 1,7 × 1,4 cm, ápice arredondado, estilete persistente, não estipitadas, quando secas acinzentadas, pericarpo rugoso, espesso, com pubescência esparsa, alva, pedúnculo e pedicelo juntos $0,9-1,9 \mathrm{~cm}$, receptáculo frutífero $0,4-0,9$ cm diâm.

Material selecionado: Santa Maria de Jetibá, Rio Bonito, Fazenda Azaléa, próximo à torre de alta-tensão (Montanha da Paz Celestial), 31.X.2012, fl. mas, Lírio 93 (MBML). Santa Teresa, Nova Lombardia, Reserva Biológica Augusto Ruschi, trilha antiga, sede lado direito, 26.III.2003, fr., Vervloet 2066 (MBML, RB).

Endêmica da Mata Atlântica, ocorre nos estados do Espírito Santo e Rio de Janeiro (BFG 2015). No Espírito Santo foi encontrada apenas no cume de encostas, em Floresta Ombrófila Densa montana nos municípios de Santa Maria de Jetibá e Santa Teresa. Tem ocorrência registrada em duas UCs: Reserva Biológica Augusto Ruschi (Nova Lombardia) e Estação Biológica de Santa Lúcia, ambas em Santa Teresa.

Mollinedia salicifolia se diferencia das demais espécies pelas folhas coriáceas, discolores, face abaxial mais clara, devido a pubescência densa e alva e quando secas se tornam acinzentadas; os ramos frescos apresentam manchas enegrecidas e quando secos, se tornam totalmente enegrecidos. Os espécimes do Espírito Santo se diferenciam daqueles da localidade tipo (Nova Friburgo, Rio de Janeiro) pelas folhas de maior tamanho, elíticas; as folhas dos espécimes da localidade tipo são de menor tamanho e ovadas a oblongas. Foi assinalada na Flora de São Paulo (Peixoto et al. 2002), no entanto, apesar de o espécime citado (K.D. Barreto 3303) apresentar características vegetativas que poderiam permitir a inclusão deste em $M$. salicifolia 

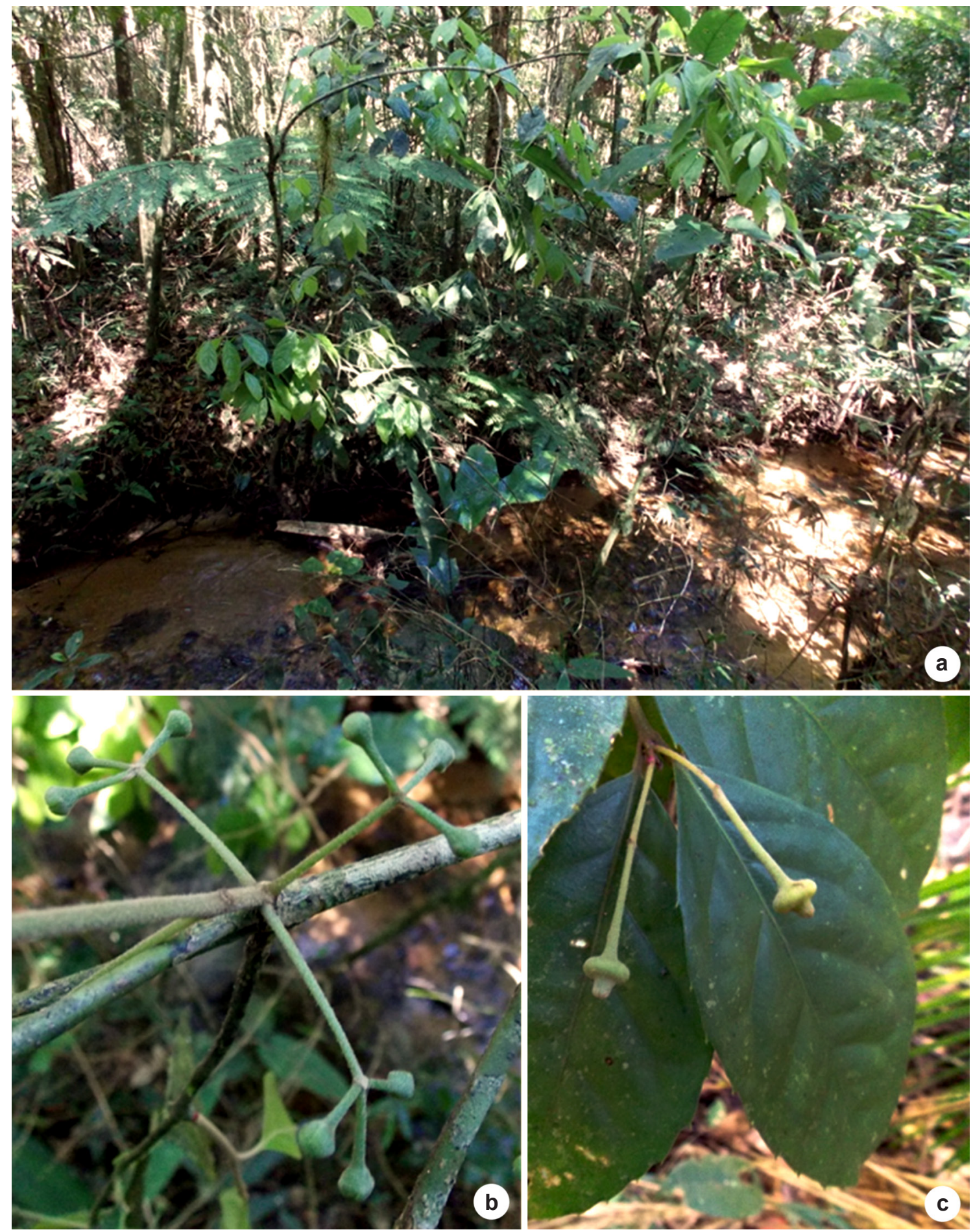

Figura 12 - a-c. Mollinedia ovata - a. hábito; b. espécime estaminado, flores em botão; c. espécime pistilado, flores em pré-antese. (b. Lírio 109; c. Lírio 124). Fotos: J. Rossini.

Figure 12 - a-c. Mollinedia ovata - a. habit; b. staminate specimen, flower buds; c. pistillate specimen, pre-anthesis flowers. (b. Lírio 109; c. Lírio 124). Photos: J. Rossini. 
(como formato e pilosidade das folhas), o fruto, que apresenta caracteres constante na espécie, não corresponde ao da espécie. Coletada com flores de julho a outubro e frutos em março, de maio a agosto e novembro.

3.14. Mollinedia schottiana (Spreng.) Perkins, Bot. Jahrb. 27: 667, 1900. Tipo: BRASIL. "Brasilia Meridionalis, [Rio de Janeiro] Serra Tingua”, 1829, fl. fem e fr., Schott (BR! W, B).

Citriosma schottiana Sprengel, Syst. Veg. 4(2): 407, 1827.

Figs. $15 ; 19 \mathrm{~b}$

Arbustos ou árvores até $7 \mathrm{~m}$, dióicos, ramos cilíndricos, estriados, glabrescentes, os mais jovens achatados, sulcados, tomentosos. Folhas ovadas ou elípticas, ápice agudo ou acuminado, base aguda, cuneada ou obtusa, 5-10 pares de dentes irregulares na metade ou no terço superior, dentes pouco a muito pronunciados, $7,3-12,7 \times 2,7-4,8$ $\mathrm{cm}$, cartáceas, discolores, secas verde-escuras ou marrons na face adaxial e castanhas na abaxial, glabras na face adaxial e adpresso-flavescentes ou ferrugínea na face abaxial principalmente na nervura principal, nervuras secundárias 6-8 pares, pouco aparentes na face adaxial, pouco proeminentes na abaxial, pecíolo canaliculado, 0,6$1,1 \mathrm{~cm}$. Flores estaminadas amarelas em fascículos de 3-6 cimas trifloras, axilares, ferrugíneotomentosas, raque $0-0,38 \mathrm{~cm}$, pedúnculo $0-1,8$ $\mathrm{cm}$, brácteas obovadas, ápice arredondado, 1,6-1,9 $\mathrm{mm}$, pedicelo $0,5-1,3 \mathrm{~cm}$, bractéolas ovadas, ápice agudo, 1,1-1,9 mm; receptáculo campanulado, 0,38-0,48 cm compr., 0,36-0,6 cm diâm., tépalas $1 / 2$ do compr. da flor, ovadas, externas com ápice emarginado, internas com ápice inflexos, apêndice longo, fimbriado; estames 30-42, filetes nulos, anteras hipocrepiformes, deiscentes por fenda longitudinal contínua. Flores pistiladas amarelas solitárias ou em fascículos de até 3 flores, axilares ou terminais, tomentosas, raque nula, pedúnculo $0,35-1,8 \mathrm{~cm}$, brácteas caducas, pedicelo ca. 0,51 $\mathrm{cm}$, bractéolas ovadas, ápice agudo, 1,2-1,4 mm, receptáculo cupuliforme, internamente flavescentevelutino, $0,45-0,48 \mathrm{~cm}$ compr., $0,47-0,68 \mathrm{~cm}$ diâm., tépalas $1 / 3$ do compr. da flor, ovadas, externas com ápice agudo, internas com ápice truncado, inteiro ou brevemente denteado; carpelos 58-64, 0,11-0,15 cm compr., ovário obovado, $1 / 2-1 / 4$ do compr. do carpelo. Drupéolas elípticas, raro orbiculares, ca. $0,8 \times 0,5-0,6 \mathrm{~cm}$, ápice agudo, estilete persistente, não estipitadas, quando secas marrons, pubescentes, pedúnculo e pedicelo juntos $1,5-3,6 \mathrm{~cm}$, receptáculo frutífero $0,6-0,9 \mathrm{~cm}$ diâm.
Material selecionado: Cariacica, Reserva Biológica de Duas Bocas, Alegre, trilha do Pau Oco, 18.I.2009, fl. mas, Labiak 5180 (MBML, RB, UPCB). Santa Teresa, São Lourenço, terreno de Clerio Loss, Mata Fria, lado direito, 18.VIII.2004, fr., Kollmann 6947 (MBML, RB).

Endêmica da Mata Atlântica, nos estados Bahia, Minas Gerais, Espírito Santo, Rio de Janeiro, São Paulo, Paraná, Santa Catarina e Rio Grande do Sul (BFG 2015). No Espírito Santo tem ocorrência registrada nos seguintes municípios: Cariacica e Santa Teresa, Santa Maria de Jetibá, Castelo, Conceição de Castelo, Ibitirama e Iúna. Ocorre em Floresta Ombrófila Densa montana e alto-montana, no interior ou em borda de florestas, em áreas bem conservadas ou em regeneração, e em inserbergs. Tem ocorrência registrada em duas UCs: Reserva Biológica de Duas Bocas, em Cariacica e Parque Estadual de Forno Grande, em Castelo.

Mollinedia schottiana tem caracteres muito variáveis e é facilmente confundida com outras espécies. Assemelha-se a M. longifolia devido à pilosidade, diferencia-se por esta apresentar folhas três vezes mais compridas em relação à largura, tépalas com $1 / 3$ do compr. da flor e estames basais com filetes curtos e apicais mais longos (vs. folhas com comprimentos nunca três vezes maior que a largura, tépalas com $1 / 2$ do compr. da flor e estames com filetes nulos). Assemelha-se a $M$. ovata pelo formato das folhas, flores e frutos, mas diferencia-se desta pela pilosidade flavescente-tomentosos dos ramos e inflorescências e adpresso-fulvescente na face abaxial das folhas (vs. ramos alvo-pubescentes ou glabros e inflorescências e face abaxial das folhas alvopubescentes). Assemelha-se a Mollinedia sp. 1 pelo porte e formato das folhas, mas diferencia-se pelos ramos tomentosos, receptáculo campanulado, maior número de estames (30-42) e drupéolas marrons quando secas (vs. ramos com pilosidade adpressa, receptáculo plano, menor número de estames (10-14) e drupéolas amareladas quando secas em Mollinedia sp. 1). Ocorre no interior ou em borda, em Floresta Ombrófila Densa montana. Coletada com flores em janeiro, fevereiro, março e maio e frutos em fevereiro, junho, julho, agosto e outubro.

3.15. Mollinedia sphaerantha Perkins, Bot. Jahrb. Syst. 27: 660, 1900. Tipo: BRASIL. RIO DE JANEIRO: Rio de Janeiro, Corcovado, Cova da Onça, 12.IX.1867, fl. mas, Glaziou 1521 (P! BR! B, C, F, GH). Figs. 14a-d; 19b Arbustos a arvoretas 0,6-2 m, monóica ou dióica, ramos cilíndricos, estriados, pubescentes ou glabrescentes. Folhas largamente elíticas ou 


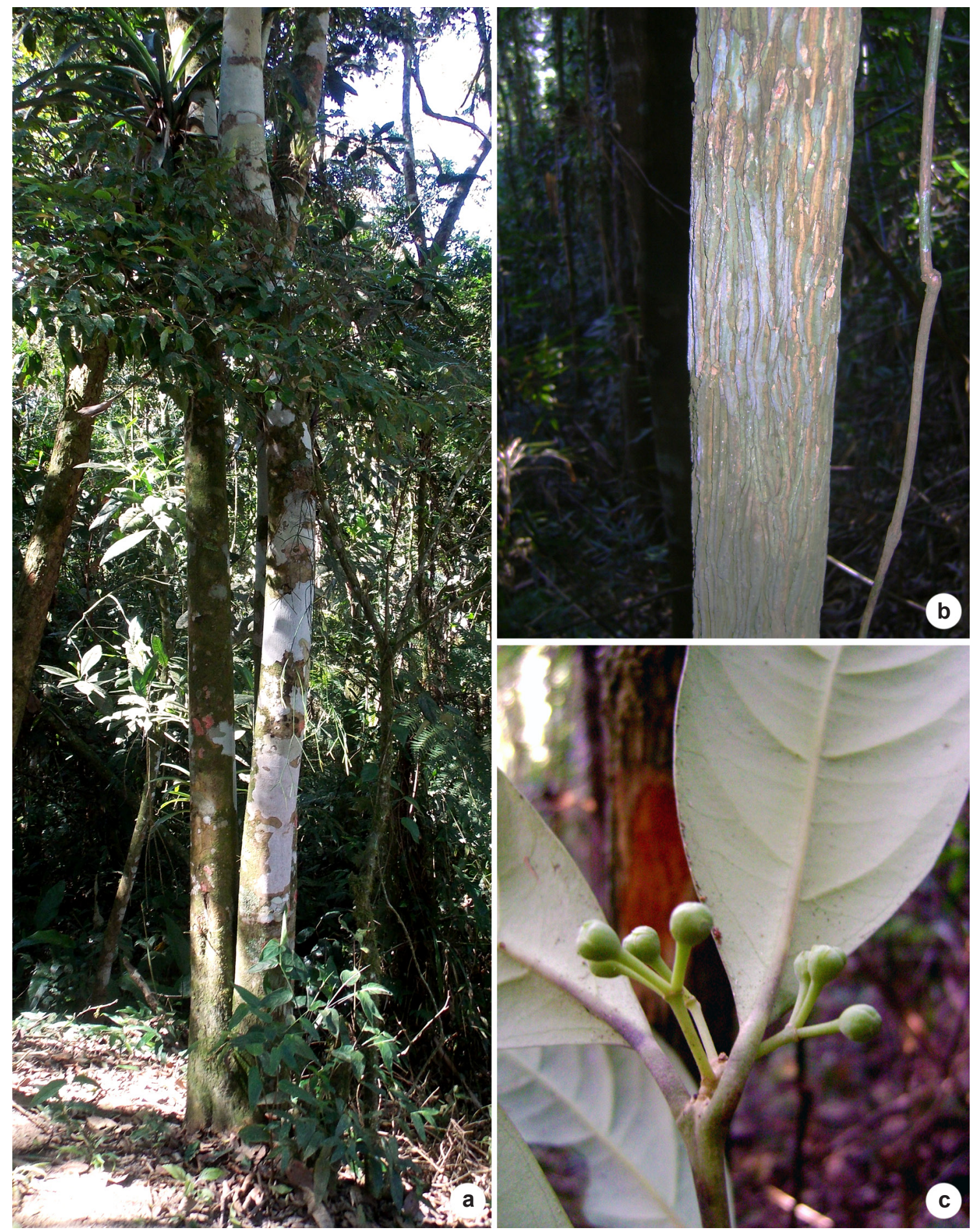

Figura 13 - a. Mollinedia puberula - hábito. b,c. Mollinedia salicifolia - b. tronco; c. ramo com flores estaminadas em botão. (a. Lírio 111; c. Lírio 93). Fotos: a. J. Rossini; b.c. E.J. Lírio.

Figure 13 - a. Mollinedia puberula - habit. b,c. Mollinedia salicifolia - b. stem; c. branch with bud flowers. (a. Lírio 111; c. Lírio 93). Photos: a J. Rossini, b-c E. J. Lírio. 
oblongas, ápice acuminado, raro falcado, base obtusa ou cuneada, 3-9 pares de dentes irregulares no terço superior, pouco pronunciados, margem revoluta sob lente, $8,2-19,4 \times 3,1-9,5 \mathrm{~cm}$, coriáceas ou rígidocartáceas, oliváceas a castanho-claras, nítidas, pelúcido-pontuadas, glabras ou glabrescente na face adaxial, pubescentes na face abaxial, especialmente no terço onferior, nervuras secundárias 9-13 pares, imersos na face adaxial, pouco proeminentes na abaxial; pecíolo canaliculado, $0,7-1,7 \mathrm{~cm}$. Flores estaminadas amarelas em tríades ou fascículos de 2 tríades terminais, pubescentes, raque nula, pedúnculo ca. $2,3 \mathrm{~cm}$, brácteas caducas, pedicelo $0,6 \mathrm{~cm}$, bractéolas ovadas, ápice agudo, ca. $2 \mathrm{~mm}$, receptáculo urceolado, ca. $0,8 \mathrm{~cm}$ compr., 0,8 $\mathrm{cm}$ diâm., tépalas $1 / 4$ do compr. da flor, ovadas, externas com ápice agudo, internas com ápice arredondo, desiguais, uma com margem inteira, outra denticulada, estames 24-29, filetes dos estames basais mais longos, apicais curtos, anteras hipocrepiformes, deiscentes por fenda longitudinal contínua. Flores pistiladas amarelas, solitárias, terminais, pubescentes, raque nula, pedúnculo ca. $0,55 \mathrm{~cm}$, brácteas lanceoladas, ápice agudo, 1,9-2 $\times$ 0,9-1 mm, pedicelo ca. $0,3 \mathrm{~cm}$, bractéolas ovadas, ápice agudo, 1-1,9 $\mathrm{mm}$, receptáculo cupuliforme, internamente velutino, ca. $0,4 \mathrm{~cm}$ compr., $0,3 \mathrm{~cm}$ diâm., tépalas quase iguais entre si; carpelos 12-26, ca. 0,2 cm compr., ovário oblongo, estilete com $1 / 4$ do compr. do carpelo. Drupéolas elípticas, ca. $1,3 \times 0,8 \mathrm{~cm}$, ápice agudo, estilete persistente, não estipitadas, maduras avermelhadas ou vináceas, secas marron-claras, pubescentes, pedúnculo e pedicelo e juntos ca. $1,1 \mathrm{~cm}$, receptáculo frutífero $0,5-0,7 \mathrm{~cm}$ diâm.

Material selecionado: Atílio Vivacqua, Moitão, Serra das Torres, 19.I.2008, fl. fem e fr., Kollmann 10332 (MBML, RB). Linhares, Reserva Natural Vale, Estrada Jueirana Vermelho, Km 2,4 antes da casa da guarda, 20.IV.2011, fr., Lopes 293 (RB, ESA). Santa Maria de Jetibá, Fazenda Azaléa, abaixo da torre de transmissão, entrada pelo cafezal, Rio Bonito, 13.VIII.2012, fr., Lírio 86 (RB).

Endêmica da Mata Atlântica, ocorre no Rio de Janeiro e Espírito Santo (BFG 2015). Foi registrada nos municípios de Linhares, Cariacica, Santa Teresa, Santa Maria de Jetibá e Atílio Vivacqua. Tem ocorrência nas matas de tabuleiros e na Floresta Ombrófila densa, em três UCs: Reserva Biológica Augusto Ruschi (Nova Lombardia) e Estação Biológica Santa Lúcia, em Santa Teresa e na Reserva Natural Vale, em Linhares.

Mollinedia sphaerantha assemelha-se a $M$. glabra pelo porte arbustivo, coloração e pontuação das folhas e formato do receptáculo das flores estaminadas. No entanto, diferencia-se pela pubescência apresentada pelos pecíolos, folhas e flores, ausente em M. glabra; a consistência e tamanho das folhas também é relevante para a diferenciação destas espécies: as folhas de $M$. sphaerantha são coriáceas e de maiores dimensões, e as de M. glabra papiráceas a cartáceas e de menores dimensões, no entanto, quando em afloramentos rochosos, M. glabra pode apresentar folhas coriáceas. $M$. sphaerantha é frequentemente encontrada em populações agregadas, em interiores de matas úmidas e bem conservadas e às margens de cursos d'água em floresta. Alguns indivíduos nas populações de Santa Maria de Jetibá e Atílio Vivacqua apresentaram monoicia, um caráter até então inesperado para as Monimiaceae neotropicais. Encontrada com flores em janeiro, fevereiro, junho e agosto e frutos em janeiro, março, abril, junho, agosto, outubro e dezembro.

3.16. Mollinedia uleana Perkins Bot. Jahrb. Syst. 27: 661, 1900. Tipo: BRASIL. SANTA CATARINA: Blumenau, Itajaí, IX.1855, fl. mas, Ule 505 (GH, B).

Figs. 10f; 19c

Árvores até $11 \mathrm{~m}$, dióicas, ramos cilíndricos, levemente estriados, jovens tomentosos ou velutinos, depois glabrescentes. Folhas elípticas, ápice agudo ou acuminado, base aguda ou cuneada, margem inteira ou com 3-7 pares de dentes irregulares no terço superior, dentes pouco pronunciados, 11-17 × 3,1-6,2 cm, cartáceas, sem pontuações aparentes, castanhas, glabrescentes na face adaxial e velutinas na abaxial, principalmente na nervura principal, nervuras secundárias 7 pares, pouco aparentes na face adaxial, proeminentes na abaxial, pecíolo canaliculado, 0,9-1,5 cm. Flores estaminadas verde-claras, em tirsos de 3-5 cimas trifloras, axilares ou terminais, áureo-tomentosas, raque $0-0,3 \mathrm{~cm}$, pedúnculo $0,7-0,9 \mathrm{~cm}$, brácteas ovadas, ápice agudo, ca. $2 \mathrm{~mm}$, pedicelo $0,3-0,6$ $\mathrm{cm}$, bractéolas ovadas, ápice agudo, ca. $2 \mathrm{~mm}$, receptáculo plano, ca. 0,2 cm compr., $0,4 \mathrm{~cm}$ diâm., tépalas $1 / 2$ do compr. da flor, ovadas, externas ápice arredondado, desiguais, uma maior, internas desiguais, uma maior, com apêndice curto, denticulado, outra com apêndice muito curto, ápice truncado; estames 19, filetes muito curtos, anteras hipocrepiformes, deiscentes por fenda longitudinal contínua. Flores pistiladas solitárias ou em fascículos de 2-4 flores, tomentosas, terminais, raque nula, pedúnculo $1-1,4 \mathrm{~cm}$, bractéas ovadas, ápice agudo, ca. $2 \mathrm{~mm}$, pedicelo 

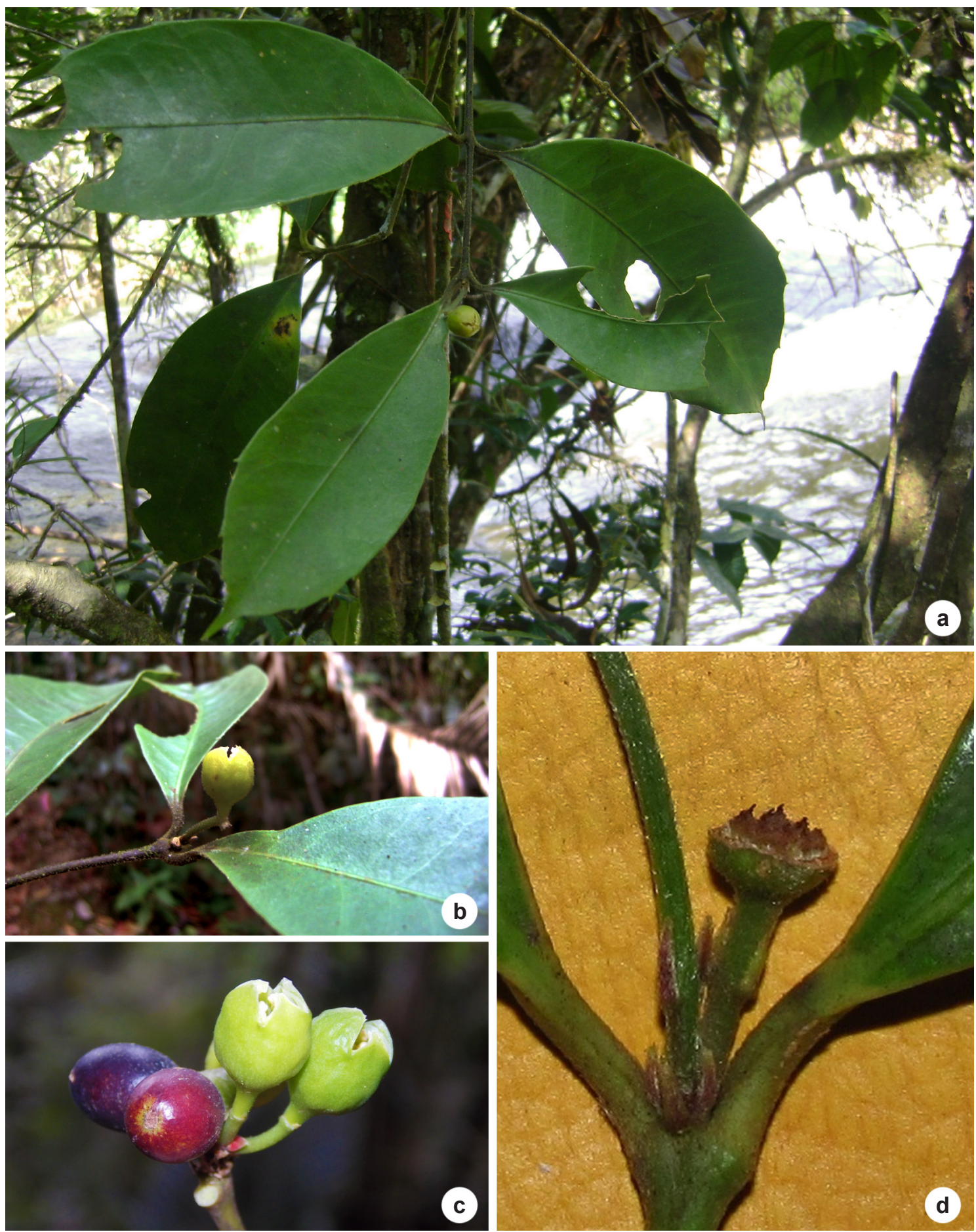

Figura 14 - a-d. Mollinedia sphaerantha - a. hábito; b. ramo com flor estaminada, vista frontal; c. ramo com frutos maduros e flores estaminadas em antese; d. flor pistilada após queda da caliptra. (b. Lírio 56; c. Lírio 1277; d. Lírio 176). Fotos: E.J. Lírio.

Figure 14 - a-d. Mollinedia sphaerantha - a. habit; b. branch with staminate flower, frontal view; c. branch with ripe fruits and staminate flowers in anthesis; d. pistillate flower pistilada after calyptra fall. (b. Lírio 56; c. Lírio 1277; d. Lírio 176). Photos: E.J. Lírio. 

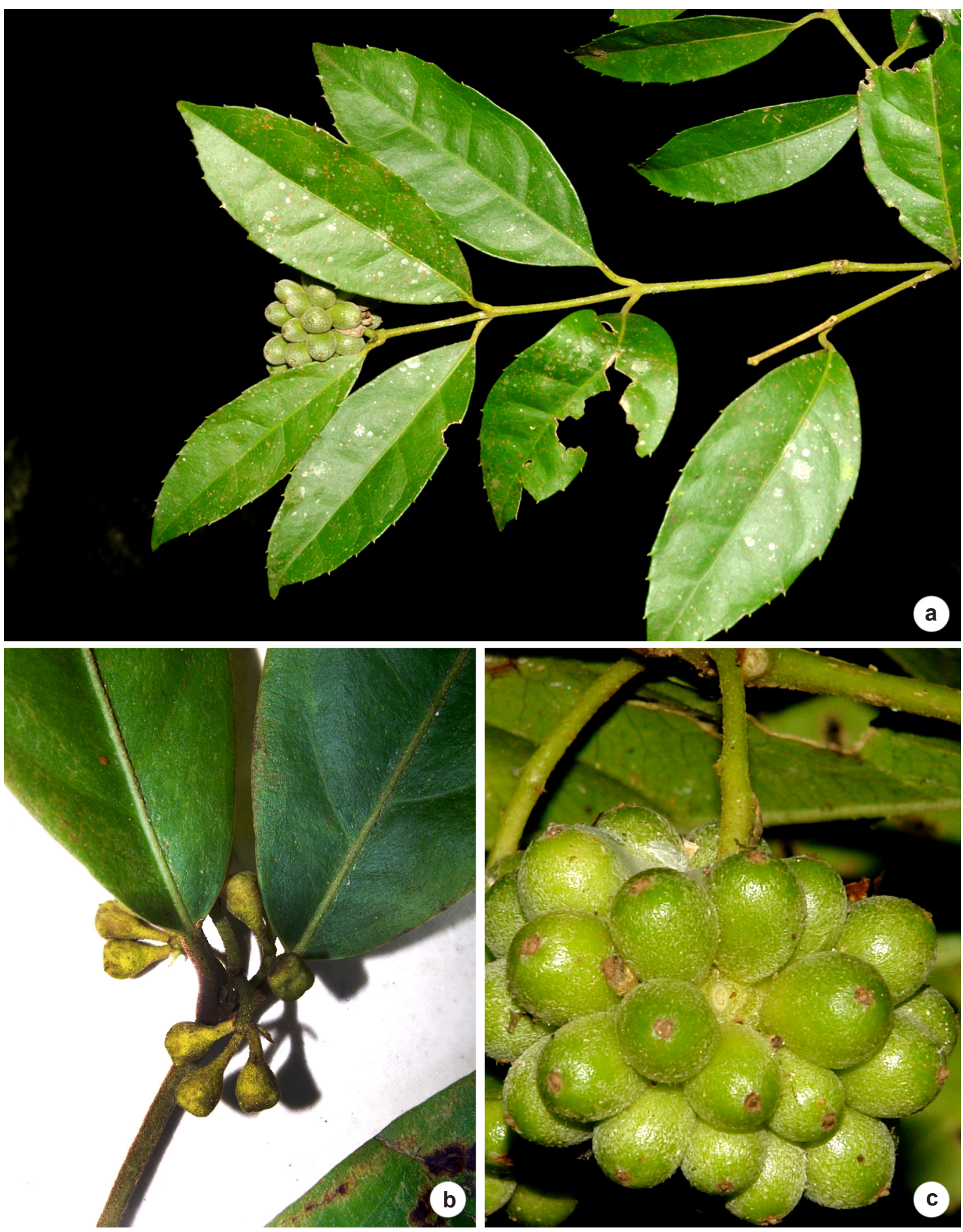

Figura 15 - a-c. Mollinedia schottiana - a. ramo com drupéolas; b. ramo com flores estaminadas; c. detalhe das drupéolas. (a,c. Fraga 2159; b. Lírio 115). Fotos: a,c. C.N. Fraga; b. E.J. Lírio.

Figure 15 - a-c. Mollinedia schottiana - a. branch with druplets; b. branch with staminate flowers; c. fruits detail. (a,c. Fraga 2159 ; b. Lírio 115). Photos: a,c. C.N. Fraga; b. E.J. Lírio. 
0,8-1 cm, bractéolas ovadas, ápice agudo, ca. $1 \mathrm{~mm}$, receptáculo campanulado, internamento velutino, 0,3-0,6 compr., ca. 0,3 cm diâm., tépalas quase iguais entre si, capelos 14-16, flavescentetomentoso, 0,2 cm compr., ovário oblongo, estilete com 1/4 do compr. do carpelo. Drupéolas elípticas, ca. 1,9 $\times 1,1 \mathrm{~cm}$, ápice agudo, estilete persistente, não estipitadas, quando secas castanhas, velutinas, pedúnculo e pedicelo juntos $1,8-3 \mathrm{~cm}$, receptáculo frutífero ca. $0,8 \mathrm{~cm}$ diâm.

Material selecionado: Santa Teresa, Aparecidinha, terreno de Luiz Bringhenti, 28.I.1999, fr., Kollmann 1740 (MBML, RB); Santo Henrique, propriedade do senhor Valdecir Freire, A1P10, 16.IX.2005, bot. mas, Britto 69 (MBML, RB).

Material adicional selecionado: BRASIL. PARANÁ: Curitiba, Praça Osório, 28.II.2016, fr., Lírio \& Karnos 1337 (RB). SÃO PAULO: São Paulo, Butantan, 22.X.1918, fl. fem, Hoehne (RB 418921). SANTA CATARINA: Pirahy-Mirim, 19.IX.1897, fl. fem e fr., Schwacke 13198 (RB).

Endêmica da Mata Atlântica, ocorre em Santa Catarina, Paraná, São Paulo, Rio de Janeiro e Espírito Santo (BFG 2015). Conhecida para o Espírito Santoapenas de dois espécimes coletados em Santa Teresa, em Floresta Ombrófila Densa montana. No estado não foi encontrada em UC. Coletada com flores em setembro e frutos em janeiro.

Assemelha-se a $M$. argyrogyna da qual é distinta pelas folhas velutinas, de maiores dimensões e sem cicatrizes de tricomas espessadas e frutos velutinos e pedúnculo e pedicelo frutíferos de maiores dimensões (folhas tometosas, de menores dimensões e com cicatrizes de tricomas espessadas, frutos tomentosos a glabrescentes, pedúnculo e pedicelo frutíferos de menores dimensões em $M$. argyrogyna). Coletada com flores em setembro e frutos em janeiro.

\subsection{Mollinedia sp. 1.}

Figs. 16; 19c

Arbustos a arvoretas, 3-9 m, dióicos, ramos cilíndricos, estriados, adpresso-tomentosos depois glabrescentes. Folhas elípticas, ápice obtuso a longo acuminado, geralmente falcado, base aguda, raro cuneada, margem com 4-6 pares de dentes irregulares, na metade superior, 7,3-15,5 × 1,2-5,5 $\mathrm{cm}$, cartáceas, discolores, quando secas oliváceas, nítidas em ambas as faces, pelúcido-pontuadas, jovens com pilosidade adpressa, alva, em ambas as faces, depois glabrescentes, ou glabras na face adaxial; nervuras secundárias 6-10 pares aparentes na face adaxial e proeminentes na abaxial, pecíolo canaliculado, 0,5-1,8 cm. Flores estaminadas amarelo-claro, em tirsos ou fascículos de até cinco cimas trifloras, axilares ou terminais, alvopubérulas, raque $0-1 \mathrm{~cm}$, pedúnculo $0,3-0,8 \mathrm{~cm}$, brácteas ovadas, ápice agudo, ca. $9 \mathrm{~mm}$, pedicelo 0,2-1,3 cm, bractéolas ovadas, ápice agudo, ca. $0,11 \mathrm{~mm}$; receptáculo plano, 0,2-0,5 cm compr., 0,2-0,5 cm diâm., tépalas $4 / 5$ do compr. da flor, externas ovadas ou oblongas, ápice agudo, internas oblongas, ápices arredondados, desiguais, uma com margem inteira, outra denteada, estames 10-14, hipocrepiformes, com filetes muito curtos, anteras deiscentes por fenda longitudinal. Flores pistiladas verde-claras, solitárias ou em fascículos de até 6 flores, raque $0-0,65 \mathrm{~cm}$, pedúnculo $0-0,5$ $\mathrm{cm}$, brácteas ovadas, ápice agudo, 1,1-1,5 mm, pedicelo $0,4-1,3 \mathrm{~cm}$, bractéolas ovadas, ápice agudo, 1,5-1,8 $\mathrm{mm}$, receptáculo cupuliforme, internamente ferrugíneo-velutino, $0,3-0,5 \mathrm{~cm}$ compr., 0,4-0,5 cm diâm., tépalas $1 / 3$ do compr. da flor, externos ovados, ápice arredondado, margem inteira, internos oblongos, ápice truncado, margem irregular; carpelos 11-22, com 0,2-0,21 cm compr., ovário oblongo ou elíptico, estilete 1/4-1/2 do compr. do carpelo. Drupéolas elípticas ou orbiculadas, $1,3-2,1 \times 0,9-1,3 \mathrm{~cm}$, ápice arredondado, estilete persistente, não estipitadas, vináceas quando maduras, oliváceas quando secas, rígidas, ásperas, alvo-pubérulas, pedúnculo e pedicelo juntos $0,6-1,1 \mathrm{~m}$, receptáculos frutíferos 0,4-0,8 cm diâm.

Material selecionado: Santa Teresa, Estação Biológica de Santa Lúcia, topo do morro, ao lado da P15-A3 de L. Thomaz, 8.VII.2011, fl. mas, Lírio 34 (MBML, RB).

Conhecida na Floresta Ombrófila Densa montana no município de Santa Teresa e também para Teresópolis, RJ. No Espírito Santo ocorre na Mata da Penha e em Santo Antônio, na UC Estação Biológica de Santa Lúcia.

A espécie assemelha-se vegetativamente a M. fruticulosa Perkins (1900) pelo porte e formato das folhas, entretanto, diferencia-se pelas flores estaminadas com receptáculo plano (campanulado em M. fruticulosa). Dentre as espécies que ocorrem no Espírito Santo, assemelha-se a $M$. schottiana pelo formato das folhas, mas diferenciase desta pelos ramos com pilosidade adpressa, receptáculo plano, menor número de estames (10-14) e drupéolas amareladas quando secas (vs. ramos tomentosos, receptáculo campanulado, maior número de estames (30-42) e drupéolas marrons quando secas). Coletada com flores de junho a setembro e frutos em outubro, dezembro e de janeiro a março. 


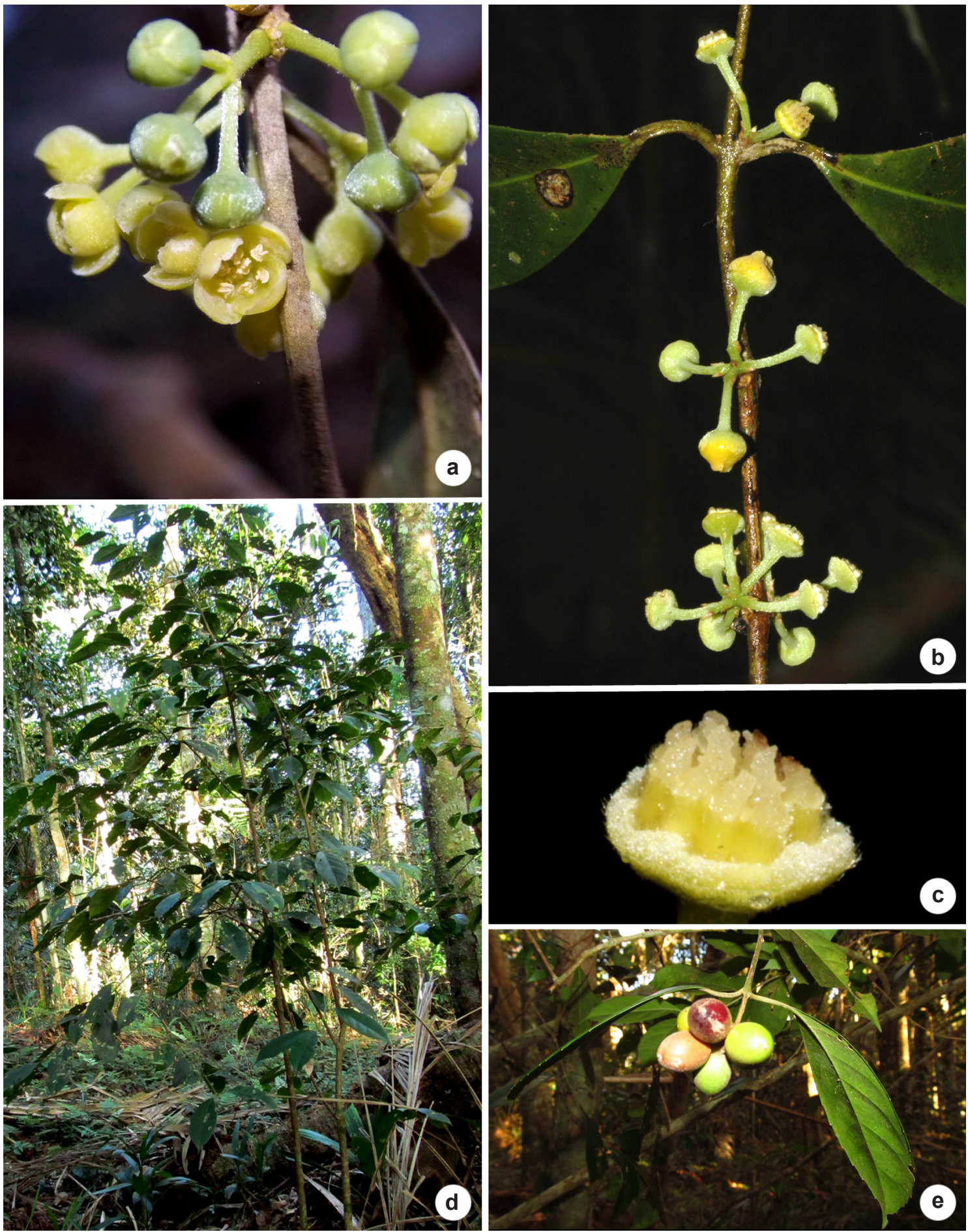

Figura 16 - a-e. Mollinedia sp. 1 - a. ramo com flores estaminadas; b. ramo com flores pistiladas em antese; c. flor pistilada após deiscência da caliptra, exibindo os carpelos; d. hábito; e. ramo com drupéolas. (a. Lírio 1276; e. Lírio 186). Fotos: a. E.J. Lírio; d,e. V. Sarnaglia; b,c. C.N. Fraga.

Figure 16 - a-e. Mollinedia sp. 1 - a. branch with staminate flowers; b. branch with pistillate flowers in anthesis; c. pistillate flower after calyptra falls, showing the carpels; d. habit; e. brach with fruits. (a. Lírio 1276; e. Lírio 186). Photos: a. E.J. Lírio; d,e. V. Sarnaglia; b,c. C.N. Fraga. 


\subsection{Mollinedia sp. 2.}

Figs. 17; 19d

Árvores 6-15 m, dióicas, ramos subcilíndricos, delgados, glabros. Folhas elípticas, ápice acuminado, raro falcado, base aguda, inteiras, 3,9-10,4 × 1,5-3,8 cm, cartáceas, sem pontuações aparentes, castanhas quando secas, glabras, nervuras secundárias 11-14 pares, pouco aparentes na face adaxial, proeminentes na abaxial; pecíolo canaliculado, $0,5-0,8 \mathrm{~cm}$. Flores estaminadas amereladas, pruinosas, arranjadas em tirsos axilares ou terminais de 4-6 tríades glabras, exceto nas brácteas, raque $0,3-0,4 \mathrm{~cm}$, pedúnculo $0,8-1,1$ $\mathrm{cm}$, brácteas ovadas, ápice agudo, pubescentes, 1,1 $\mathrm{mm}$, pedicelo $0,6-1 \mathrm{~cm}$, bractéolas ovadas, ápice agudo, $1,1 \mathrm{~mm}$; receptáculo ca. $0,34 \mathrm{~cm}$ compr., ca. $0,55 \mathrm{~cm}$ diâm., receptáculo plano, tépalas $1 / 4$ do compr. da flor, ovadas, externas ápice arredondado, internas ápice truncado, desiguais, uma com margem inteira outro denticulada; estames 13-17, distribuídos no receptáculo, filetes nulos, anteras hipocrepiformes, deiscentes por fenda longitudinal contínua. Flores pistiladas não examinadas. Drupéolas elípticas, ca. 1,6×0,9 cm, ápice agudo, estilete persistente, quando maduras avermelhadas, secas castanhas, glabras, ásperas, pedicelo e pedúnculo juntos $0,7-1,3 \mathrm{~cm}$, receptáculo frutífero pubescente, $0,23-0,65 \mathrm{~cm}$ diâm.

Material selecionado: Muniz Freire, Arredores, 15.X.1983, fl. mas, Hatschbach 46881 (MBML, RB, ALCB, MBM, CESJ, ESA, FUEL). Santa Teresa, São Lourenço, Estação Biológica da Caixa d'Água, 30.XI.1999, fl. mas, Demuner 270 (MBML, RB). Nova Lombardia, Reserva Biológica Augusto Ruschi, trilha da cachoeira a partir da Sede Nova, 19.VIII.2003, fr., Rossini 460 (MBML, RB).

Conhecida para Espírito Santo e sul da Bahia. No Espírito Santo tem ocorrência registrada em dois municípios: Santa Teresa e Muniz Freire. Ocorre em três UCs, todas no município de Santa Teresa, em Floresta Ombrófila Densa Montana: São Lourenço, Estação Biológica da Caixa d'Água, Reserva Biológica Augusto Ruschi (Nova Lombardia) e Estação Biológica de Santa Lúcia.

Assemelha-se a M. oligantha pelas folhas glabras e receptáculo plano e pruinoso, no entanto, se diferencia pelas folhas de menores dimensões, castanhas, base aguda e ápice atenuado, nervuras secundárias 11-14 pares (folhas de maiores dimensões, oliváceas, base cuneada, ápice acuminado, nervuras secundárias 5-7 pares em $M$. oligantha). Foram encontrados em algumas flores (Demuner 270) estames mais externos menores e aparentemente mal formados. Coletada com flores de setembro a novembro e frutos em maio e agosto.
3.19. Mollinedia sp. 3 .

Figs. 11b; 19d

Árvore 7-15 m alt., dióicas, ritidoma espesso, gretado, ramos castanhos, enegrecidos ou acinzentados, cilíndricos a subcilíndricos, longitudinalmente estriados, glabros. Folhas elípticas a oblongas, ápice atenuado, frequentemente falcado, base cuneada, raro aguda, margem inteira ou com até 2 dentes irregulares no terço superior, pouco pronunciados, $6,5-13,5 \times 1,2-3,8 \mathrm{~cm}$, subcoriáceas, discolores, frescas verde-escuras na face adaxial e verde-claras na abaxial, odoríferas, quando secas marrons, pelúcido-pontuadas, opacas, glabras em ambas as faces, nervuras secundárias 9-13 pares, pouco aparentes na face adaxial, proeminentes na face abaxial, pecíolos canaliculados, $0,6-1,8 \mathrm{~cm}$. Flores estaminadas alaranjadas, em tirsos de 2-6 cimas trifloras, axilares ou terminais, esparso-pubérulas, raque 0,2-1,1 $\mathrm{cm}$, pedúnculo $0,4-1,4 \mathrm{~cm}$, brácteas ovadas, ápice agudo, $0,7-0,8 \mathrm{~mm}$, pedicelo $0,2-1,3$ $\mathrm{cm}$, bractéolas ovadas, ápice agudo, $1-1,5 \mathrm{~mm}$, receptáculo campanulado, $0,5-0,6 \mathrm{~cm}$ compr., ca. $0,5 \mathrm{~cm}$ diâm., tépalas $2 / 3$ do compr. da flor, ovadas, externas com ápice arredondado, margem irregular, internas inflexas, desiguais, uma com apêndice curto, margem fimbriada, outra com apêndice longo, margem denticulada; estames $12-15$, filetes nulos, anteras hipocrepiformes, deiscentes por fenda longitudinal contínua. Flores pistiladas desconhecidas. Drupéolas elípticas ou orbiculadas, $0,8-2 \times 1,2 \mathrm{~cm}$, estilete persistente, estipitadas, quando secas marrons, pericarpo rugoso, glabro, pedúnculo e pedicelo juntos 0,9-2,4 $\mathrm{cm}$, receptáculo frutífero com $0,5-1 \mathrm{~cm}$ diâm.

Material selecionado: Governador Lindenberg, Santa Luzia, Firmino, 2.VIII.2007, fr., Vervloet 3132 (MBML). Santa Teresa, Estação Biológica de Santa Lúcia, 28.VI.2011, fl. mas, Lírio 20 (MBML).

Conhecida de exemplares coletados nos municípios de Governador Lindenberg (um espécime) e Santa Teresa (11 espécimes, todos na Estação Biológica Santa Lucia e na Reserva Biológica Augusto Ruschi), no cume de encostas em Floresta Ombrófila Densa montana.

Táxon conhecido apenas de exemplares com flores masculinas ou em frutos. Assemelha-se a $M$. stenophylla pelo formato das folhas, entretanto diferencia-se pelo porte arbóreo, folhas opostas e receptáculo das flores estaminadas campanulado (porte subarbustivo, folhas verticiladas e receptáculo plano em $M$. stenophylla). Com $M$. engleriana compartilha as folhas e ramos glabros e receptáculo campanulado, no entanto, se 


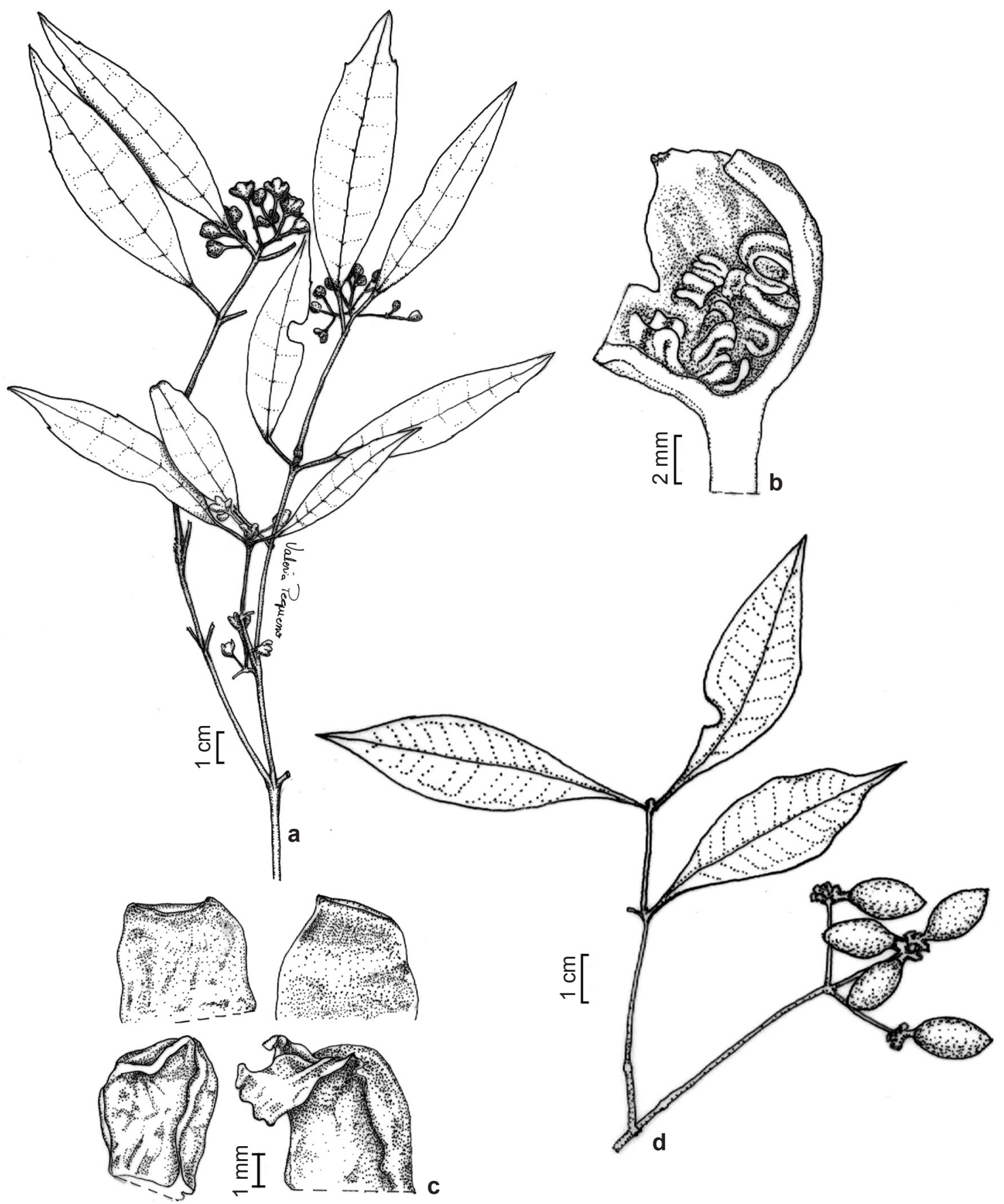

Figura 17 -a-c. Mollinedia sp. 3 -a. ramo com flores estaminadas em antese; b. flor estaminada em corte longitudinal; c. lobos da flor estaminada (superiores externos, inferiores internos). d. Mollinedia sp. 2 -ramo com drupéolas. (c. Kollmann 42518; d. Lopes 673). Ilustrações: Valéria Pequeno.

Figure 17 - a-c. Mollinedia sp. 3 - a. branch with staminate flowers in anthesis; b. staminate flower in longitudinal section; c. tepals of the staminate flower (superiors externals, inferiors internals). d. Mollinedia sp. 2 - branch with fruits. (c. Kollmann 42518; d. Lopes 673). Illustrations: Valéria Pequeno. 

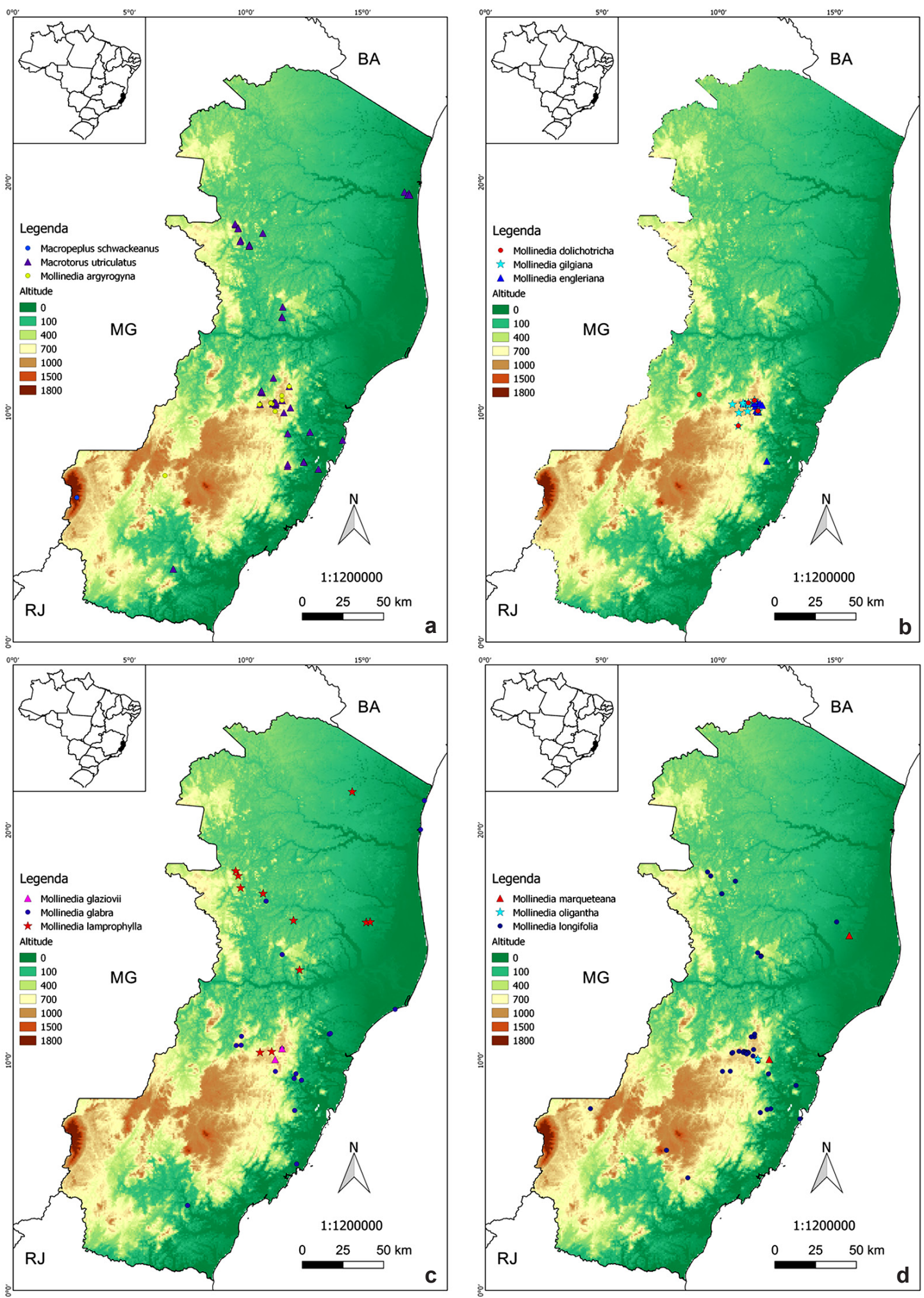

Figura 18 - Distribuição geográfica das espécies de Monimiaceae no Espírito Santo com camada altitudinal. Figure 18 - Geographic distribution of the species of Monimiaceae in Espírito Santo state with altitudinal layer. 

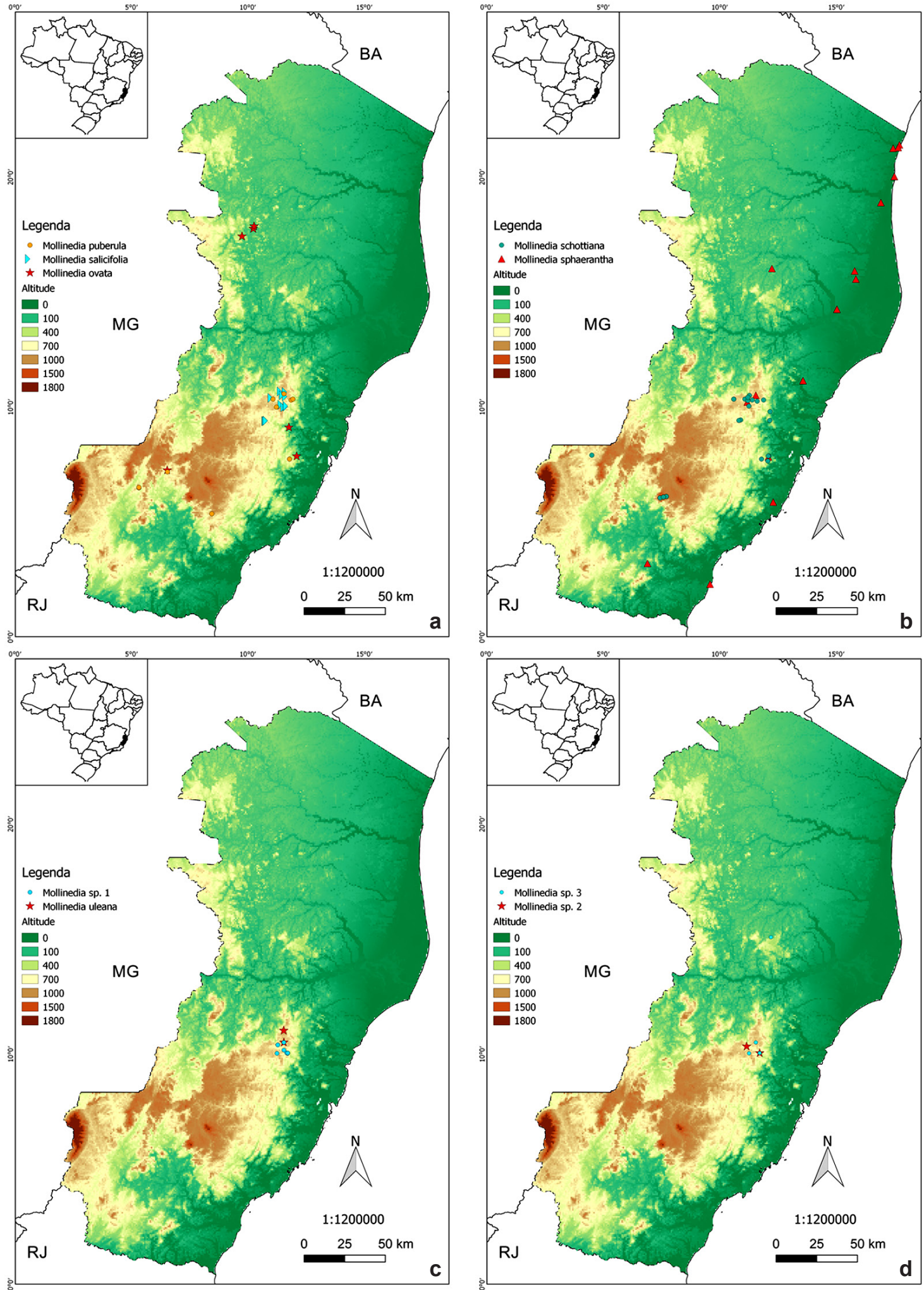

Figura 19 - Distribuição geográfica das espécies de Monimiaceae no Espírito Santo com camada altitudinal. Figure 19 - Geographic distribution of the species of Monimiaceae in the Espírito Santo state with altitudinal layer. 
diferencia pelas folhas marrons a oliváceas, com odor mentolado quando frescas, inflorescências esparso-pubérulas, flores alaranjadas e não carnosas quando frescas, drupéolas marrons, glabras (versus folhas enegrecidas, não odoríferas, inflorescências com pilosidade restrita às brácteas, flores amarelas e carnosas quando frescas, drupéolas enegrecidas, pubérulas). Ocorre no cume de encostas em Floresta Ombrófila Densa Montana. Coletada com flores em maio, junho e agosto e frutos em janeiro, março e agosto.

\section{Agradecimentos}

Aos curadores dos herbários visitados, em especial a Helio Q. Boudet Fernandes, curador do MBML, do Instituto Nacional da Mata Atlântica, por oferecer espaço para pesquisa e estudos na coleção durante toda a execução do trabalho. A Vinícius Lopes Aledi, Valderes Sarnaglia, Joelcio Freitas, Michel Ribeiro e Josiene Rossini, o apoio durante as coletas de campo. A Valéria Pequeno e Thelma Ratton, as ilustrações. A Tatiana Tavares Carrijo, Vidal de Freitas Mansano e Claudio Nicoletti Fraga, as valiosas sugestões e contribuições ao trabalho. À Capes, a concessão da bolsa de mestrado ao primeiro autor, e ao SISBIOTA-CNPq, o auxílio financeiro para as atividades de campo.

\section{Referências}

APG IV - The Angiosperm Phylogeny Group (2016) An update of the Angiosperm Phylogeny Group classification for the orders and families of flowering plants. Botanical Journal of the Linnean Society 181: $1-20$.

BFG - The Brazil Flora Group (2015) Growing knowledge: an overview of seed plant diversity in Brazil. Rodriguésia 66: 1085-1113.

Barroso GM, Morim MP, Peixoto AL \& Ichaso CLF (1999) Frutos e sementes: morfologia aplicada à sistemática de dicotiledôneas. Editora UFV, Viçosa. $443 p$.

Brasil (2006) O corredor central da mata atlântica: uma nova escala de conservação da biodiversidade. Ministério do Meio Ambiente, Conservação Internacional e Fundação SOS Mata Atlântica, Brasília. 46p.

Brown R (1814) General remarks, geographical and systematical, on the botany of Terra Australis. In: Flinders M (ed.) A voyage to terra australis. G \& W Nicol, London. Pp. 533-613.

Dutra VF, Alves-Araújo A \& Carrijo TT (2015) Angiosperm checklist of Espírito Santo: using electronic tools to improve the knowledge of an Atlantic Forest biodiversity hotspot. Rodriguésia 66: 1145-1152.
Endress PK (2010) Disentangling confusions in inflorescence morphology: patterns and diversity of reproductive shoot ramification in angiosperms. Journal of Systematics and Evolution 48: 225-239.

Garbin, ML, Saiter, FZ, Carrijo TT \& Peixoto AL (2017) Breve histórico e classificação da vegetação capixaba. Rodriguésia 68: 1883-1894.

Hencker C, Assis AM \& Lírio EJ (2012) Fitossociologia de um trecho de floresta estacional semidecidual no município de Itarana (ES). Natureza On line 10: 153-159.

Jussieu PMI (1809) Sur les Monimiées, nouvel ordre de plantes. Annales du Muséum National d'Histoire Naturelle 14: 133.

Gibbs LS (1917) A Contribution to the phytogeography and flora of the Arfak Mountains. Taylor \& Frances, London. 242p.

Gonzalez M (2007) Distribuição geográfica conhecida e potencial de Hennecartia omphalandra Poisson e Macropeplus ligustrinus (Tul.) Perkins (Monimiaceae). Dissertação de Mestrado. Escola Nacional de Botânica Tropical, Instituto de Pesquisas Jardim Botânico do Rio de Janeiro, Rio de Janeiro. 100p.

IPEMA - Instituto de Pesquisa da Mata Atlântica (2004) Conservação da Mata Atlântica no estado do Espírito Santo: cobertura florestal e unidades de conservação. Conservação Internacional do Brasil e IPEMA, Vitória. 112p.

Lani JL, Resende M, Rezende SB \& Feitosa LR (2008) Atlas dos ecossistemas do Espírito Santo. UFV, Viçosa. 504p.

Lírio EJ \& Peixoto AL (2015) A new species of Mollinedia (Monimiaceae, Mollinedioideae, Mollinedieae) from Atlantic Rainforest, Brazil. Phytotaxa 239: 89-95.

Lírio EJ, Peixoto AL \& Siqueira MF (2015) Taxonomy, conservation, geographic and potential distribution of Macrotorus Perkins (Mollinedioideae, Monimiaceae), and a key to the Neotropical genera of Monimiaceae. Phytotaxa 234: 201-214.

Lírio EJ, Freitas J, Negrão R, Martinelli G, \& Peixoto AL (2017) A hundred years' tale: rediscovery of Mollinedia stenophylla (Monimiaceae) in the Atlantic rainforest, Brazil. Oryx (first online): 1-5.

Peixoto AL (1979) Contribuição ao conhecimento da seção Exappendiculate Perkins do gênero Mollinedia Ruiz et Pavon (Mollinedieae, Monimioideae, Monimiaceae). Rodriguésia 50: 135-222.

Peixoto AL (1987) Revisão taxonômica do gênero Mollinedia Ruiz et Pavon (Monimiaceae, Monimioideae). Tese de Doutorado. Universidade Estadual de Campinas, Campinas. 392p.

Peixoto AL \& Gonzalez M (2009) Monimiaceae. In: Stehmann JR et al. (eds.) Plantas da Floresta Atlântica. Instituto de Pesquisas Jardim Botânico do Rio de Janeiro, Rio de Janeiro. 505p. 
Peixoto AL, Lírio EJ, Maurenza D, Reis-Júnior JS, Santos-Filho LAF, Abreu MB, Bovini MG \& Pietro PV (2013) Monimiaceae. In: Martinelli G \& Moraes MA (orgs.) Livro vermelho da flora do Brasil, Rio de Janeiro. Pp. 703-705.

Peixoto AL \& Pereira-Moura MVL (2008) A new genus of Monimiaceae from the Atlantic Coastal Forest in South-Eastern Brazil. Kew Bulletin 63: 137-141.

Peixoto AL, Pereira-Moura MVL \& Santos IS (2002) Monimiaceae. In: Wanderley MGL, Shepherd G \& Giulietti AM (orgs.) Flora fanerogâmica do estado de São Paulo. Instituto de botânica, São Paulo. Vol. 2, pp. 189-207.

Peixoto AL, Reitz R \& Guimarães EF (2001) Monimiaceae. In: Reis A (ed.) Flora ilustrada catarinense. Herbário Barbosa Rodrigues, Itajaí. Pp. 64.

Peixoto AL \& Santos IS (2011) Monimiaceae. In: Rizzo JA (org.) Flora dos estados de Goiás e Tocantins. FUNAPE, PRPPG/UFG, Goiânia. Pp. 34.

Perkins J (1900) Monographye der Gattung Mollinedia. Botanische Jahrbücher für Systematik, Pflanzengeschichte und Pflanzengeographie 27: 636-683.

Perkins J \& Gilg E (1901) Monimiaceae. In: Engler A. Das Pflanzenreich IV.101 (Heft 4): 1-122.

Philipson WR (1993) Monimiaceae. In: Kubitzki K, Rohwer JG \& Bittrich V (eds.) The families and genera of vascular plants. Flowering plants. Dicotyledons: magnoliid, hamamelid and caryophillid families. Vol. 2. Springer Verlag, Berlin. Pp. 426-437.

Pichon M (1948) Les Monimiacées, famille hétérogène. Bulletin du Muséum national d'histoire naturelle, sér. II, 20: 383-384.

Prance GT (1982) Forest refuges: evidence from woody angiosperms. In: Prance GT (ed.) Biological diversification in the tropics. Columbia University Press, New York. Pp. 137-158.

Radford AE, Dickison WC, Massey JM \& Bell CR (1974) Vascular plant systematics. Harper et Row, New York. 891p.

Reis JRM \& Fontoura T (2009) Diversidade de bromélias epífitas na Reserva Particular do Patrimônio Natural Serra do Teimoso - Jussari, BA. Biota Neotropica 9: 73-79.
Renner SS (1999) Circunscription and phylogeny of the Laurales: evidence from molecular and morphological data. American Journal of Botany 86: 1301-1315.

Renner SS \& Chanderbali AS (2000) What is the relationships among Hernandiaceae, Lauraceae, and Monimiaceae, and why is this question so difficult to answer? International Journal of Plant Sciences 161: 109-119.

Renner SS, Strijk JS, Strasberg D \& Thébaud C (2010) Biogeography of the Monimiaceae (Laurales): a role for East Gondwana and long-distance dispersal, but not West Gondwana. Journal of Biogeography 37: 1227-1238.

Romanov MS, Endress PK, Bobrov AVF, Melikian AP \& Bejerano AP (2007) Fruit and systematics of Monimiaceae s.s. (Laurales). Botanical Journal of the Linnean Society 153: 265-285.

Ruiz LH \& Pavón JA (1794) Florae Peruvianae, et Chilensis Prodromus. De Sancha, Madrid. Pp. 153.

Saiter FZ, Guilherme FAG, Thomaz LD \& Wendt T (2011) Tree changes in a mature rainforest with high diversity and endemism on the Brazilian coast. Biodiversity and Conservation 20: 1921-1949.

Santos IS \& Peixoto AL (2001) Taxonomia do gênero Macropeplus Perkins (Monimiaceae, Monimioideae). Rodriguésia 52: 65-105.

Schodde R (1970) Two new suprageneric taxa in the Monimiaceae alliance (Laurales). Taxon 19: 324328.

Stern WT (2004) Botanical latin. $4^{\mathrm{a}}$ ed. Timber Press, Portland. 566p.

Thiers B [continuamente atualizado] Index Herbariorum: a global directory of public herbaria and associated staff. New York Botanical Garden's Virtual Herbarium. Disponível em $<$ http://sweetgum.nybg. org/science/ih/>. Acesso em 6 maio 2017.

Thomaz LD \& Monteiro R (1997) Composição florística da Mata Atlântica de encosta da Estação Biológica Santa Lúcia, município de Santa Teresa, ES. Boletim do Museu de Biologia Mello Leitão 7: 1-48.

Tulasne LR (1857) Monimiaceae. In: Martius CFP von, Eichler AW \& Urban I. Flora brasiliensis. Leipzig, Munchen, Wien. Vol. 3, pp. 290-327.

Willard W (1978) A glossary of plant hair terminology. Brittonia 30: 239-255. 


\section{Lista de exsicatas}

Amorim A 5673 (3.2). Amorim AM 7155 (3.14), 7573 (3.8), 7584 (3.12), 7614 (3.11). Araújo EA 444 (1.1), 445 (1.1). Assis A 754 (3.5), 1085 (3.5), 3193 (2.1), 3239 (3.5), 3251 (2.1). Boone W 39 (3.17), 584 (3.8), 643 (3.8). Braga JMA 1631 (3.4). Britto R 69 (3.16). Carrijo T 1970 (3.14). Carvalho GM 161 (3.5). Cruz TA 22 (3.1), 23 (3.4), 102 (3.4), 103 (2.2), 113 (3.6). Demuner V 147 (3.4), 229 (2.1.), 270 (3.18), 291 (3.8), 304 (3.14), 599 (3.19), 605 (3.17), 718 (3.17), 764 (3.5), $786(3.4), 838$ (3.8), 931 (3.5), 1188 (3.5), 1213 (3.17), 1378 (3.18), 1384 (3.12), 1437 (3.4), 1447 (2.1), 1726 (2.1), 1846 (3.5), 1972 (3.11), 2349 (3.8), 2436 (2.1), 2486 (3.7), 2505 (3.5), 2516 (3.5), 2573 (3.5), 2642 (3.8), 2828 (2.1), 3256 (3.5), 3353 (2.1), 4024 (2.1). Dias HM 815 (3.10). Fernandes HQB 1326 (2.1). Flores TB 971 (3.8). Folli DA 547 (3.9), 3718 (3.5), 3812 (3.15), 3955 (3.15), 4127 (3.15), 4916 (3.15), 4948 (3.15), 5096 (3.7), 5645 (3.15), 6418 (3.8), 6497 (3.9), 6608 (3.9), 6706 (3.4). Fontana AP 128 (3.14), 131 (3.12), 1499 (3.8), 2857 (3.8), 3228 (3.15), 5396 (3.14). Forzza RC 5249 (2.1). Fraga CN 1849 (2.1), 2159 (3.14), 2184 (3.8), 2187 (3.3), 2291 (3.15). Freire GQ 151 (3.7). Goldenberg R 1274 (3.14). Hatschbach G 46881 (3.18), 48618 (3.12), 49911 (3.12), 49932 (2.1.). Hofmann WA 143 (3.12). Klein VL 925 (3.1). Kollmann L 144 (2.1), 183 (3.9), 267 (3.4), 333 (3.14), 441 (3.8), 501 (3.1), 904 (3.12), 1112 (3.17), 1323 (3.4), 1330 (3.4), 1343 (3.1), 1373 (3.8), 1496 (2.1), 1510 (3.2), 1676 (3.14), 1680 (3.14), 1715 (3.4), 1740 (3.16) 1745 (3.14), 1747 (3.1), 1835 (3.17), 2021 (3.8), 2302 (3.19), 2489 (3.3), 2561 (3.17), 2595 (2.1.), 2606 (3.14), 2627 (2.1), 2643 (3.8), 2646 (2.1), 2651 (3.8), 4251 (3.19), 4479 (3.14), 4497 (3.3), 4685 (3.3), 4813 (3.13), 5052 (2.1), 5433 (3.5), 5489 (3.4), 5653 (3.1), 5995 (3.8), 6756 (3.14), 6892 (3.4), 6911 (3.8), 6912 (3.8), 6915 (3.19), 6916 (3.19), 6917 (3.17), 6918 (3.13), 6921 (3.17), 6931 (3.4), 6939 (3.8), 6945 (2.1), 6947 (3.14), 6952 (3.8), 6958 (3.7), 7149 (3.5), 7209 (3.14), 7499 (3.8), 7917 (3.14), 7968 (3.14), 8158 (3.8), $8684(3.8), 8694(3.8)$, 9079 (2.1), 9440 (3.14), 9460 (3.8), 9737 (3.15), 10332 (3.15), 9440 (3.14), 10561 (3.14), 10562 (3.14), 11521 (3.8). Kuhlmann JG 153 (3.7). Labiak P 5180 (3.14). Lima HC 3534 (3.6). Lírio EJ 19 (3.2), 20 (3.19), 21 (3.17), 23 (3.17), 27 (3.2), 28 (2.1), 32 (3.17), 33 (3.17), 34 (3.17), 35 (3.14), 36 (3.17), 37 (3.19), 38 (3.4), 39 (3.2), $40(3.4), 41(3.4), 42(3.4), 43(3.4), 45(3.10), 46(3.3), 47(3.3)$, 48 (3.4), 53 (3.17), 55 (3.4), 56 (3.15), 57 (3.4), 58 (3.17), 59 (3.17), 71 (3.8), 72 (3.8), 84 (3.15), 86 (3.15), 88 (3.15), 93 (3.13), 105 (3.11), $106(3.11), 109(3.11), 111(3.12), 114(3.11), 115(3.8), 117(3.11), 122(3.11), 124(3.11), 129(3.15), 131(3.4), 133(3.11), 162$ (2.1), 167 (3.15), 174 (3.15), 176 (3.15), 180 (3.8), 183 (3.8), 185 (3.4), $186(3.17), 187(3.4), 190(3.3), 192(3.8), 200(3.8), 201(3.8)$, 203 (3.15), 206 (3.8), 209 (3.4), 223 (3.7), 223 (3.5), 224 (3.5), 229 (3.12), 452 (3.5), $1116(3.9), 1121(3.4), 1122(3.7), 1123(3.15)$, 1124 (3.15), 1125 (3.15), $1126(3.15), 1127$ (3.15), 1135 (3.15), 1137 (3.15), $1170(3.15), 1172(3.15), 1267(3.15), 1263(3.15), 1268$ (3.15), 1270 (3.15), 1173 (3.15), 1279 (3.15), 1281 (3.8), 1283 (3.8), 1284 (3.14), 1292 (3.5), 1295 (3.15), 1298 (3.15), 1300 (3.15), 1301 (3.15), 1302 (3.15), 1303 (3.15), 1304 (3.15), 1313 (3.15), 1314 (3.17), 1315 (3.17), 1350 (3.15), 1389 (3.5). Lopes WP 747 (3.4). Lopes JC 293 (3.15), 673 (3.18), 767 (3.19). Magnago LFS 522 (3.11), 642 (3.8), 1146 (2.1), 1148 (3.8), 1150 (2.1), 1235 (3.8), 1276 (3.11), 1318 (2.1), 1323 (3.7), 1367 (3.8), 1685 (3.5). Martinelli G 11902 (3.6), 12224 (3.7). Oliveira RP 870 (3.17). Peixoto AL 1435 (3.9), 3213 (3.9), 3349 (3.9), 3477 (3.4). Pereira OJ 3449 (3.5). Pizziolo W 316 (3.14). Rossini J 347 (3.3), 350 (3.12), 439 (3.3), 460 (3.18). Santos MF (MBML 4985) (2.1.). Saavedra M 740 (3.14). Schwacke RB 42511(1.1), 12353 (1.1). Siqueira G 791 (3.11). Souza MC 359 (3.17). Thomas WW 12658 (3.11). Thomaz LD 1044 (3.4), 1143 (3.4), 1144 (3.4), 1137 (3.4), 1273 (3.2), 1655 (3.13), 1656 (3.19), 1659 (3.2), 1660 (3.17). Vervloet RR 319 (3.4), 477 (2.1), 494 (3.4), 646 (3.15), 1002 (3.13), 1054 (3.3), 1305 (3.4), 1330 (3.17), 1340 (3.3), 1373 (3.6), 1420 (3.2), 1561 (3.17), 1710 (3.3), 1805 (3.4), 1822 (3.4), 1861 (3.4), 1936 (3.19), 1953 (3.2), 1963 (3.4), 1992 (3.13), 1994 (3.17), 2066 (3.13), 2083 (3.4), 2106 (2.1), 2174 (3.12), 2338 (3.3), 2364 (3.4), 2541 (3.15) 2798 (3.7), 2825 (2.1), 2828 (3.8), 2877 (3.11), 2923 (3.5), 3132 (3.19), 3181 (2.1), 3499 (3.8). Vimercat JM 156 (3.8). 
